\title{
La muerte es parte de la vida
}



Universidad Nacional Autónoma de México Facultad de Estudios Superiores Zaragoza Academia de Extensión Universitaria y Difusión de la Cultura
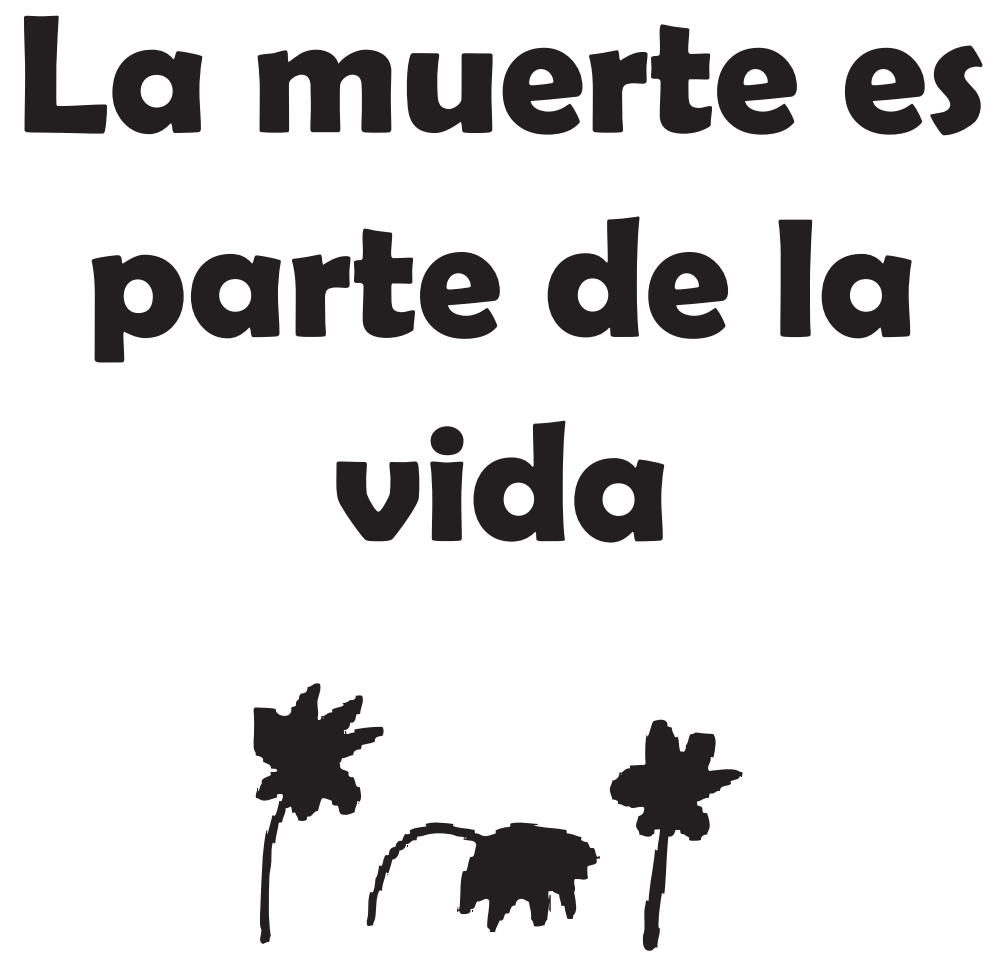

Imelda Ana Rodríguez Ortiz Mariana G. Cisneros Pelcastre Ana Lilia Vásquez Rodríguez

Febrero de 2010 


\section{LA MUERTE ES PARTE DE LA VIDA}

Imelda Ana Rodríguez Ortiz

Mariana G. Cisneros Pelcastre

Ana Lilia Vásquez Rodríguez

Edición y contenidos: Imelda Ana Rodríguez Ortiz

Ilustraciones: Mariana G. Cisneros Pelcastre

Contenidos: Ana Lilia Vásquez Rodríguez

Asesoría: Ernesto Durand Rodríguez e Ixchel Rosas Zárate

Diseño Editorial: Ricardo S. Galván Sánchez

Portada: Mariana G. Cisneros Pelcastre y Ricardo S. Galván Sánchez

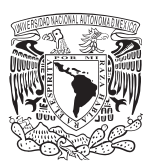

Universidad Nacional Autónoma de México

Facultad de Estudios Superiores Zaragoza

Academia de Extensión Universitaria y Difusión de la Cultura

Primera edición: Febrero de 2010

Impreso y hecho en México

ISBN 978-607-02-1430-1 


\section{Introducción}

Este es un libro para compartir entre familiares y amigos. Tiene como propósito reflexionar acerca del origen natural de la vida y los procesos que la constituyen: nacimiento, desarrollo, transformación y muerte. Hemos producido un material dirigido especialmente a los niños que les gusta leer, dibujar, colorear, pegar y recortar imágenes y textos.

Estamos convencidos de que estas actividades son muy creativas y necesarias para construir la propia versión de una historia importante y significativa, pero además, son actividades que los niños realizan cotidianamente como una forma de aprendizaje y apropiación de la realidad.

El libro está dividido en cuatro secciones que conviene trabajar en el orden que se presentan. Asimismo, hemos incluido dos anexos, el primero está constituido por lecturas diversas: cuentos, poemas, adivinanzas, coplas, refranes, canciones, fábulas, rimas y rondas y, el anexo 2, está dedicado a los adultos; contiene algunas reflexiones acerca de los niños y la capacidad que tienen para simbolizar y significar experiencias de dolor o pérdida.

Finalmente, sugerimos una serie de títulos de libros que pueden contribuir a enriquecer cada una de las secciones que conforman este libro. 


\section{Mi Libro}

Este libro fue diseñado especialmente para ti, empieza por presentarte y hacerlo tuyo. Recuerda que estarás trabajando con él durante algún tiempo, así que puedes decorarlo con cualquier clase de imágenes, recortes, fotografías o dibujos.

A lo largo de este libro encontrarás un sinfín de dibujos, todos están hechos para que tú les pongas color, puedes utilizar la técnica que prefieras: colores de madera, crayolas, pinturas o acuarelas.

También encontrarás señalamientos diferentes que te indicarán la actividad que tienes que realizar, así como instrucciones específicas para cada ejercicio.

ESCRIBE

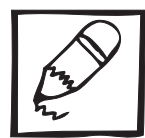

RECORTA

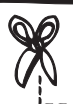

PEGA

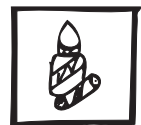


Mi nombre es

y tengo

años.

Mi escuela se llama

Voy en

grado.

Mi mejor amigo o amiga se llama

Lo que más me gusta hacer

Lo que más me molesta

Mi color favorito es el

El familiar con el que más me gusta estar se

llama

porque juntos podemos 


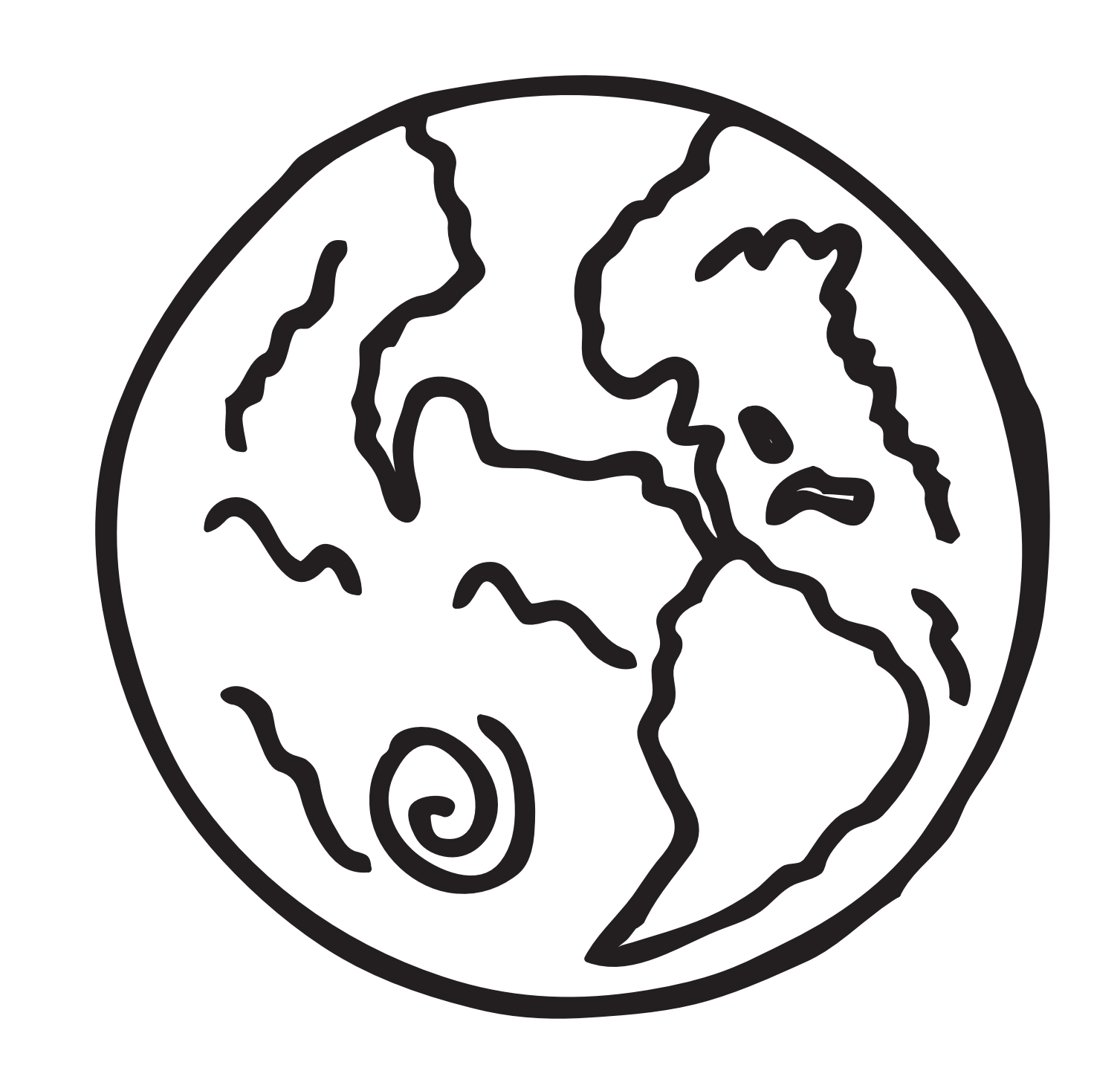




\section{Todo tiene un origen}

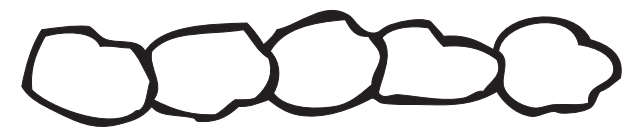

Los seres vivos habitamos el planeta Tierra, que forma parte del sistema solar. A su vez, el sistema solar forma parte de una galaxia que lleva por nombre La Vía Láctea.

Una galaxia está formada por gas, polvo, planetas y miles de millones de estrellas, como las que vemos brillar por las noches. El conjunto de galaxias constituye lo que se denomina Universo o Cosmos. A pesar de las investigaciones de los científicos para saber si existen seres vivos en ésta y en otras galaxias, con certeza sólo sabemos que los hay en la Tierra.

Los seres humanos hemos explorado casi la totalidad de nuestro planeta. El desarrollo de las ciencias ha favorecido nuestro entendimiento de la naturaleza $y$, en muchos casos, ha mejorado nuestras vidas. 


\section{¿Cómo se formó el universo?}
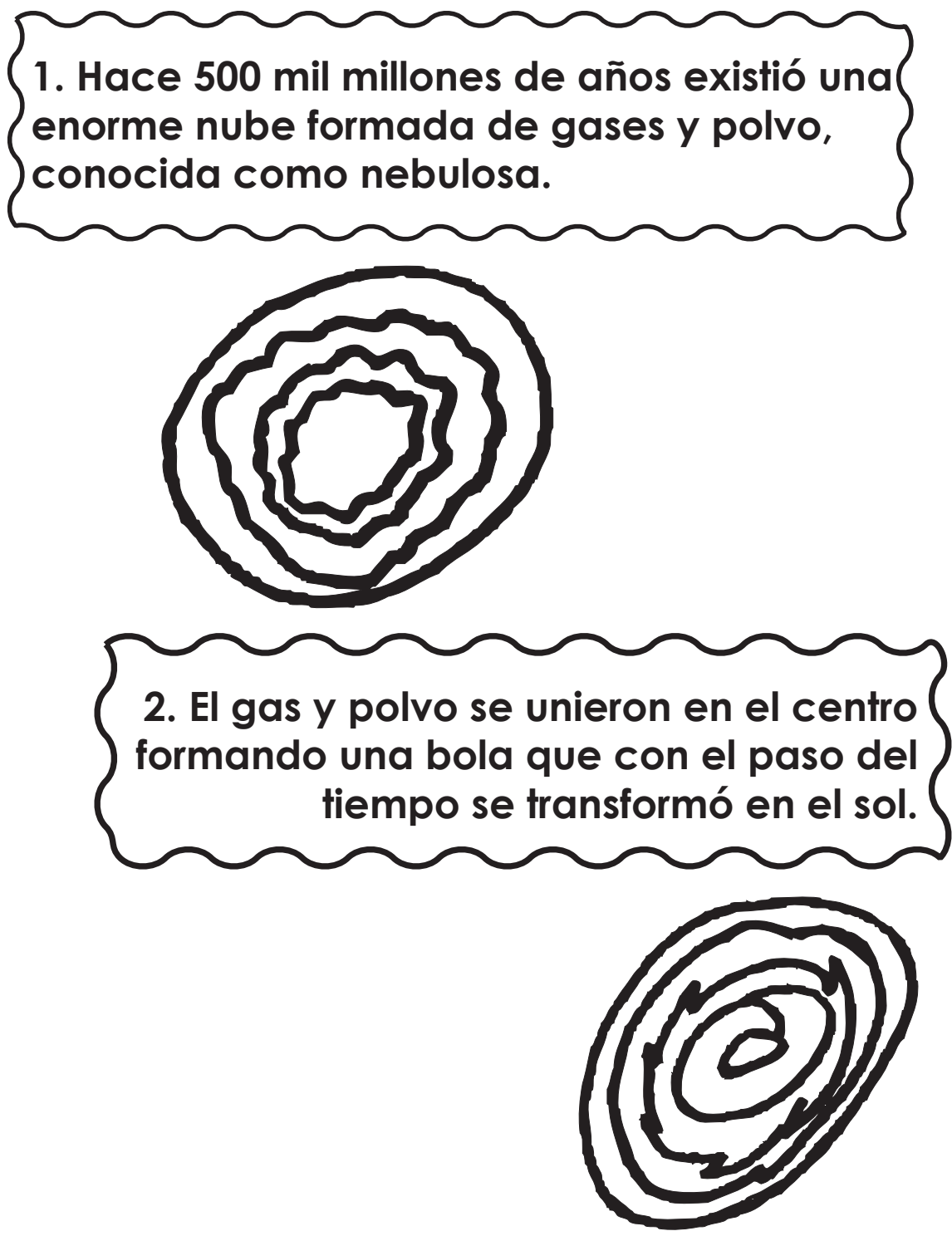

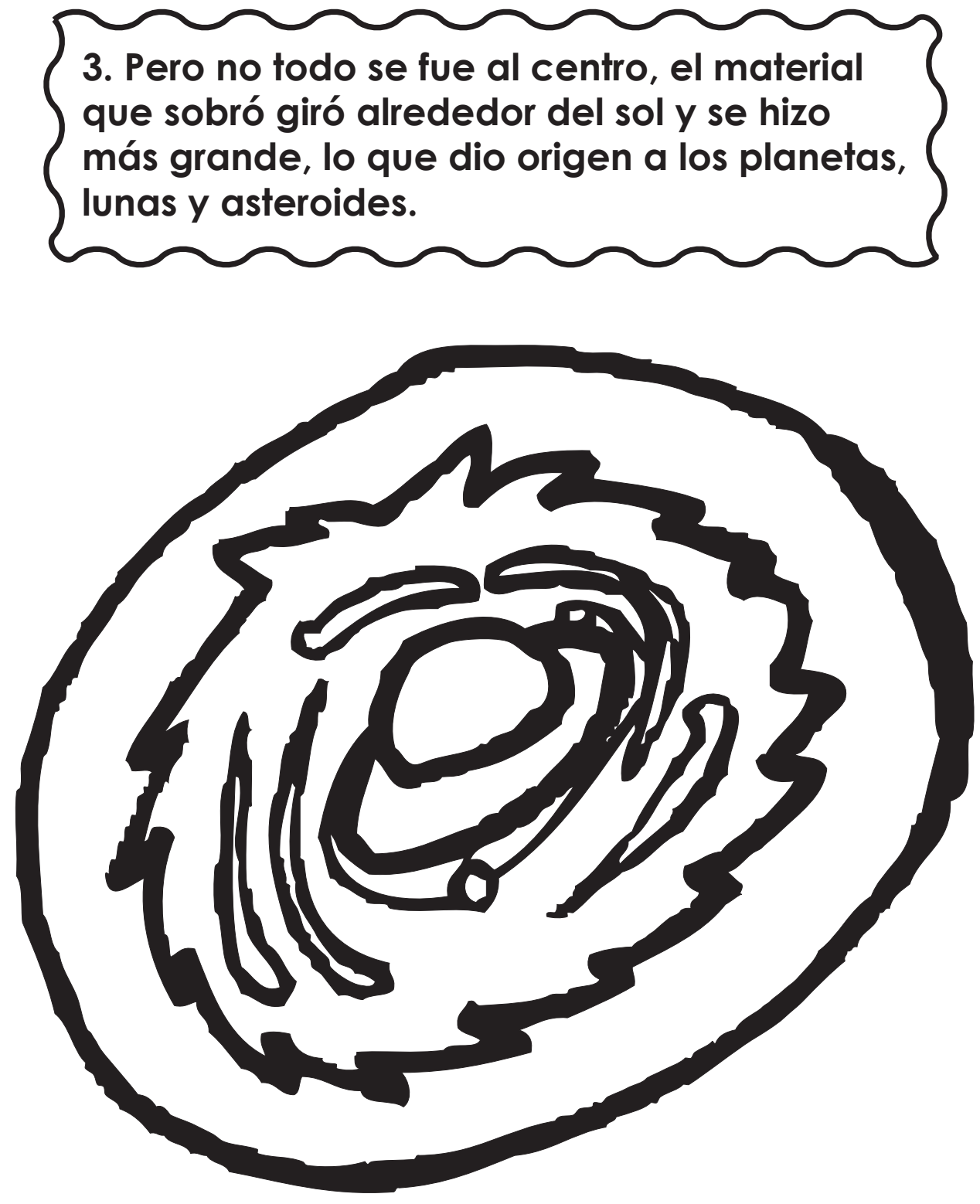


\section{¿Cómo se formó el planeta Tierra?}

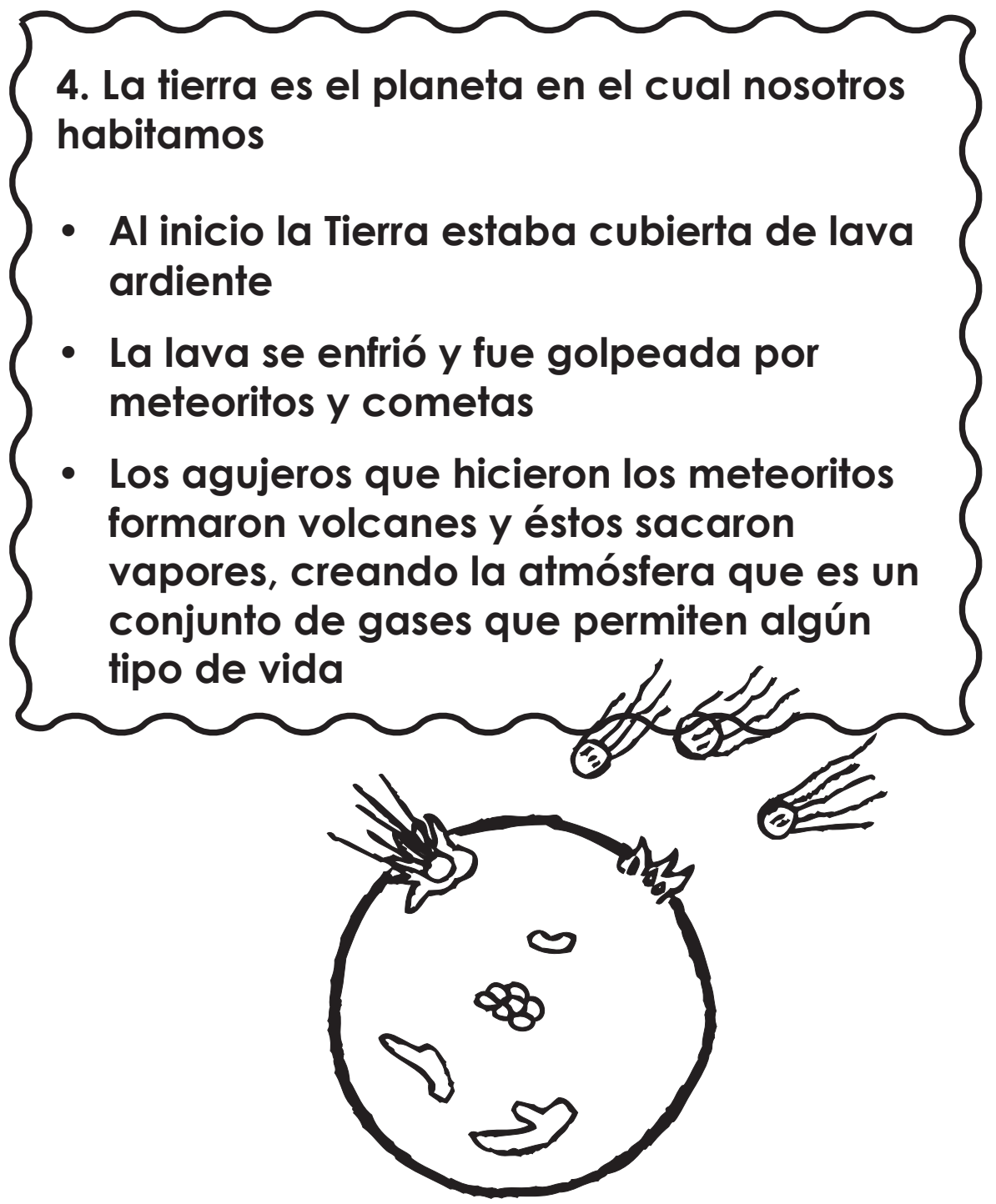



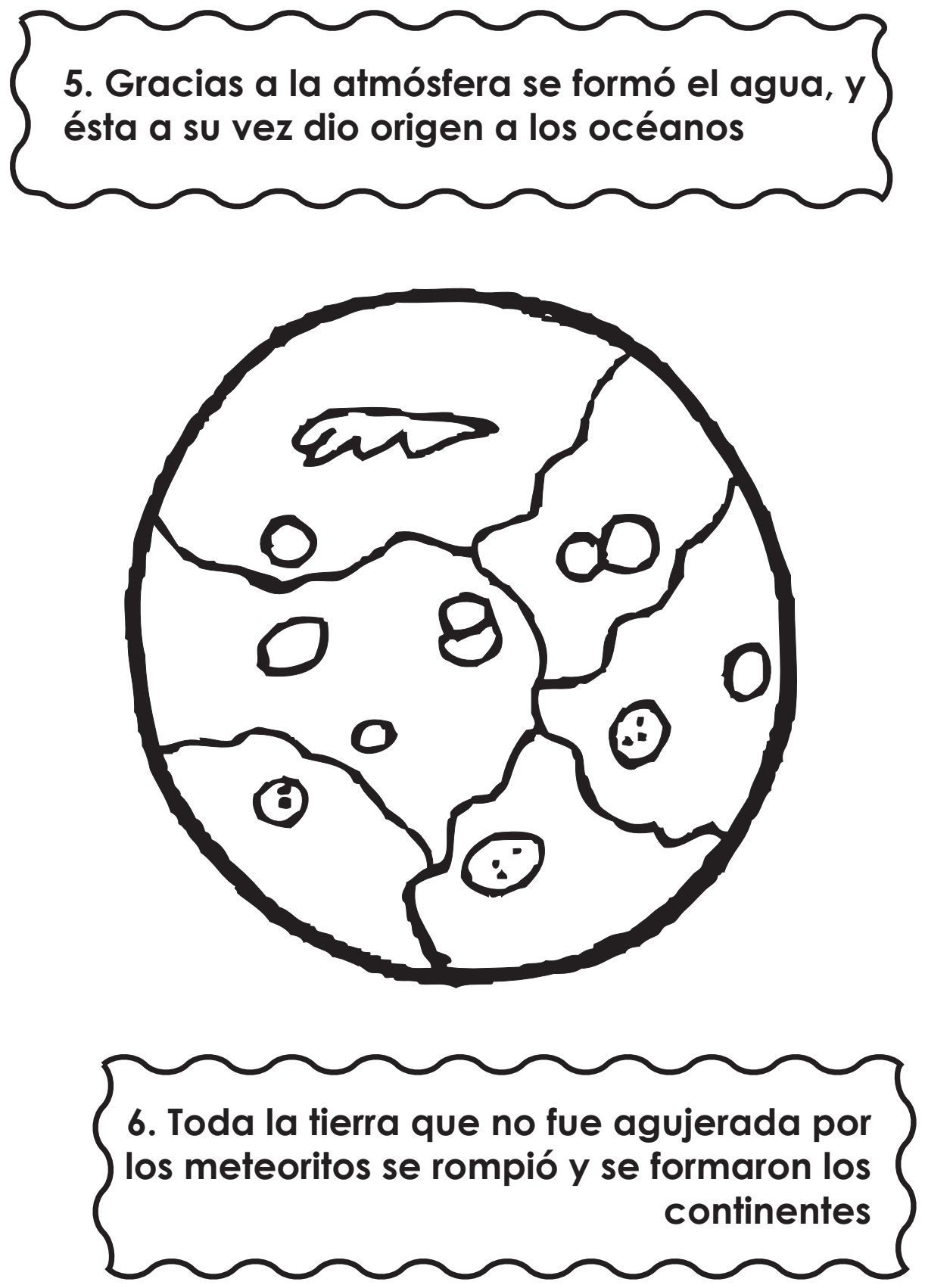


\section{Receta para el origen de la vida}

Ingredientes:

- Atmósfera adecuada

- Temperatura alta

- Elementos como: nitrógeno, carbono, hidrógeno y oxígeno

- Tormentas eléctricas

- Lluvias torrenciales

- Lava (para modificar la presión)

Modo de preparación:

- Mezclar todos los ingredientes y agregar sal al gusto

- Dejar enfriar 4000 millones de años 


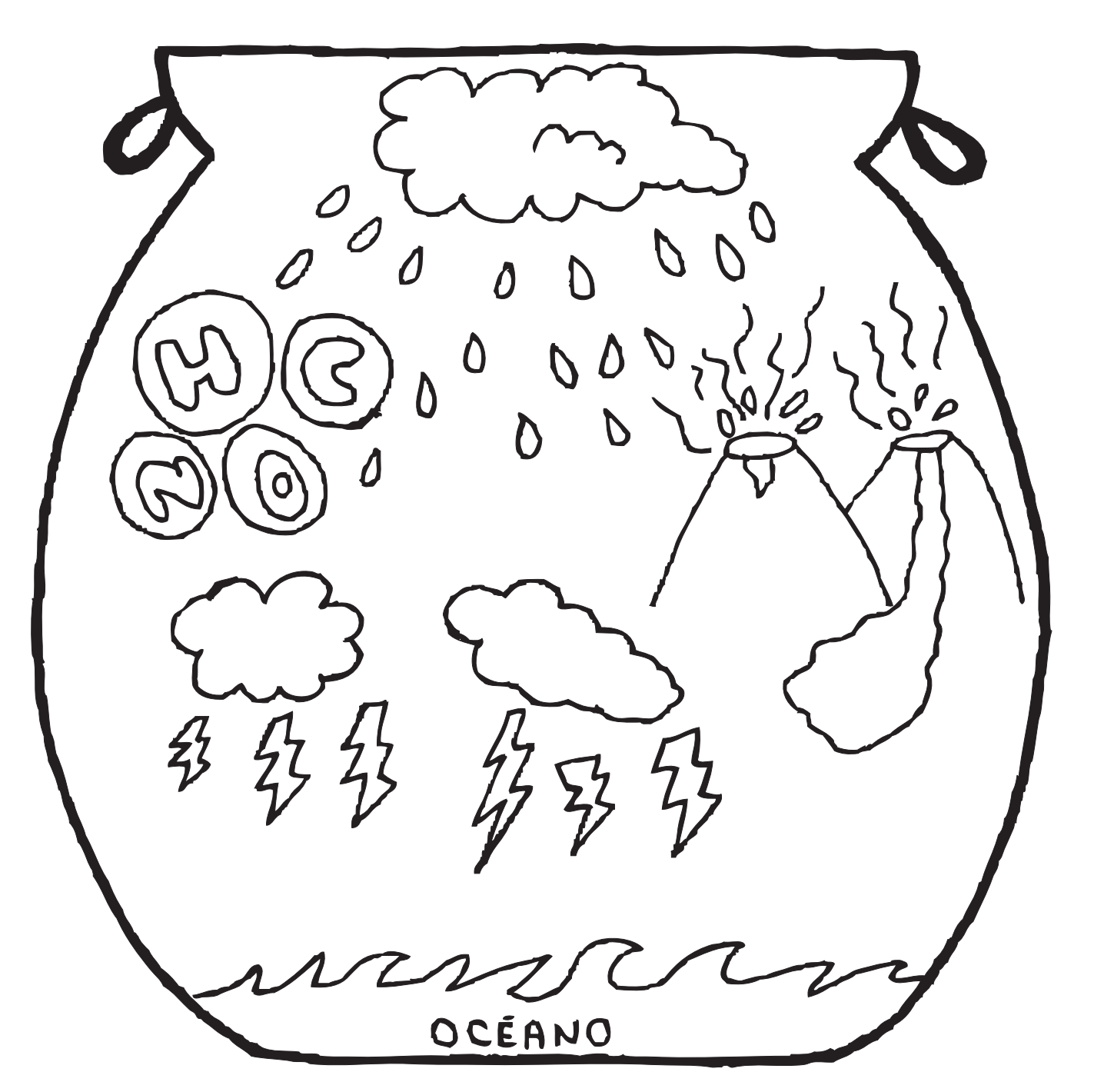




\section{Primeras formas de vida}

Con el paso del tiempo y gracias a las condiciones ambientales adecuadas de la Tierra y a la formación del océano primitivo, la vida se originó en el agua.

Se formaron las bacterias, organismos unicelulares y poco después los organismos pluricelulares (ej. plantas, animales, insectos), dando paso a una constante evolución de los seres vivos.

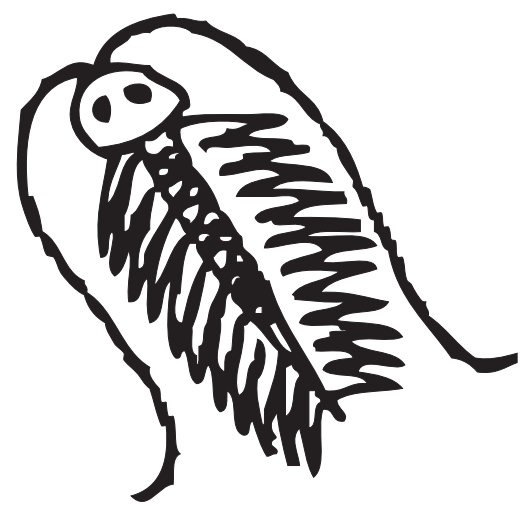



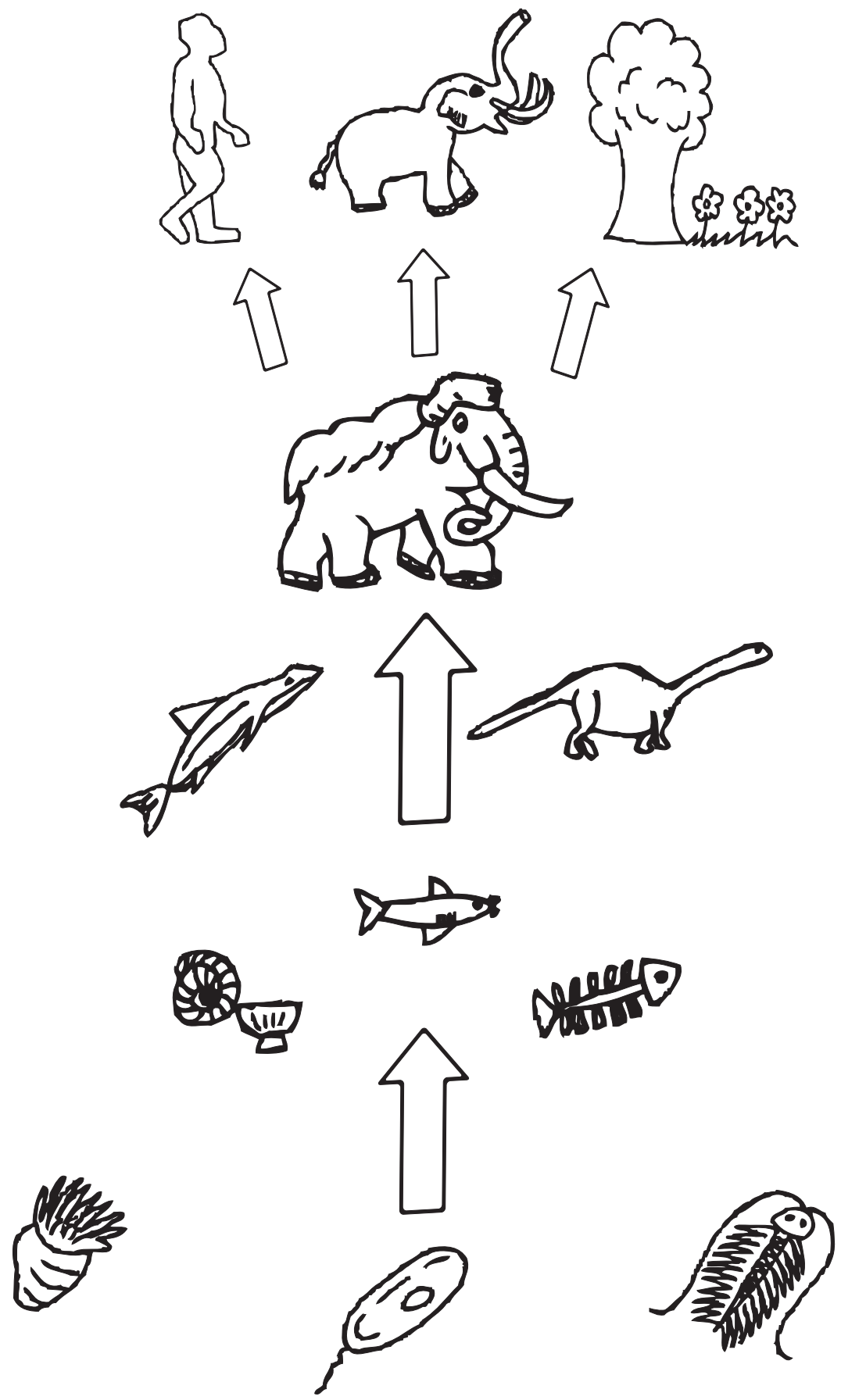

17 


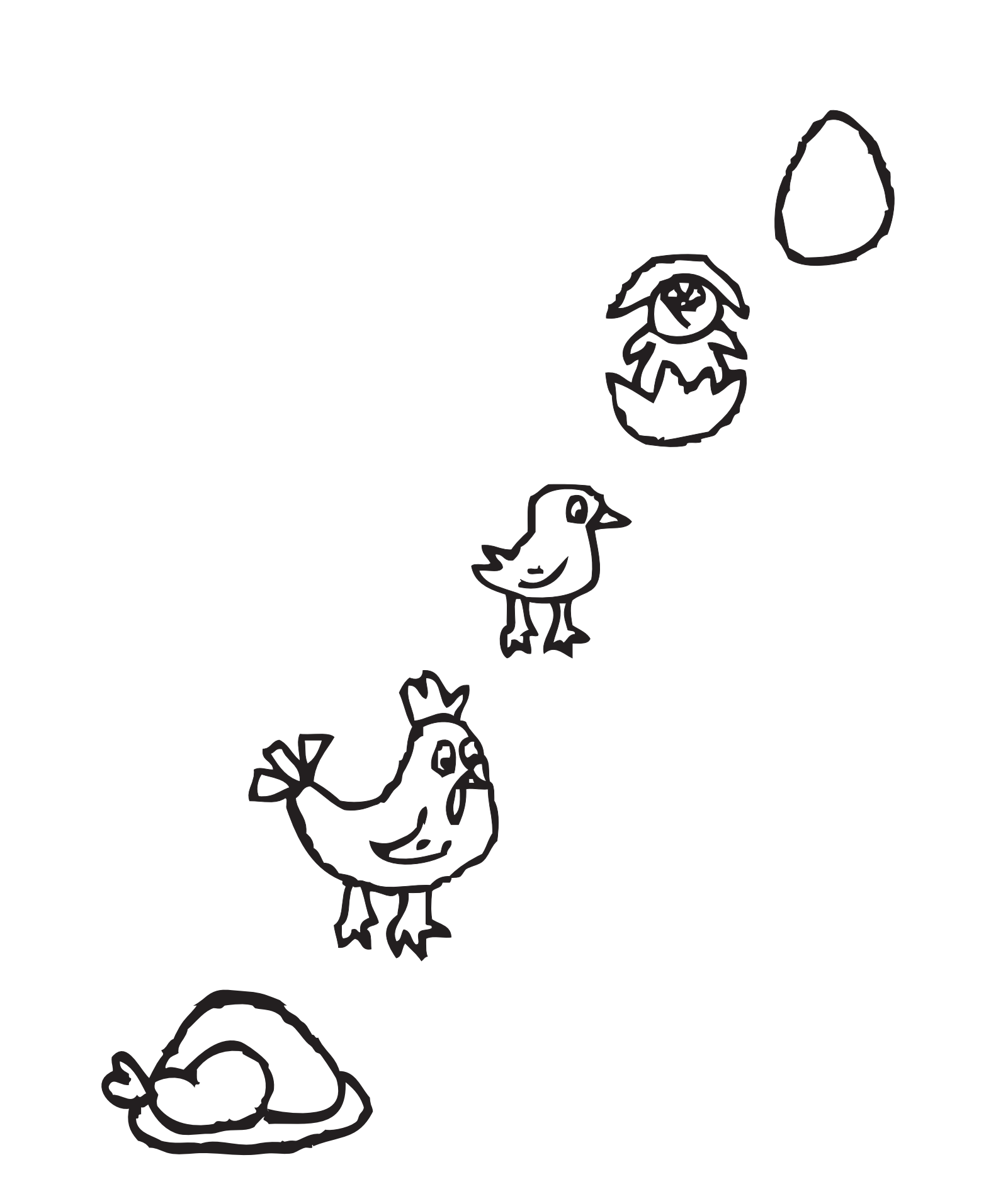




\section{Todo lo vivo sigue un ciclo}

El desarrollo de la vida se lleva a cabo gracias a los ciclos naturales y a los ciclos creados por el hombre.

Existen ciclos naturales largos como las estaciones del año y cortos como la duración del día y la noche.

Dentro de los ciclos creados por el hombre podemos encontrar, por ejemplo, la medición del tiempo, que nos ayuda a saber cuándo es nuestro cumpleaños, a qué hora salimos al recreo, entre muchas otras cosas. 


\section{Ciclo Natural: la vida de}

una mariposa

1

2

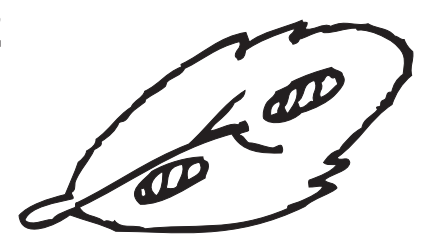

Se forman larvas

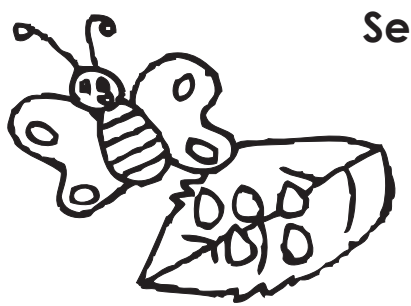

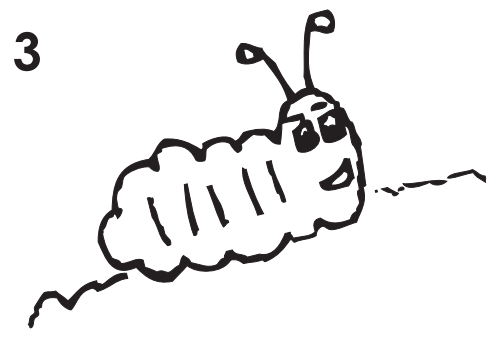

...gusanos

Mami pone huevos

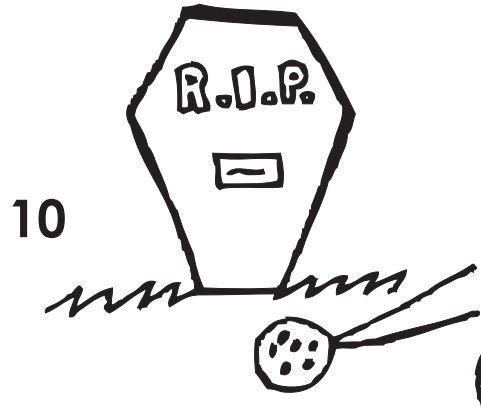

Las mariposas que mueren ayudan a la nutrición de las plantas que alimentarán a las larvas para que el ciclo comience de nuevo

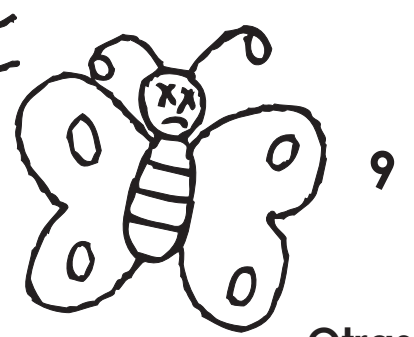

Otras envejecen y mueren

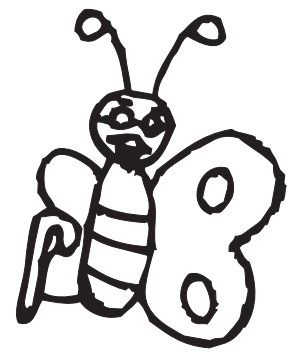

0 


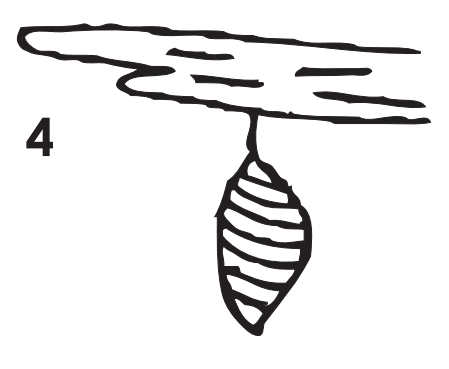

...capullos

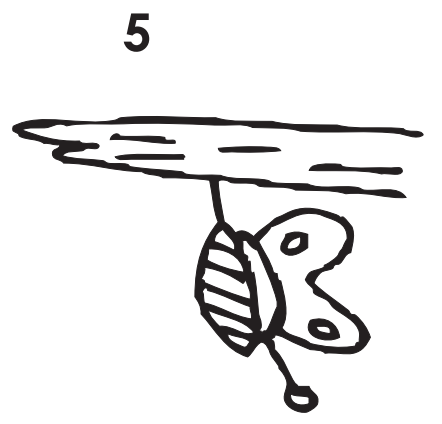

...mariposas
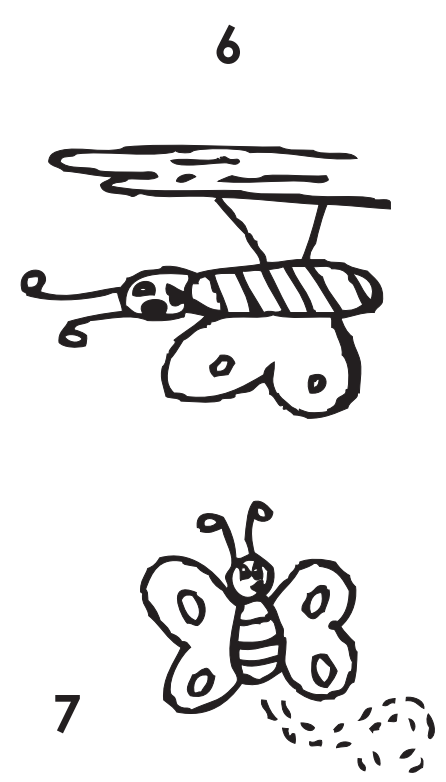

Durante el crecimiento y desarrollo se forman grupos, se relacionan y alcanzan metas

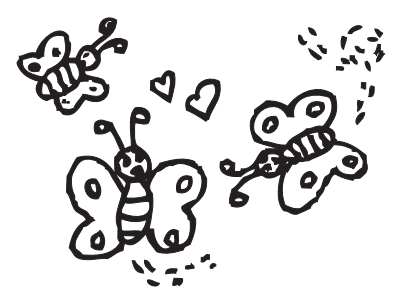

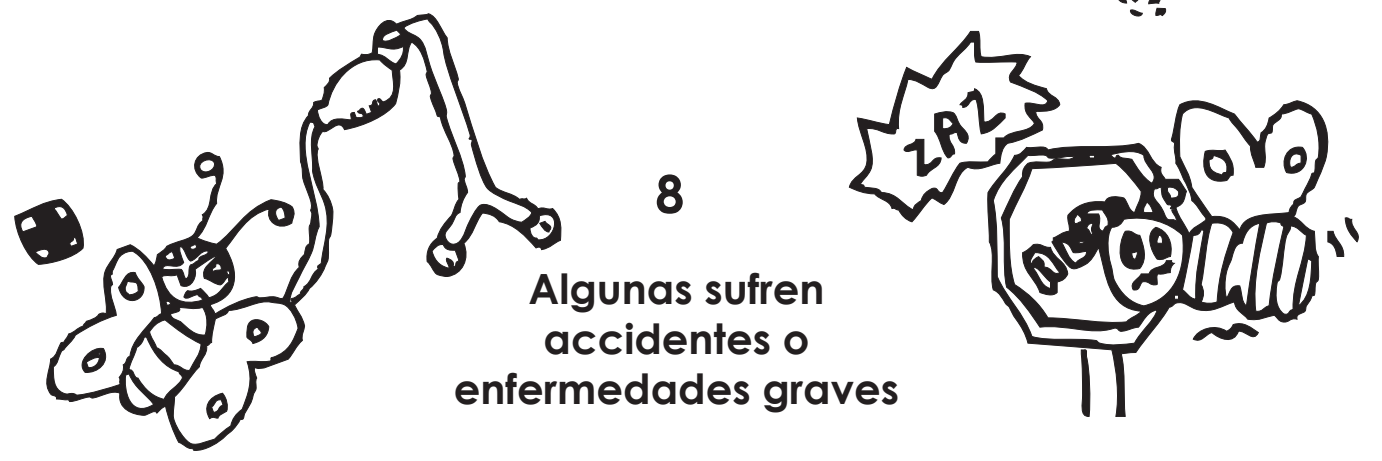




\section{Recuerda que todo lo vivo :}

Nace

Todos los organismos como, las plantas, animales y el ser humano tienen un cuerpo.
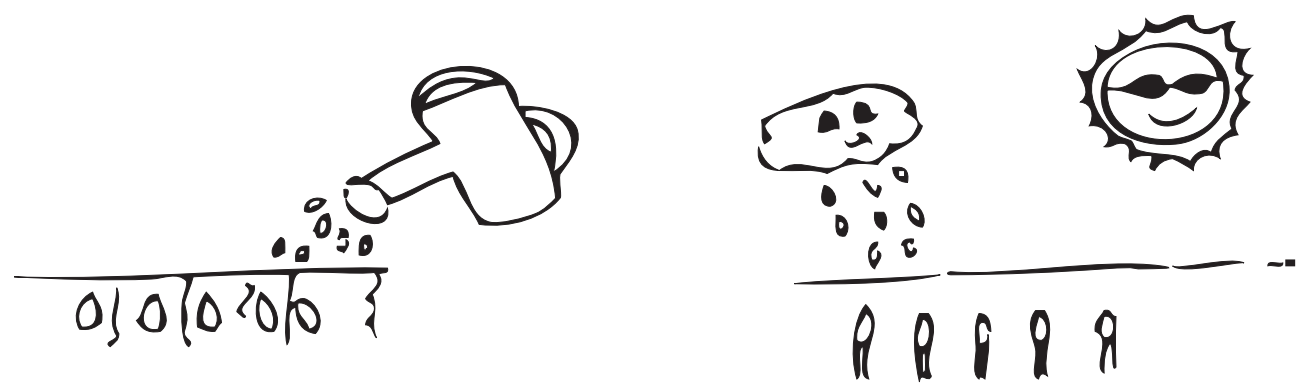

Se transforma

Debido a la relación que el cuerpo tiene con el ambiente, éste se transforma para que el organismo pueda adaptarse.
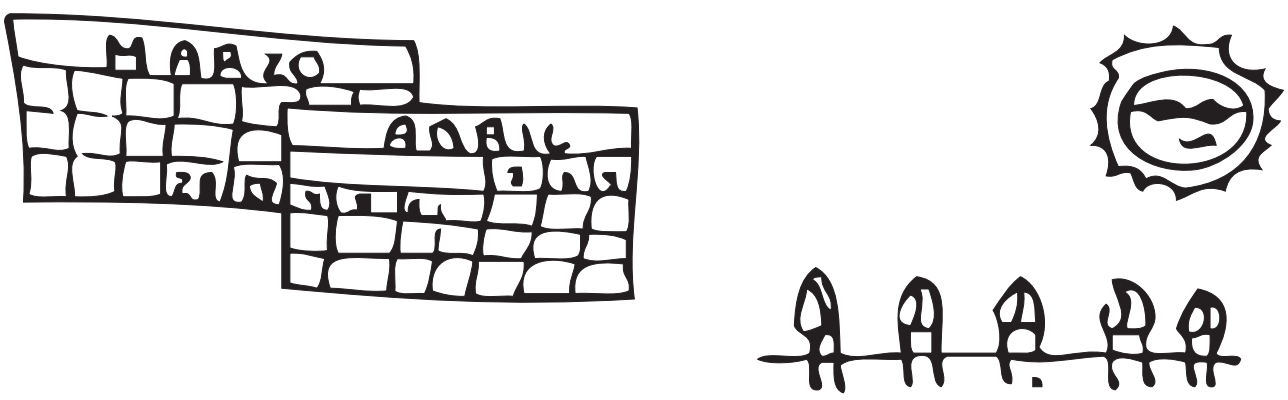
Se mueve

Los organismos tienen movimientos que los ayudan a sobrevivir. En el caso de los humanos existen los movimientos voluntarios, como jugar, correr o aplaudir. También existen movimientos involuntarios como respirar, parpadear o el latido de nuestro corazón.

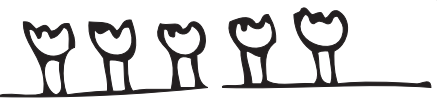

\section{Muere}
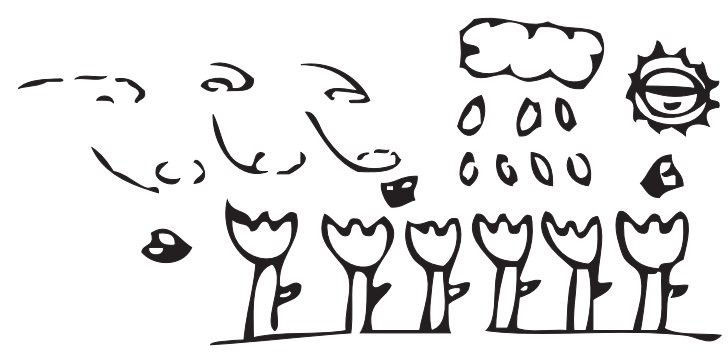

Es la última etapa de la vida, en el caso de los seres humanos es cuando dejamos de pensar, de sentir, de respirar y de hacer cualquier cosa que antes hacíamos. Nuestro cuerpo tiene los últimos cambios, todos ellos inevitables y naturales.

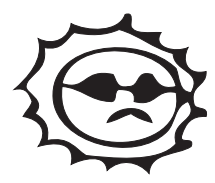




\section{Ciclo natural: el ciclo del agua}

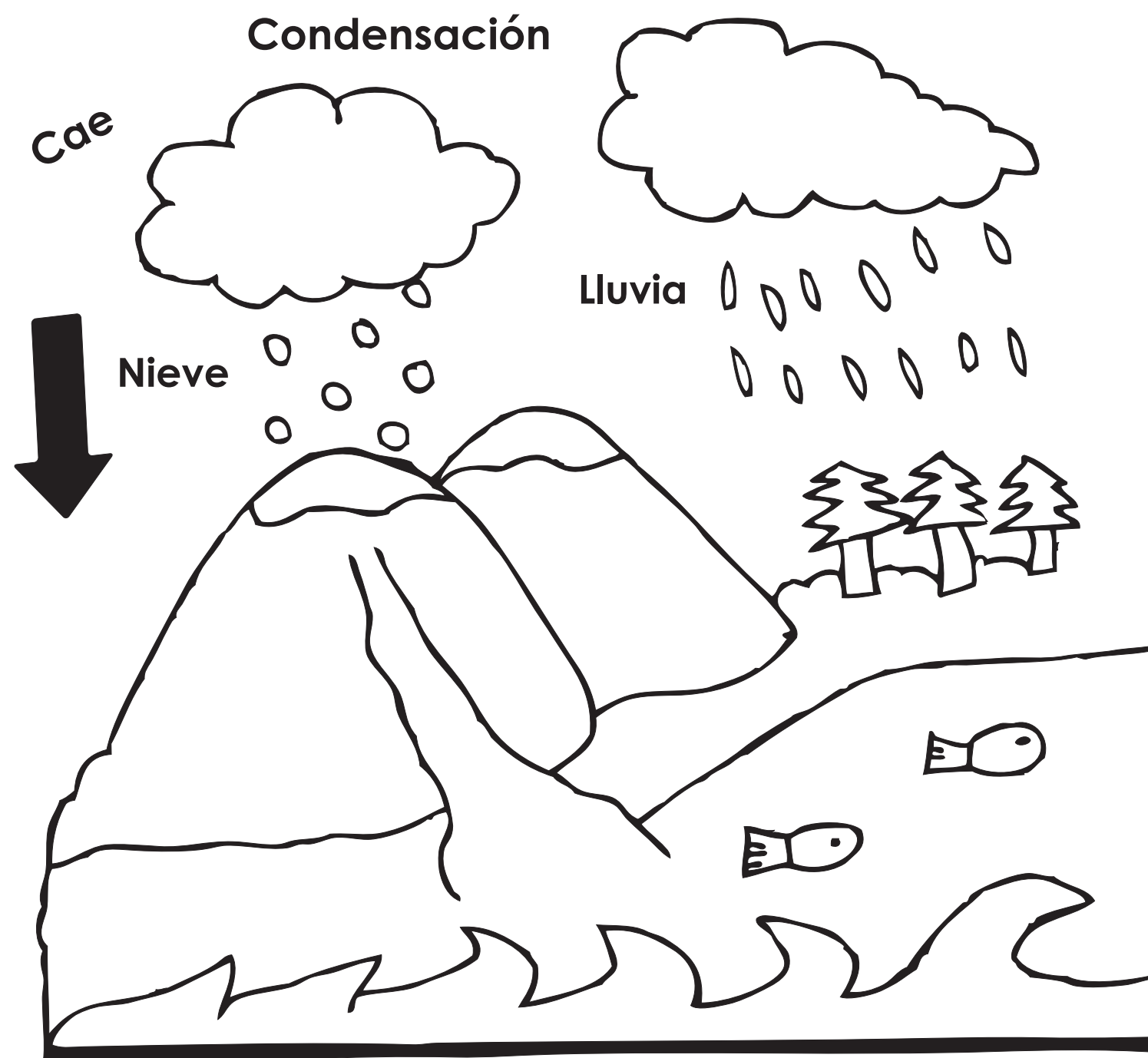




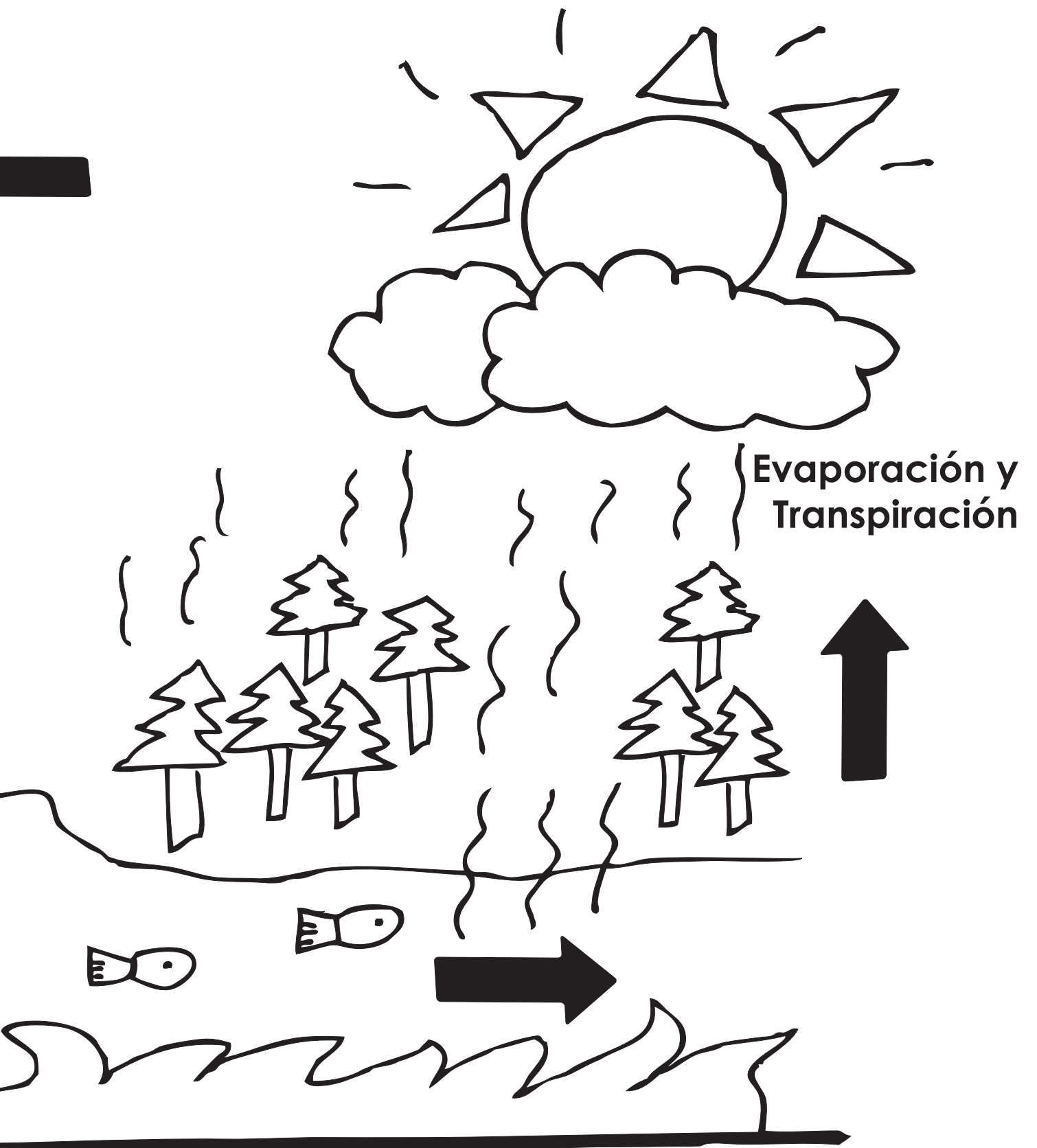

El agua va a los mares, ríos, lagos y océanos 


\section{Ciclo natural corto:}

\section{día}

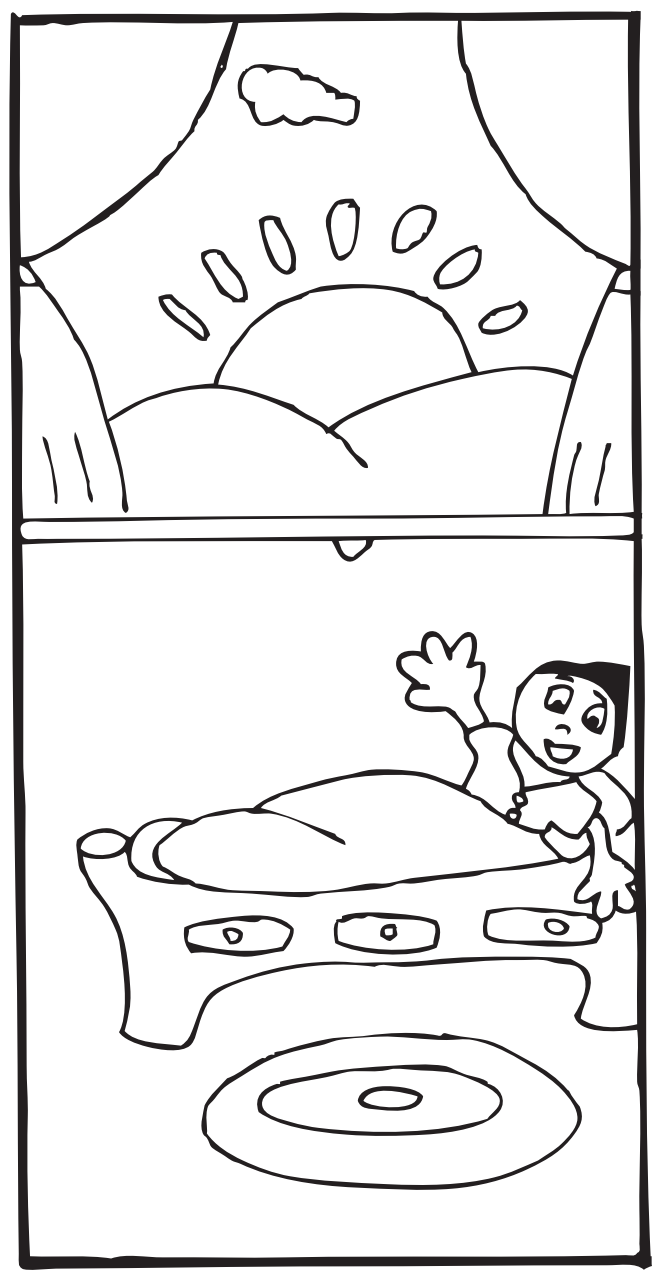




\section{noche}

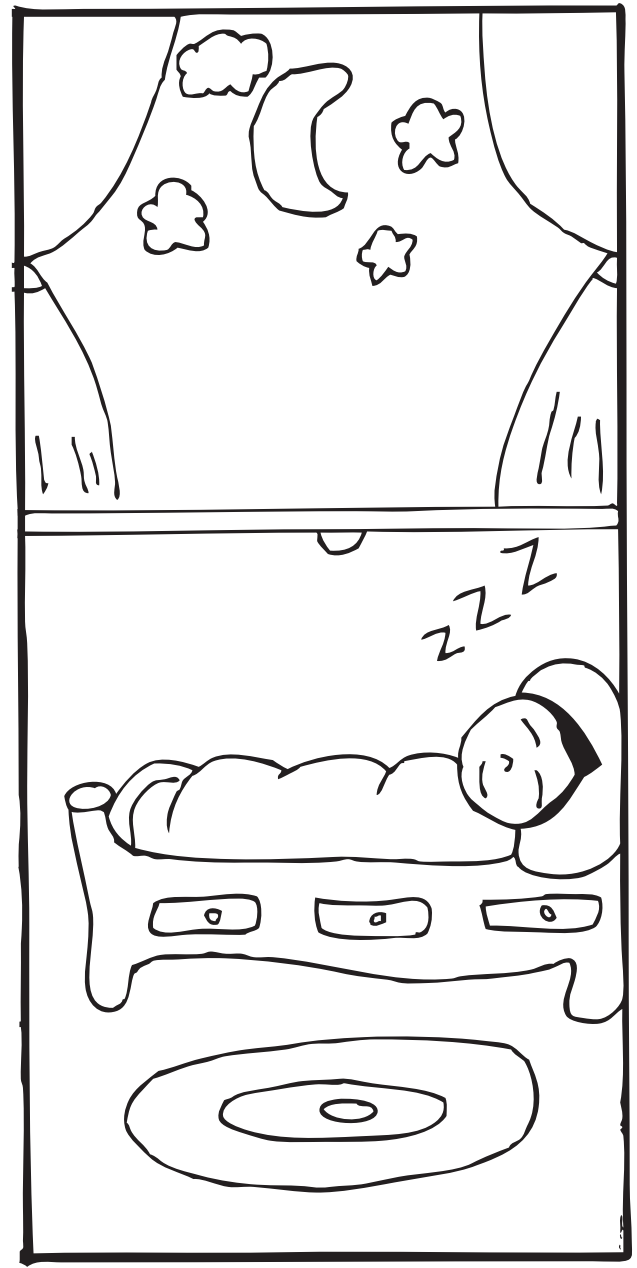




\section{Ciclo natural largo: las estaciones del año}

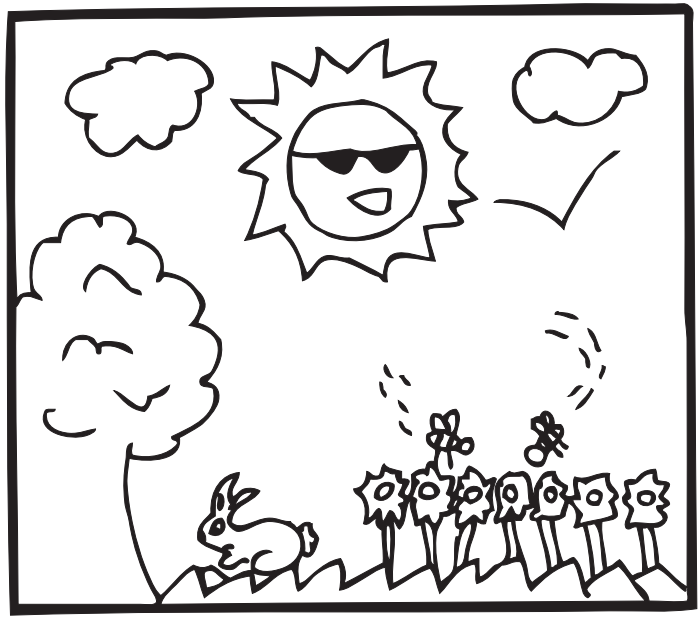

Primavera

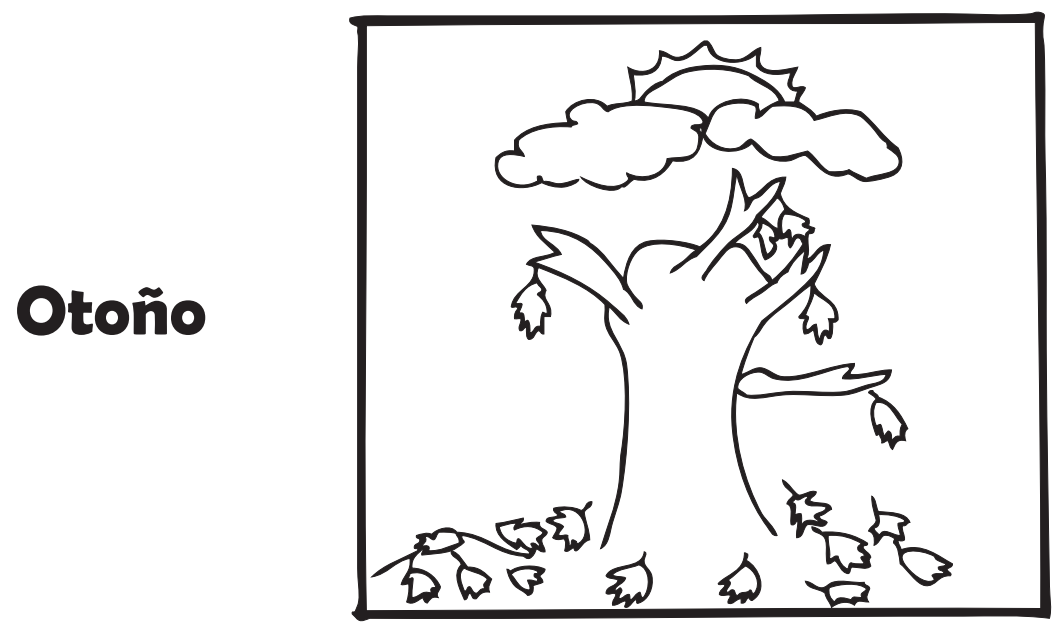




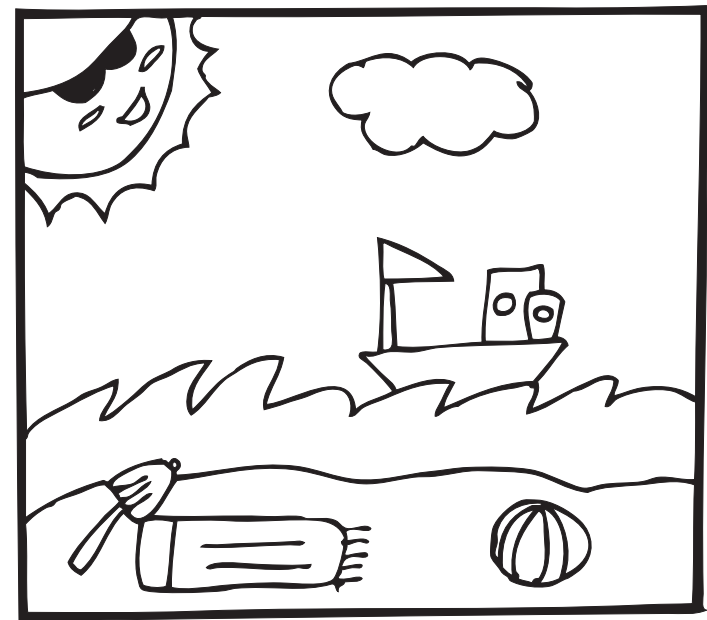

Verano

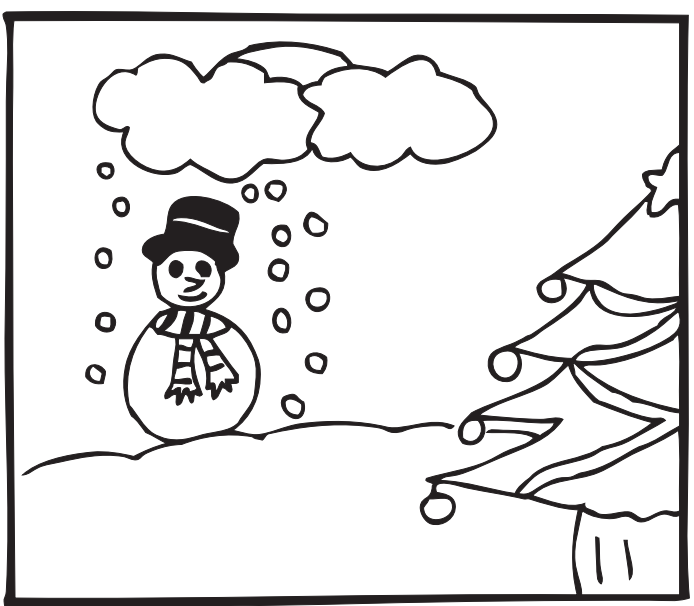




\section{Ciclo creado por el hombre:}

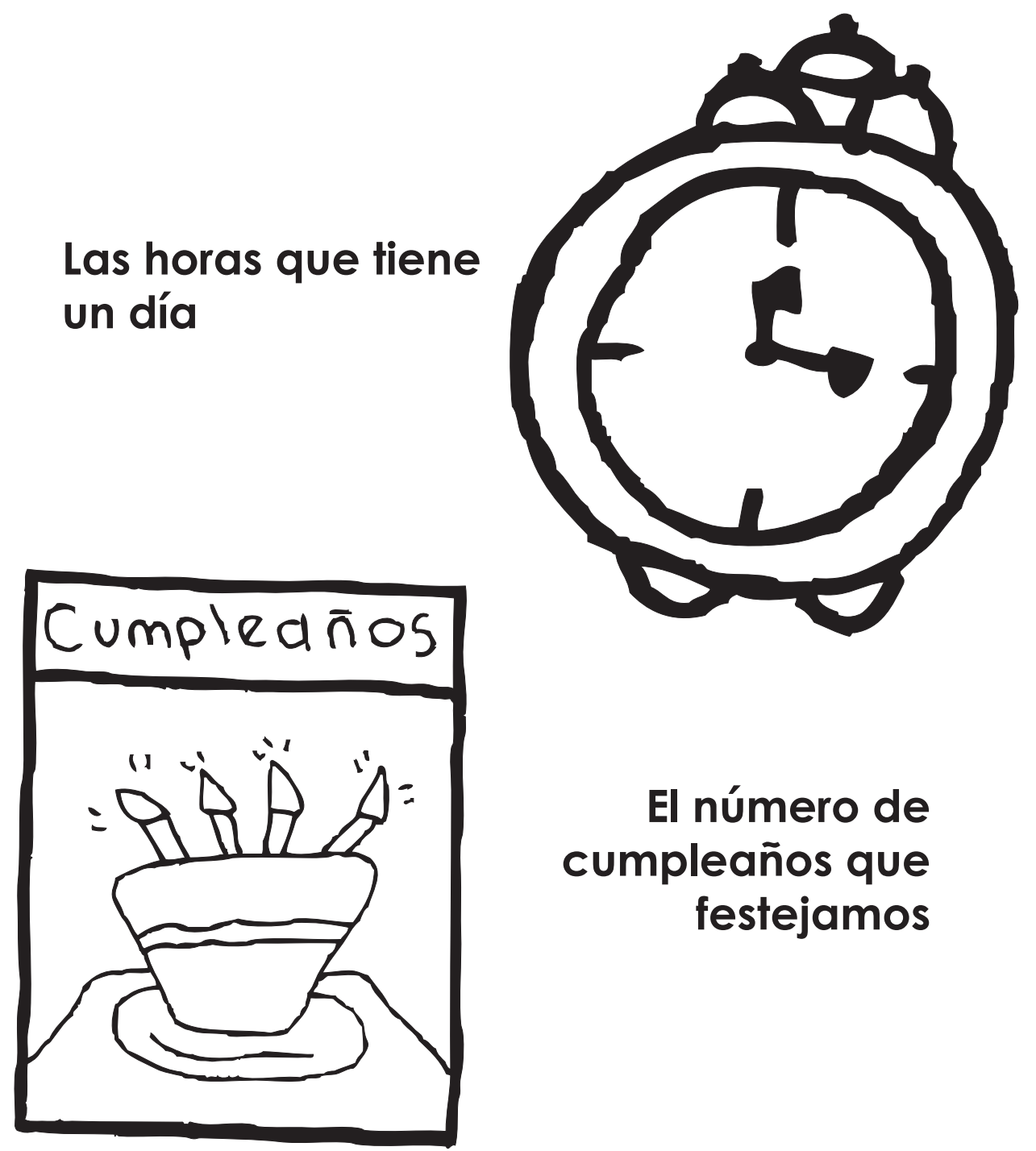




\section{Medición del tiempo}
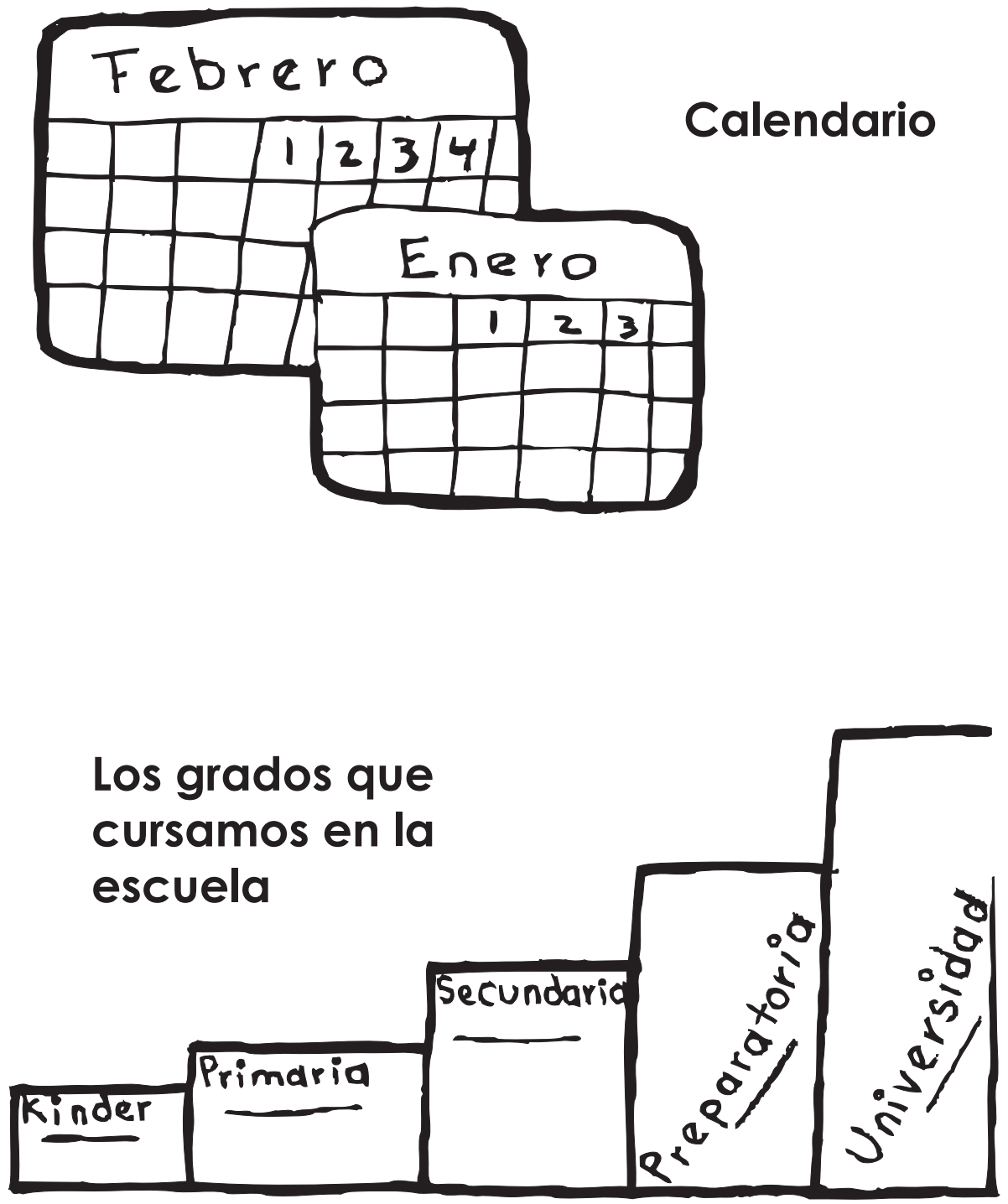


\section{Ciclo natural: ciclo de vida del ser humano}
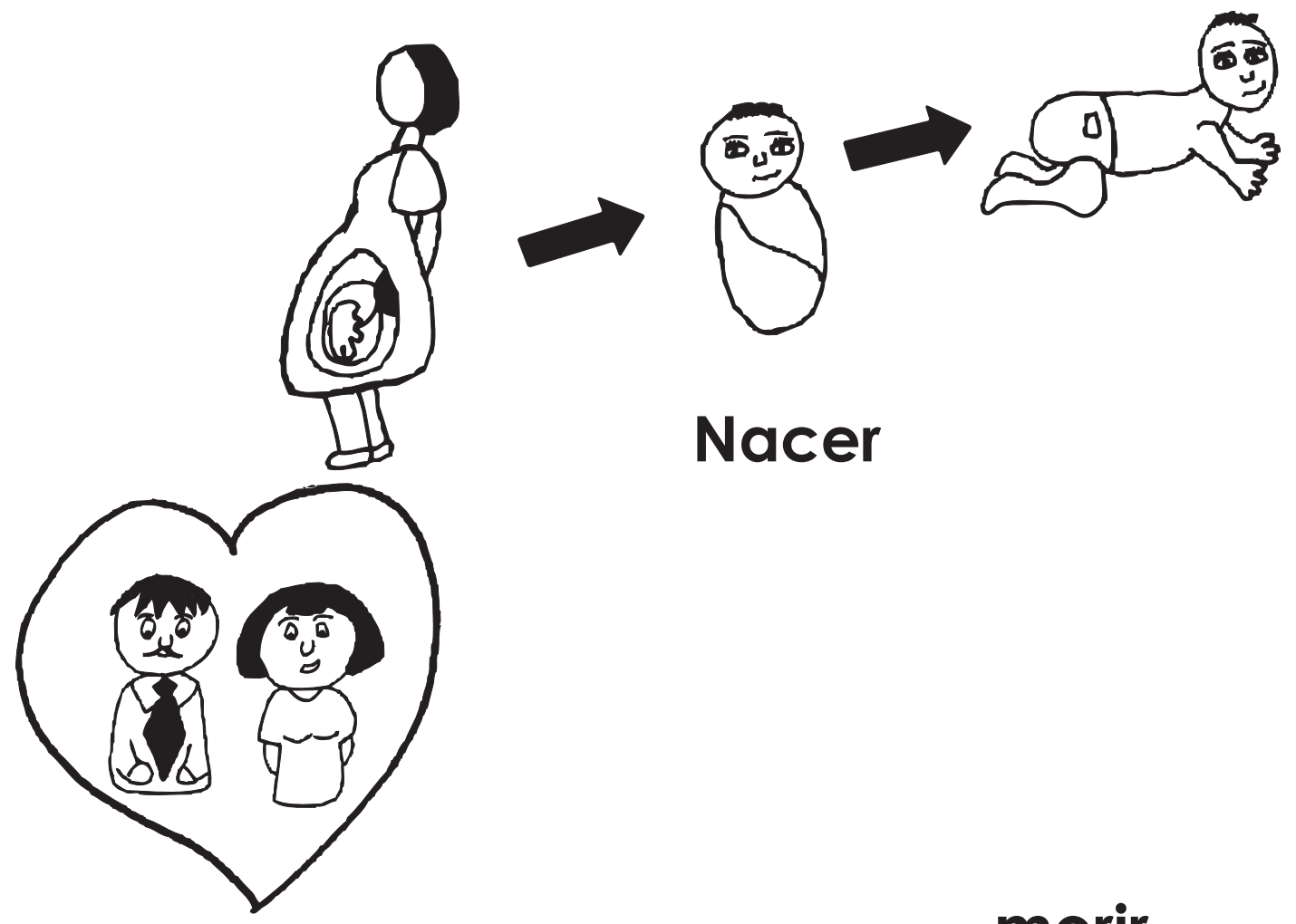

morir
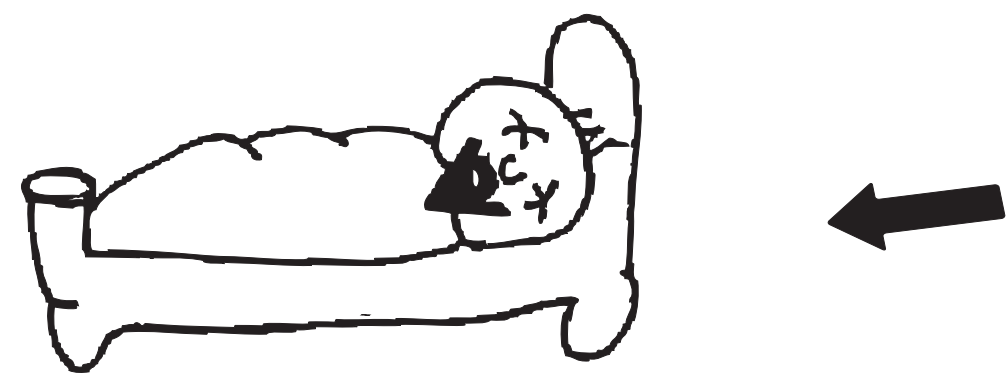

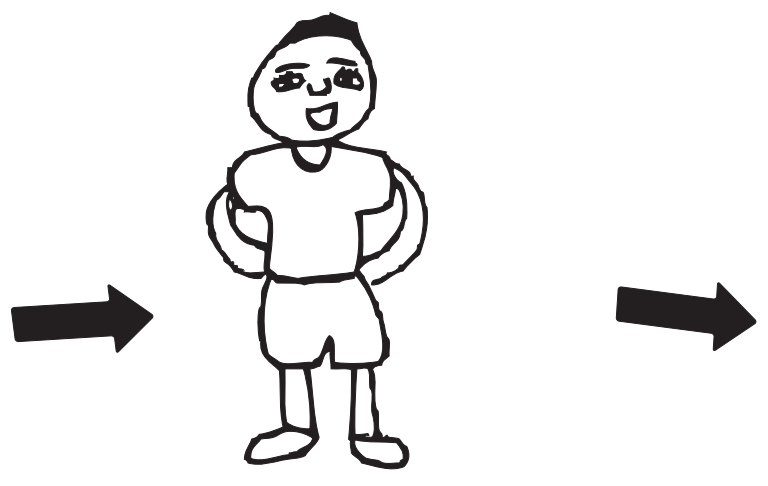

crecer

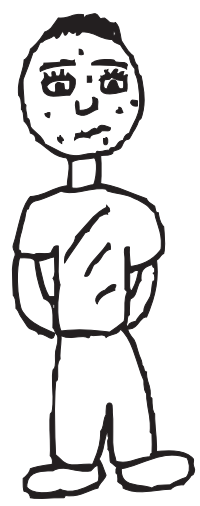

desarrollarse
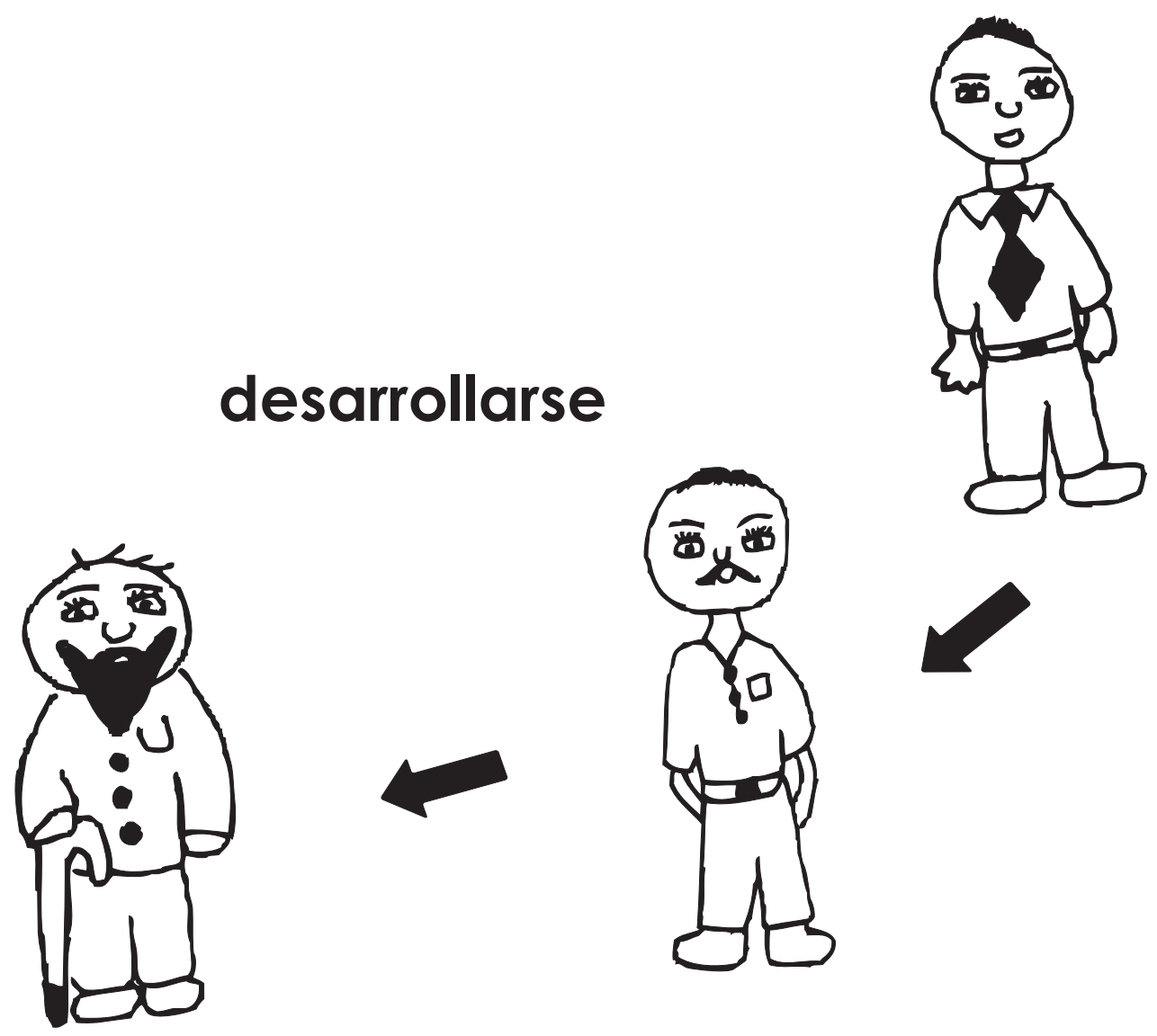

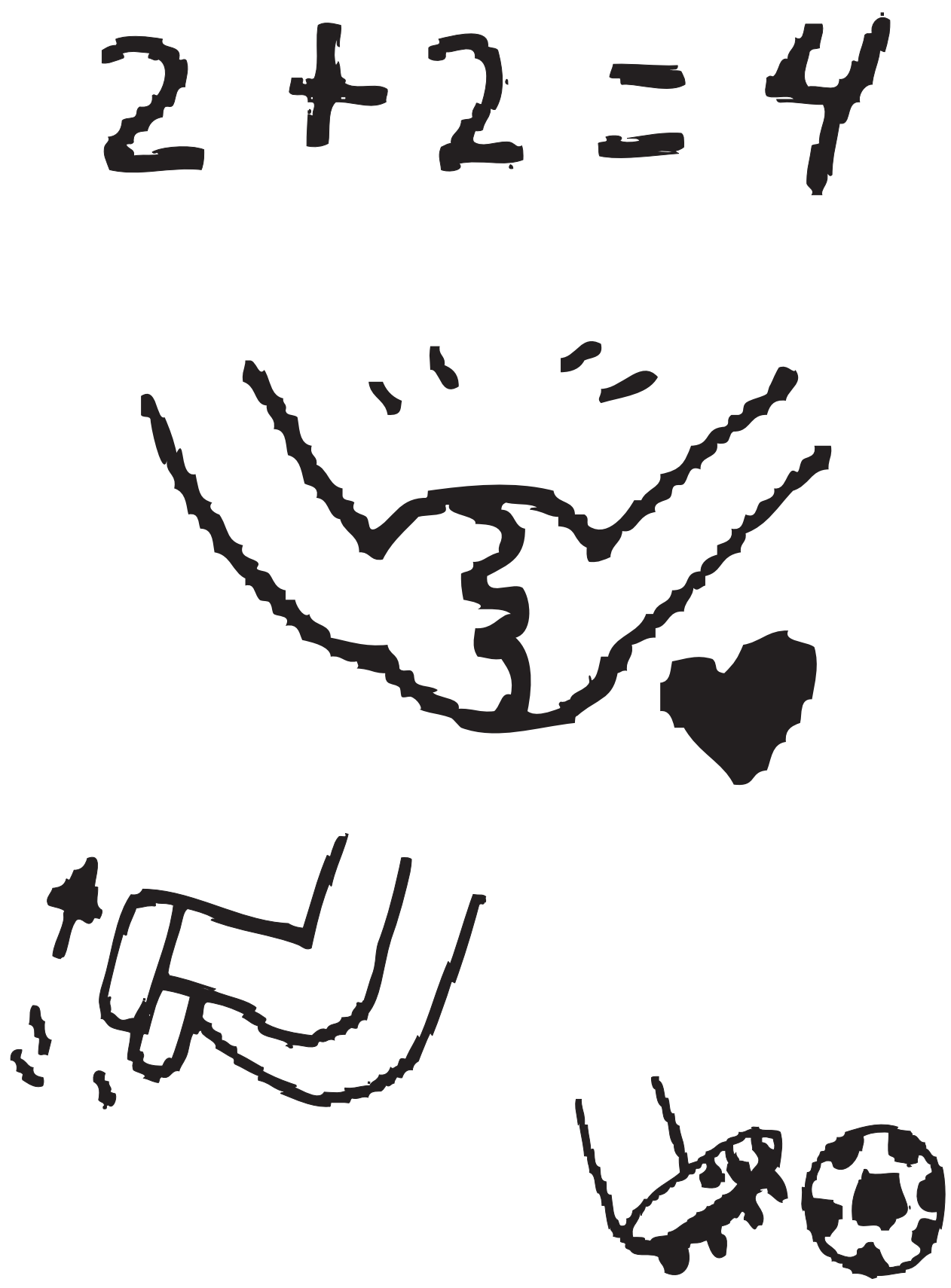


\section{Nuestras \\ capacidades como seres vivos}

Como seres vivos, los humanos tenemos un cuerpo que nos ayuda a desarrollar $e$ integrarnos en el medio que nos rodea. Este cuerpo es físico y está representado por nuestras manos, pies, cabeza y todo lo que podemos tocar. Y también tenemos un cuerpo no físico que se constituye por la personalidad y nuestra mente, que son la esencia que nos caracteriza y diferencia de otras personas.

Gracias a las habilidades que desarrollamos con nuestro cuerpo y nuestra mente, es como nos podemos relacionar, formando grupos como la familia, los amigos y la sociedad. 


\section{¿De qué están hechas las personas?}

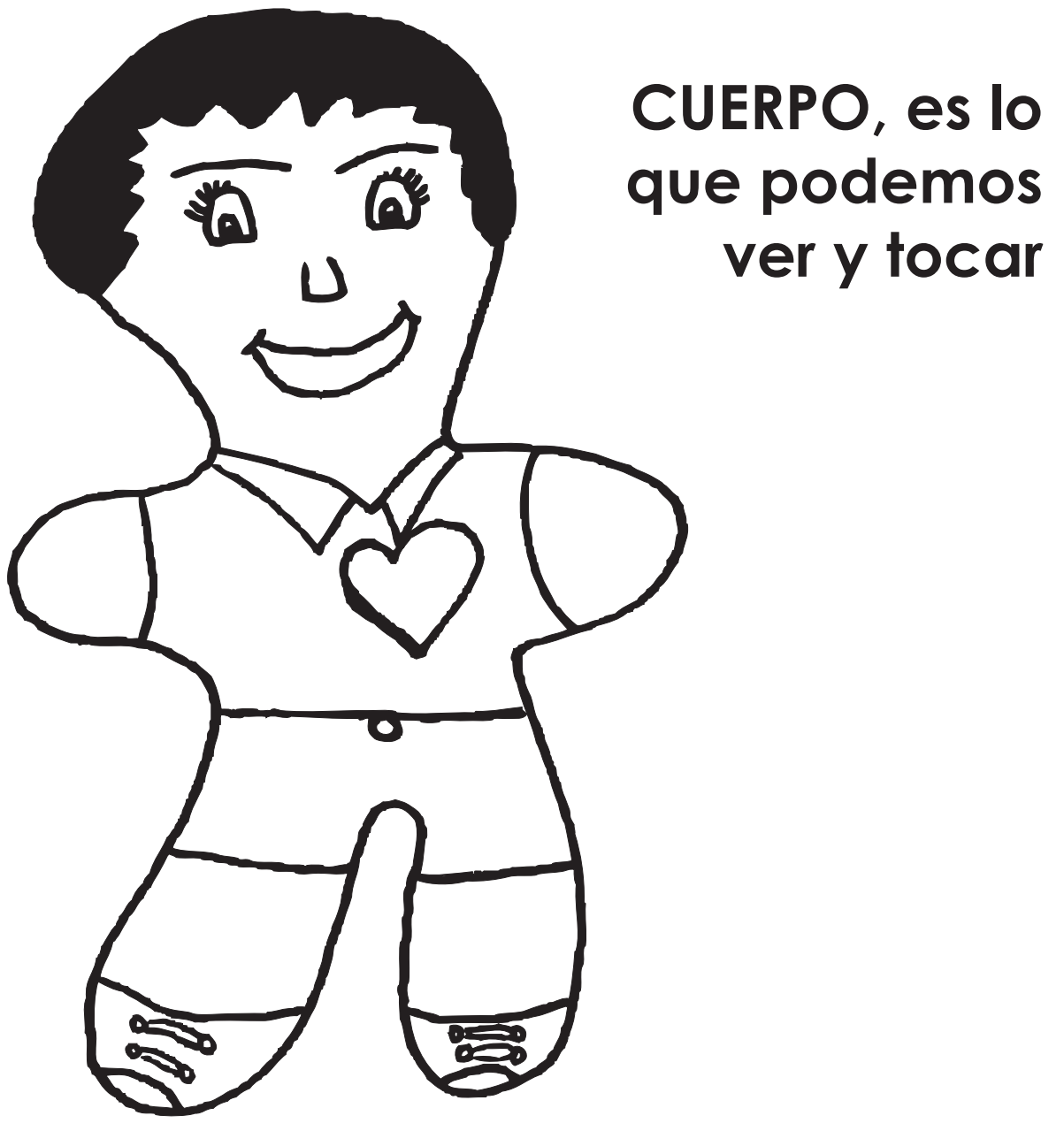




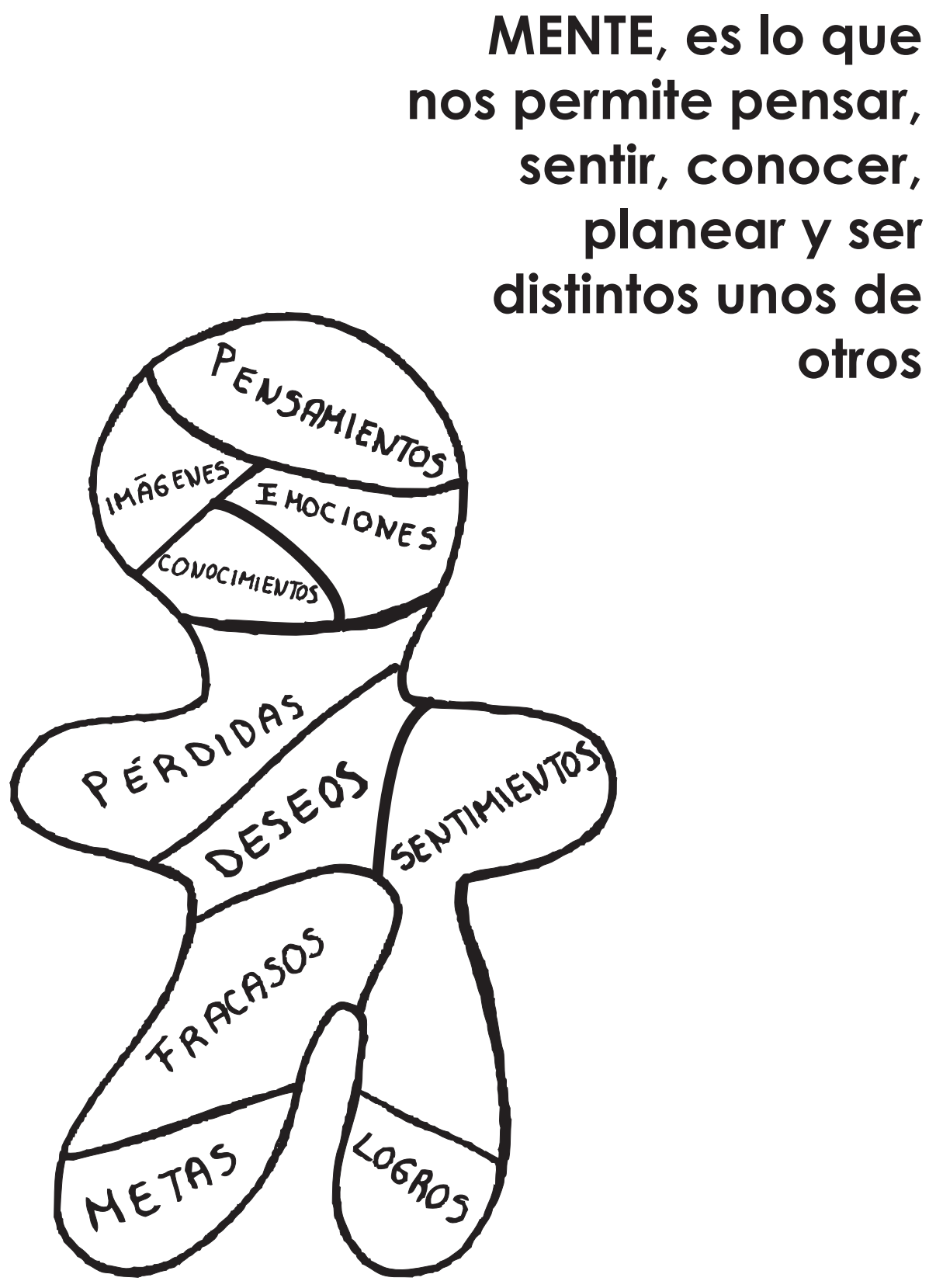




\section{Los seres humanos:}

Sentimos

Planeamos

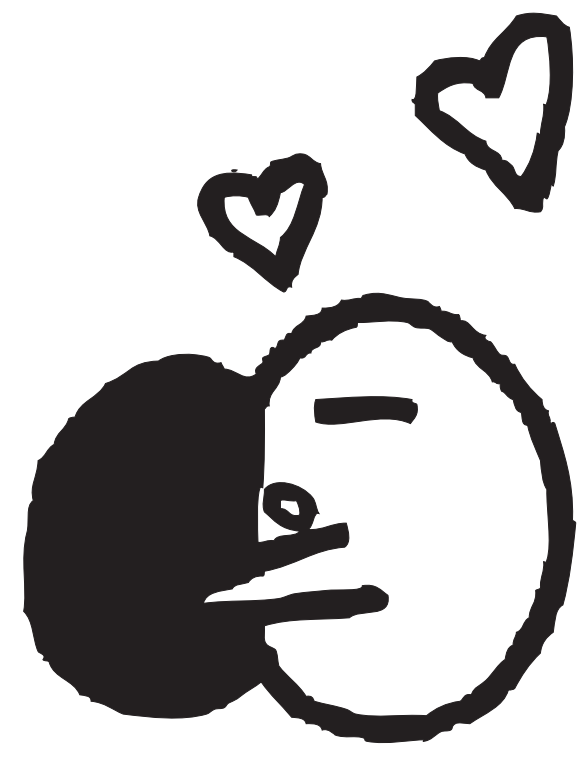

Pensamos
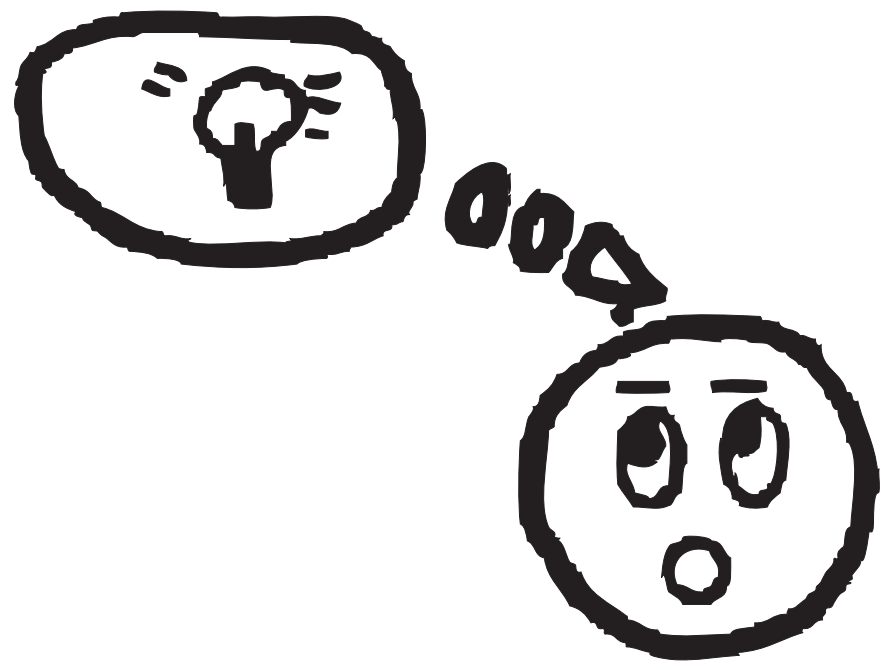


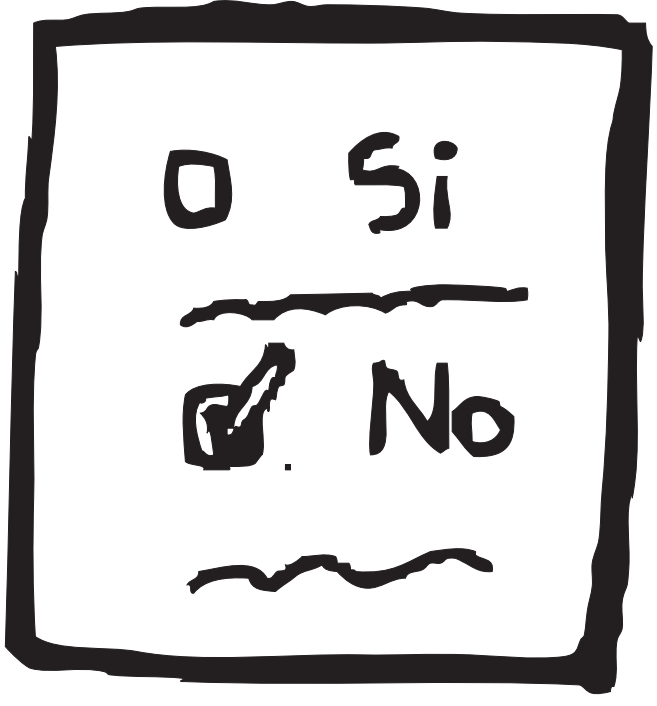

Decidimos

\section{Actuamos}

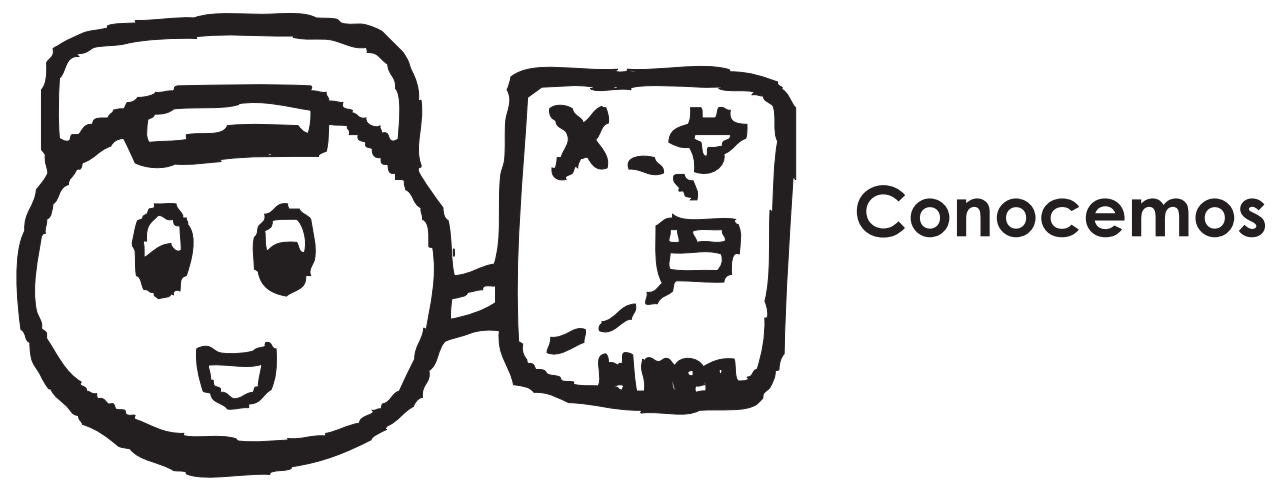


En las páginas anteriores explicamos algunas características de los seres vivos. Apóyate en ellas para escribir y dibujar algunas de tus experiencias con personas, animales 0 plantas.

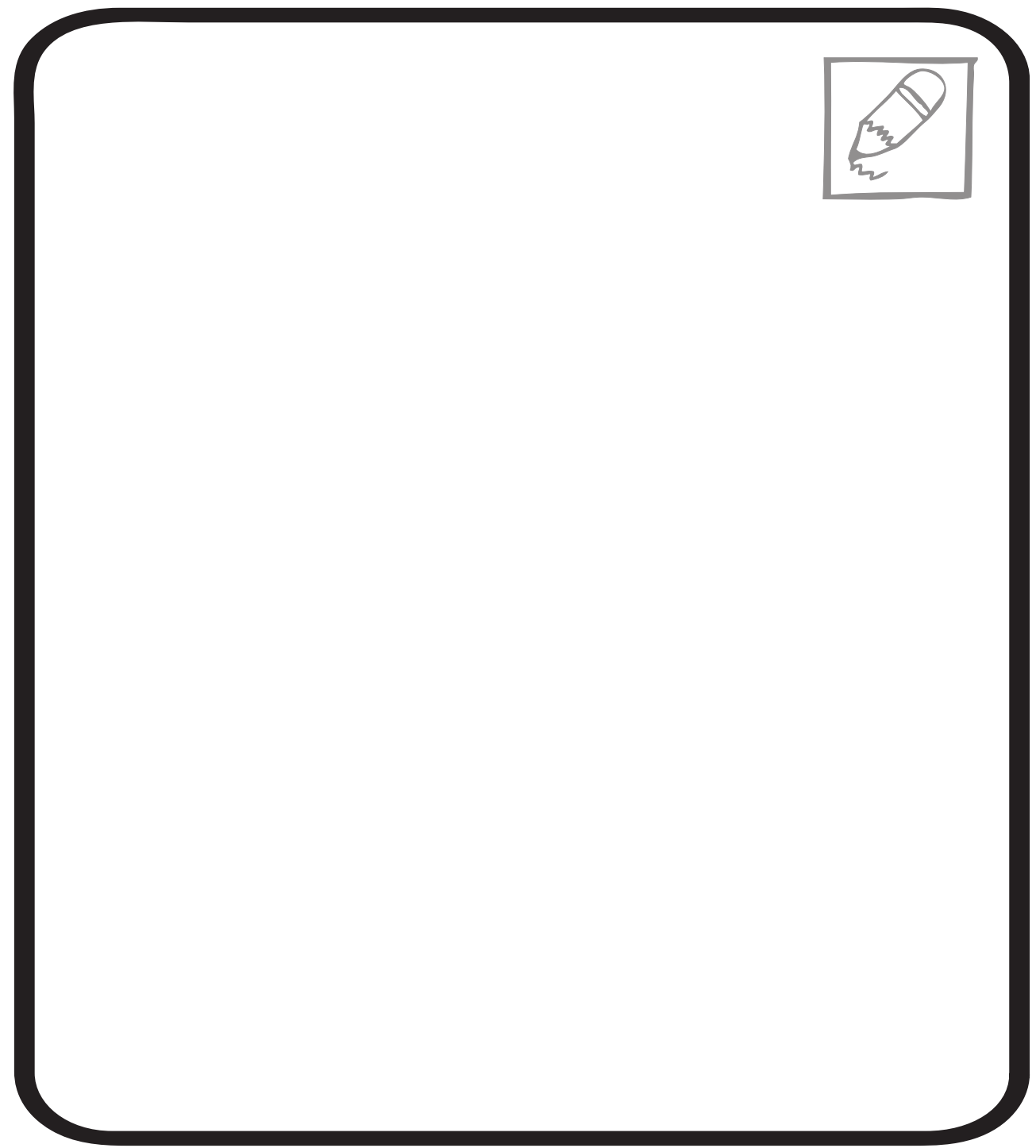




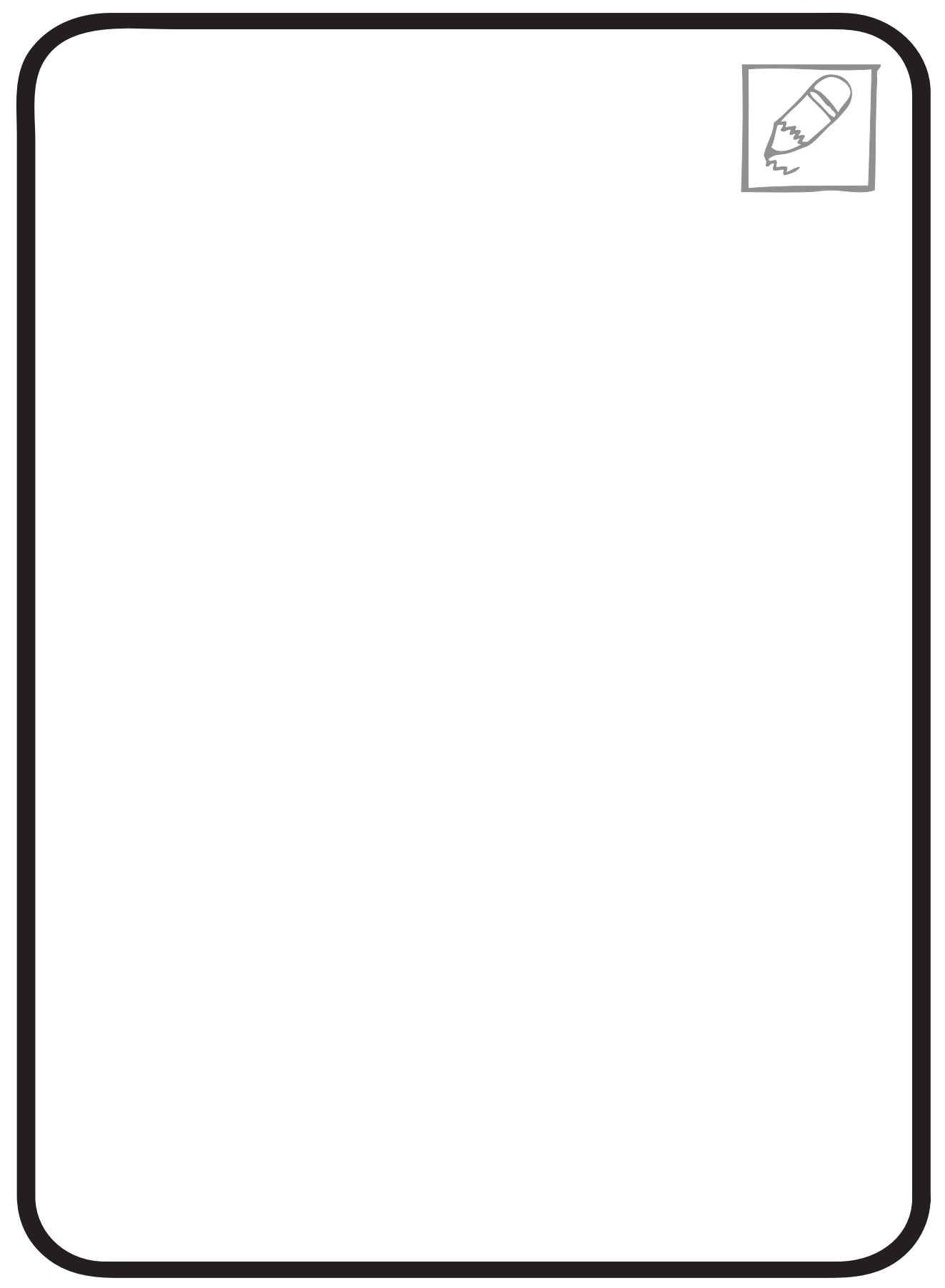


A lo largo de la vida los seres humanos somos capaces de almacenar mucha información en algunas partes de nuestro cuerpo como el cerebro, corazón, las manos y pies; esto sucede cuando reconocemos y recordamos la forma, textura y temperatura de objetos o personas. También podemos expresar emociones, escribir cartas 0 dibujar.

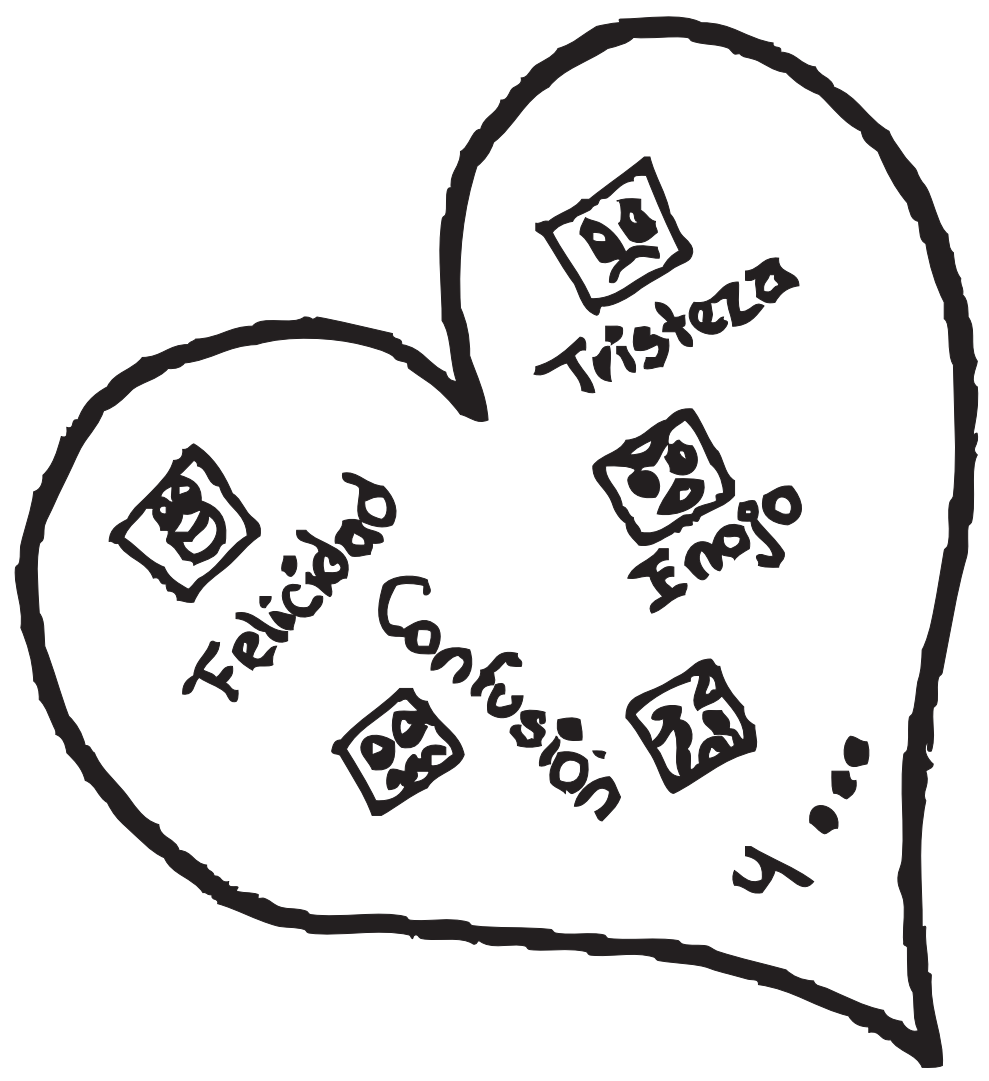




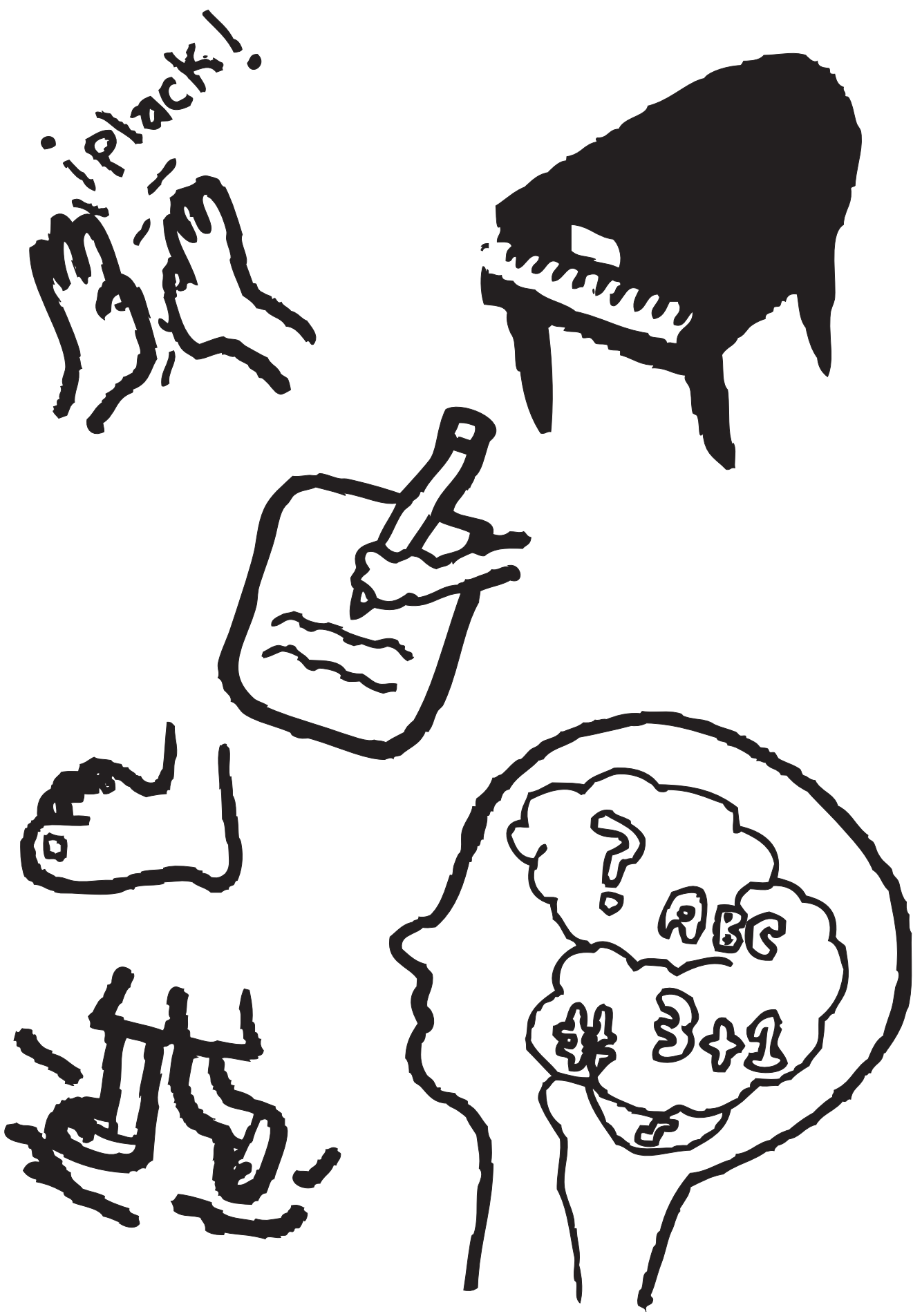


Busca en periódicos, revistas y fotos de tu familia rostros de personas felices y tristes, recórtalos y pégalos en los cuadros.

Feliz
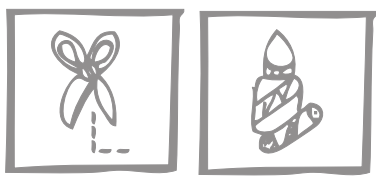
Triste

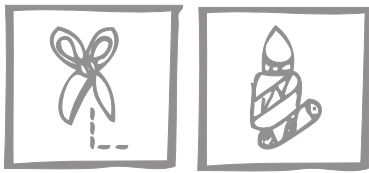


Una cualidad del ser humano es hacer planes, esto quiere decir, que puede pensar lo que quiere hacer en el futuro $y$ crear metas para alcanzarlas a lo largo de la vida.

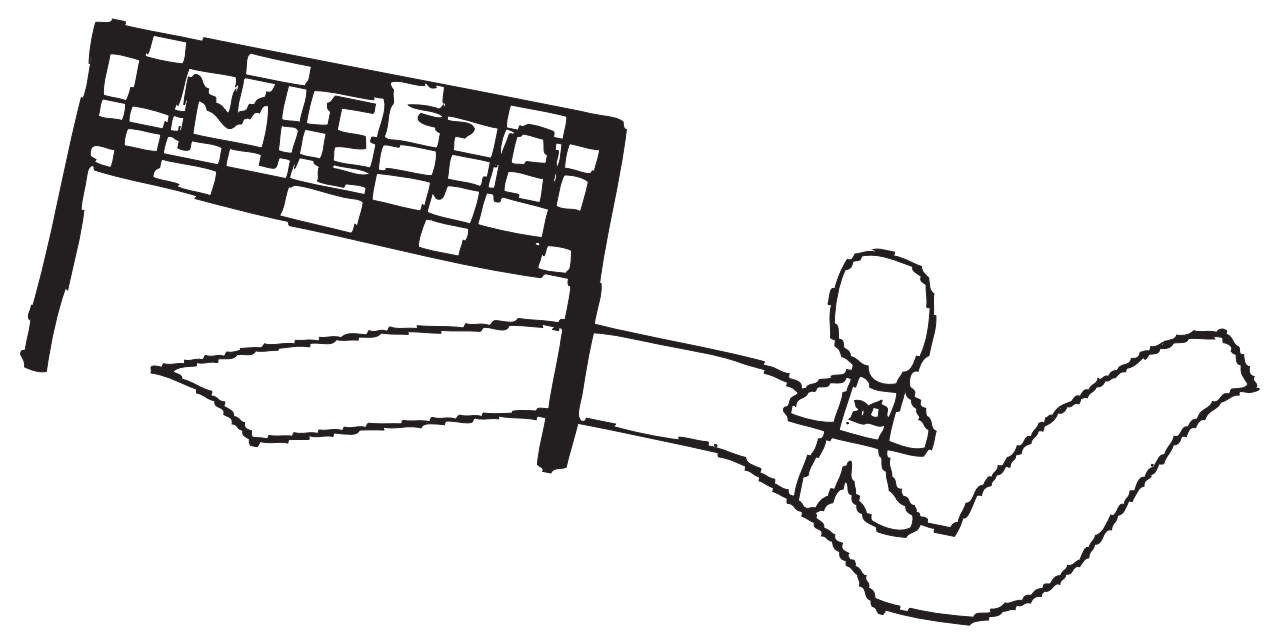




\section{¿Cuáles son tus metas?}

En 5 años

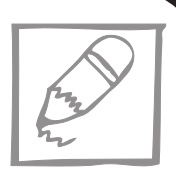

En 10 años

En 15 años

En 20 años

En 30 años

En 50 años 
Tomando en cuenta las cualidades que tenemos los seres humanos, escribe $y / 0$ dibuja la historia de tu vida desde que naciste, cuando eras más pequeño y cómo te imaginas que serás de adulto.

¡Disfruta esta actividad!

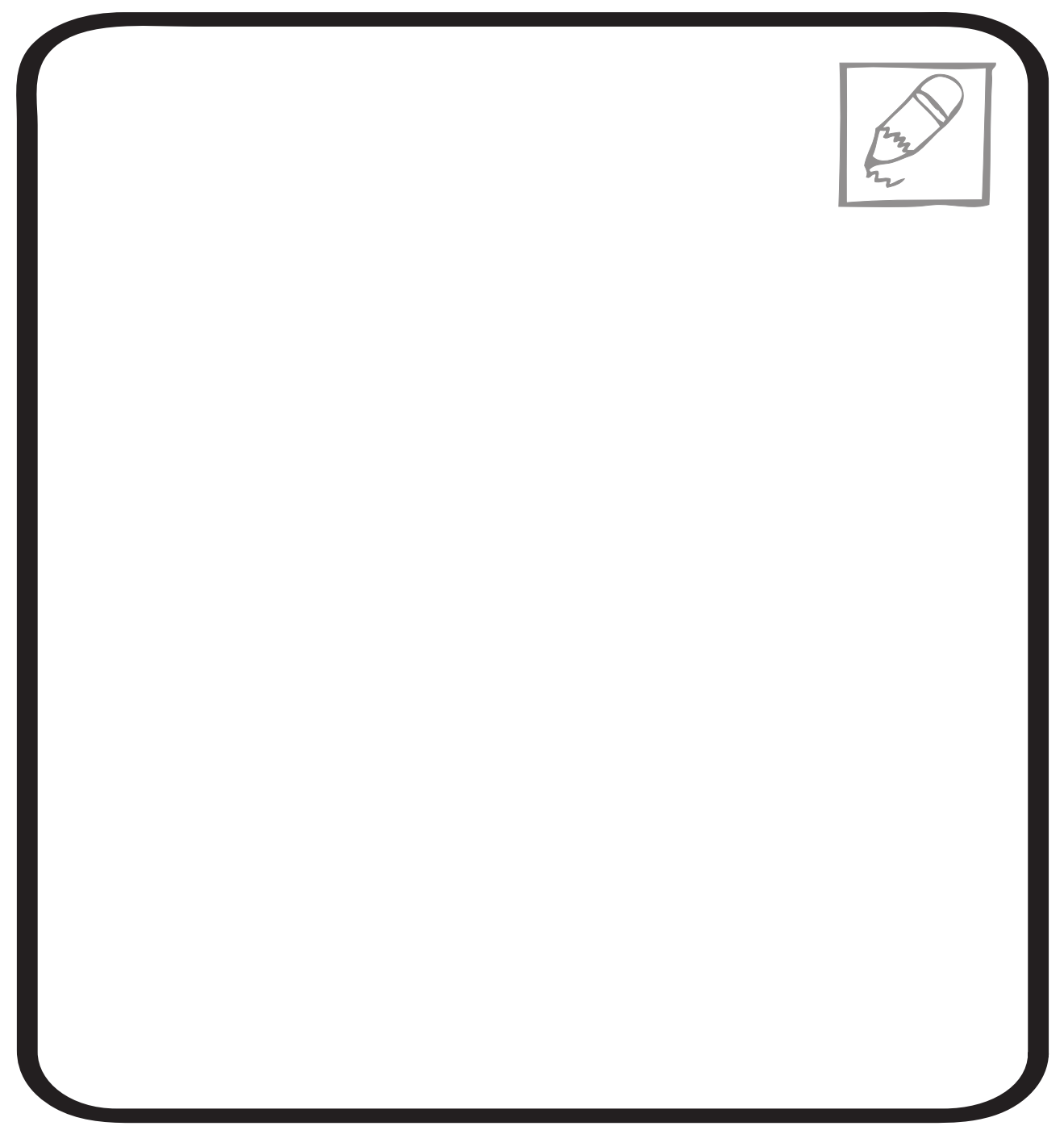




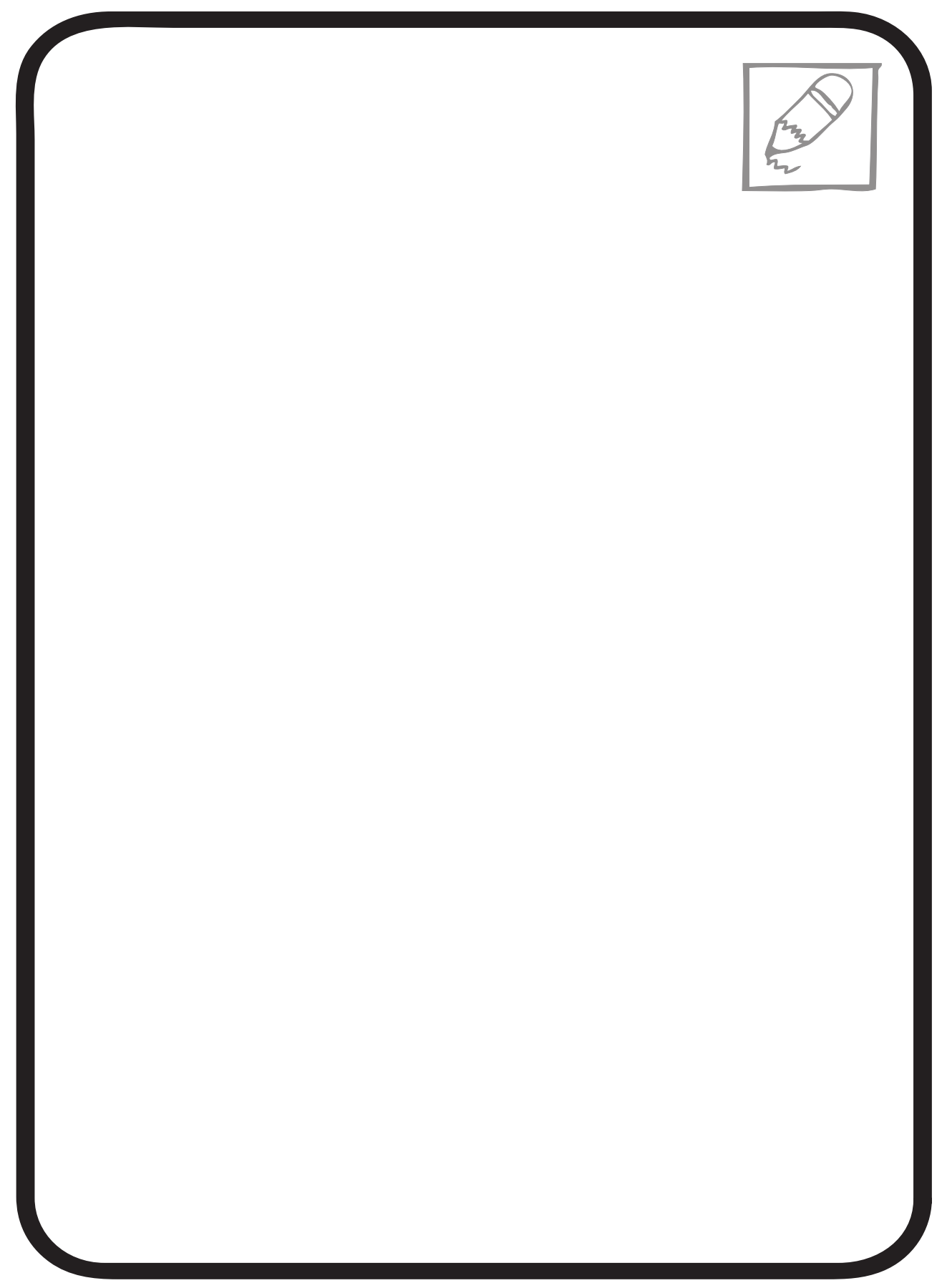




\section{iTodos formamos parte de algo!}
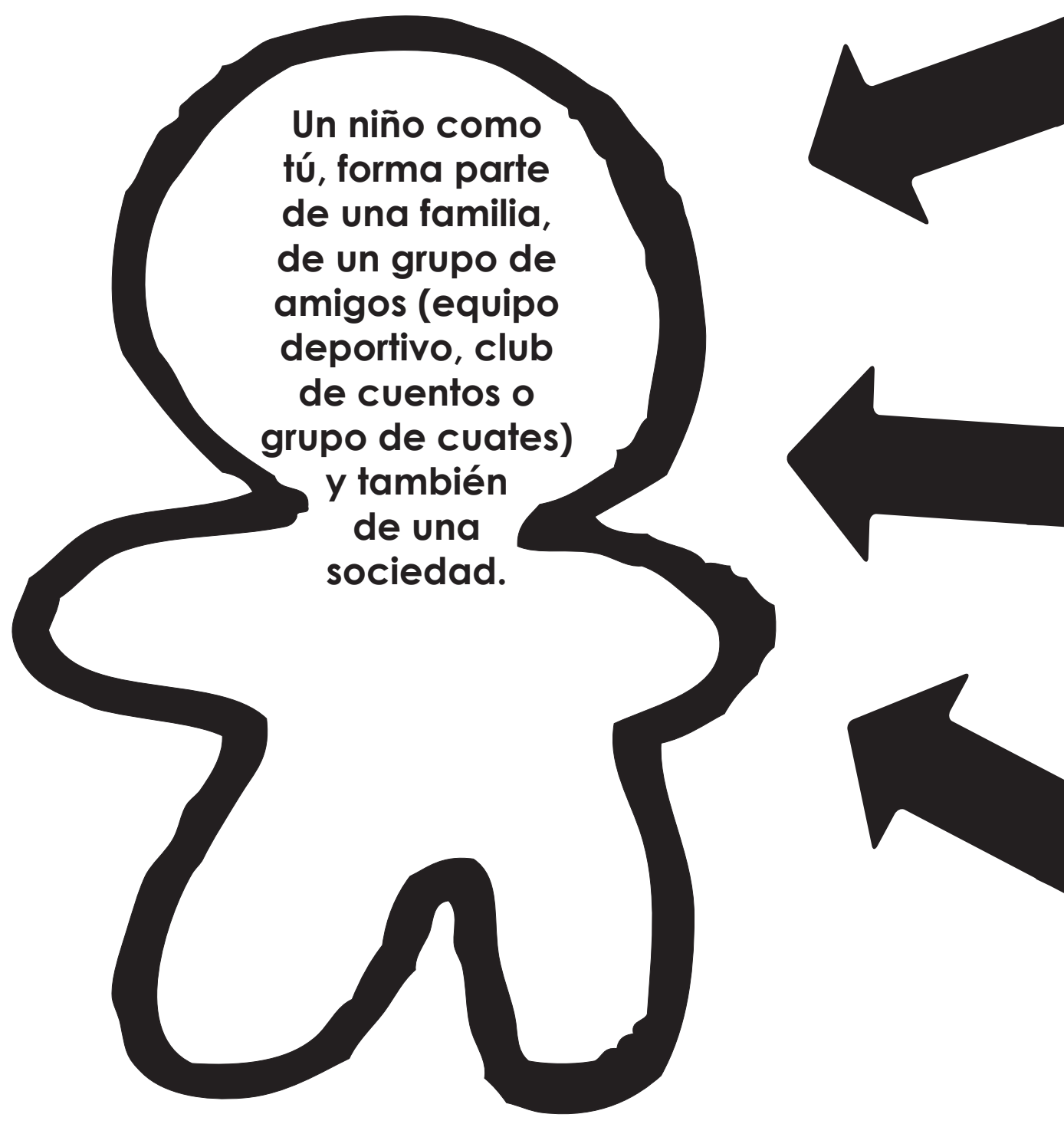


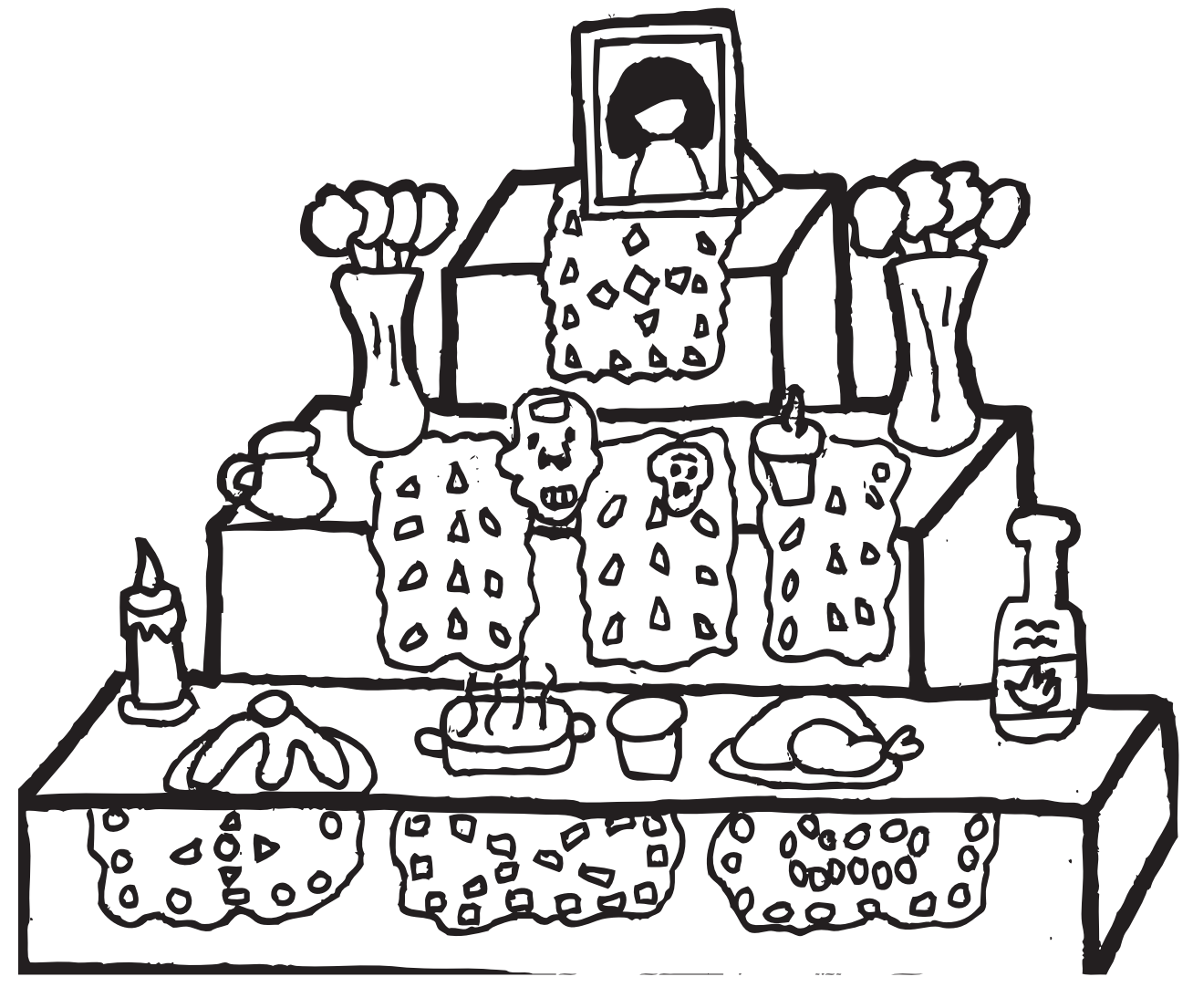




\section{La Muerte es parte de la vida}

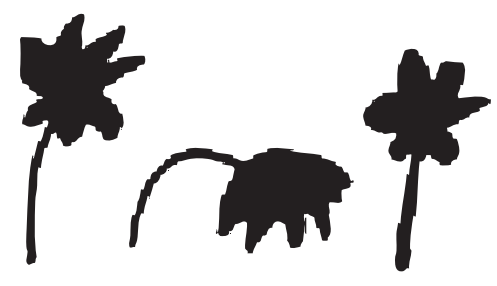

La muerte es la terminación de la vida

La muerte es el último ciclo de un ser vivo

Dependiendo de nuestras creencias, familiares y amigos nos unimos para realizar una ceremonia de despedida a la persona que murió.

A partir de que las personas mueren, las recodaremos por lo mucho que las quisimos o aprendimos de ellas.

Como parte de las tradiciones que hay en México, el $1^{\circ}$ y 2 de Noviembre se hacen ofrendas a las personas que ya murieron, para recordarlas con afecto. 
Sabemos que ha muerto una persona muy cercana a tu vida. Dibuja y escribe lo que llega a tu mente cuando piensas en él o ella.

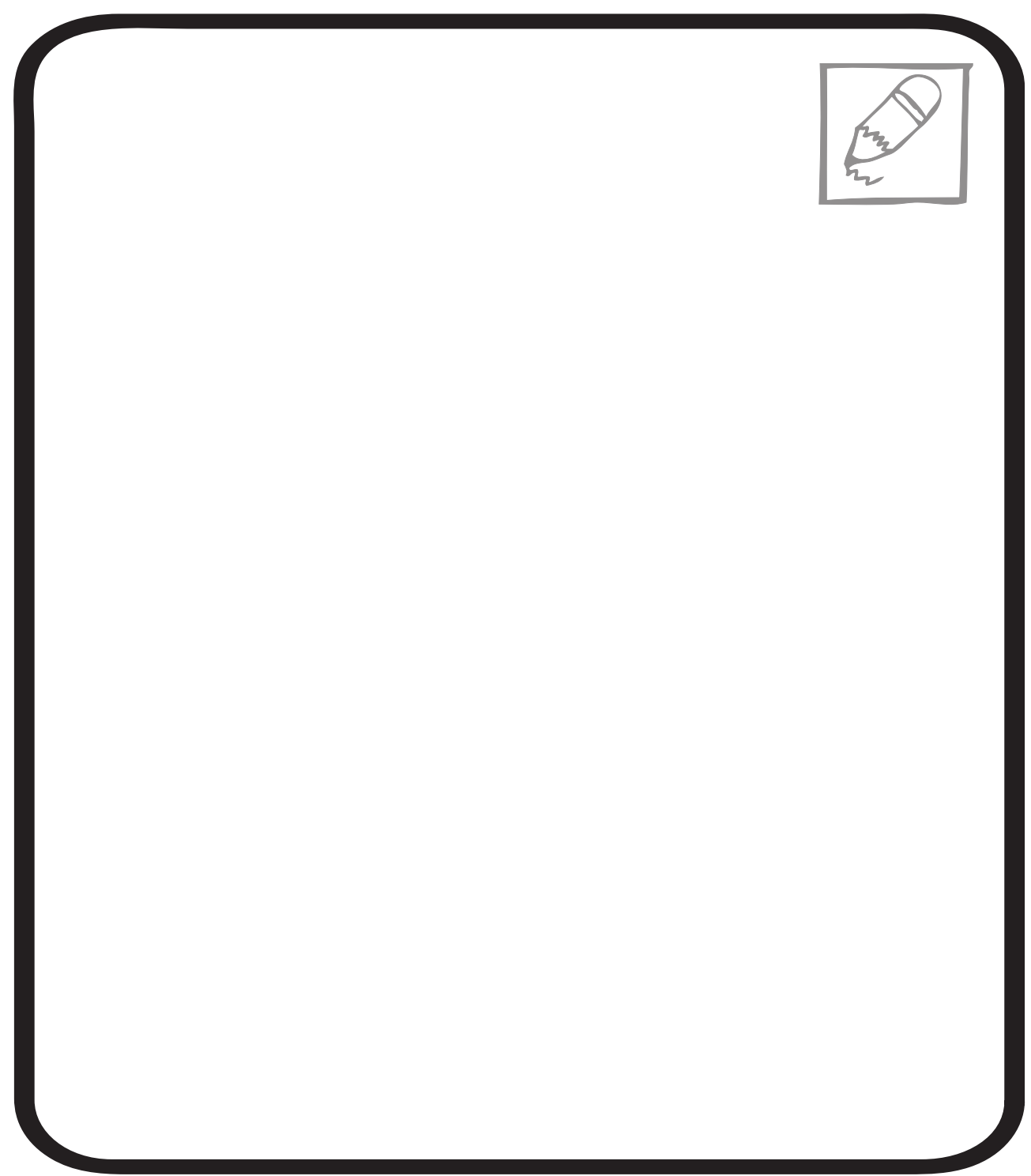




\section{Nombre de la persona}

Murió a causa de.

Te gustaría decir algo al respecto: 


\section{Tu árbol genealógico}

Instrucciones: coloca en cada una de las frutas los nombres de las personas que integran tu familia

- Los hombres en las peras

- Las mujeres en las manzanas

- Las personas que hayan muerto en las naranjas

A continuación recórtalas y pégalas en el árbol genealógico 
I

I

I
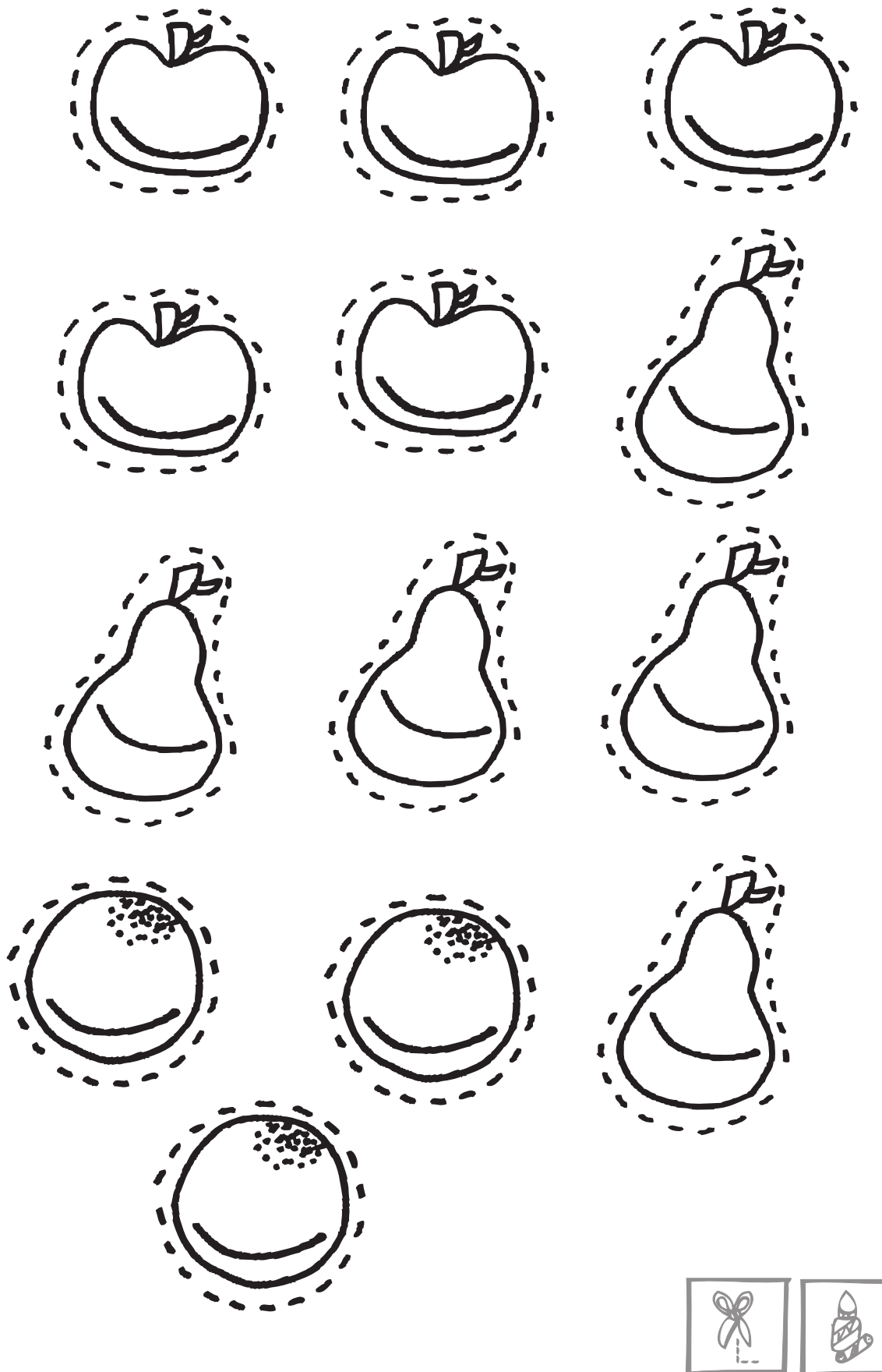


\begin{tabular}{|c|c|c|c|c|c|c|c|c|c|}
\hline 89 & 8 & 89 & 8 & 8 & Q & 89 & 89 & 89 & Q \\
\hline $\mathbb{Q}$ & 68 & $d$ & 8 & $\$$ & 8 & $d$ & 8 & $\mathscr{O}$ & 8 \\
\hline 8 & 8 & 8 & $g$ & 8 & 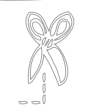 & 8 & 8 & 8 & g \\
\hline $\mathscr{d}$ & bs & $\mathscr{E}$ & 8 & 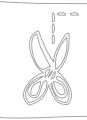 & 8 & $d$ & bs & $\mathscr{E}$ & 8 \\
\hline 89 & 8 & 8 & 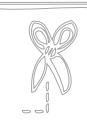 & 8 & Q & 8 & 89 & 89 & $g$ \\
\hline$d$ & 8 & of & bs & $\mathscr{d}$ & \&s & $\&$ & is & $\mathscr{b}$ & 8 \\
\hline 8 & 8 & 8 & $g$ & 8 & 8 & 8 & 89 & 89 & $g$ \\
\hline 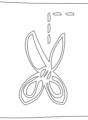 & 8 & $\mathscr{b}$ & 8 & 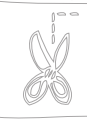 & 8 & $\mathscr{d}$ & is & $\mathscr{b}$ & 8 \\
\hline 89 & 8 & 8 & gQ & 88 & Q & 89 & 89 & 89 & 8 \\
\hline $\mathscr{D}$ & is & $\mathscr{d}$ & is & $d$ & is & $d$ & If & $\mathscr{E}$ & \& \\
\hline 89 & 8 & 8 & $g 8$ & 8 & 8 & 89 & 89 & 89 & Q \\
\hline $\mathscr{d}$ & 8 & $\&$ & 8 & $\mathscr{D}$ & \& & $\mathscr{L}$ & is & $\mathscr{E}$ & $b$ \\
\hline 8 & 88 & 89 & 8 & 89 & 8 & 89 & 8 & 89 & 89 \\
\hline 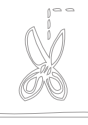 & 8 & $\&$ & 8 & 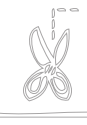 & 8 & $\mathscr{D}$ & 8 & $\mathscr{b}$ & $b$ \\
\hline
\end{tabular}




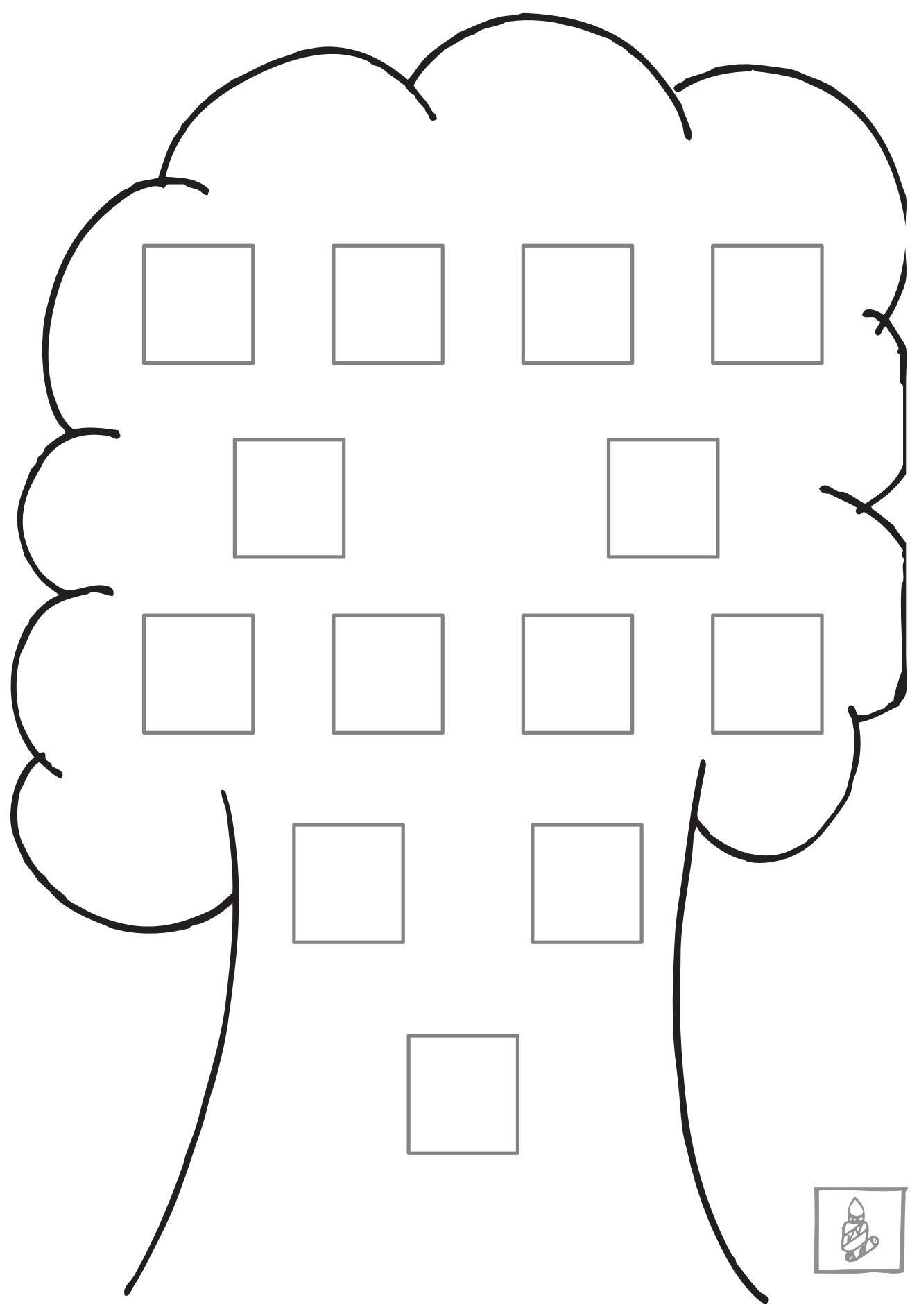




\section{Cuando alguien muere, se crea un remolino de sentimientos}

\section{ڤ̊Tú qué sientes}

\section{en ese}

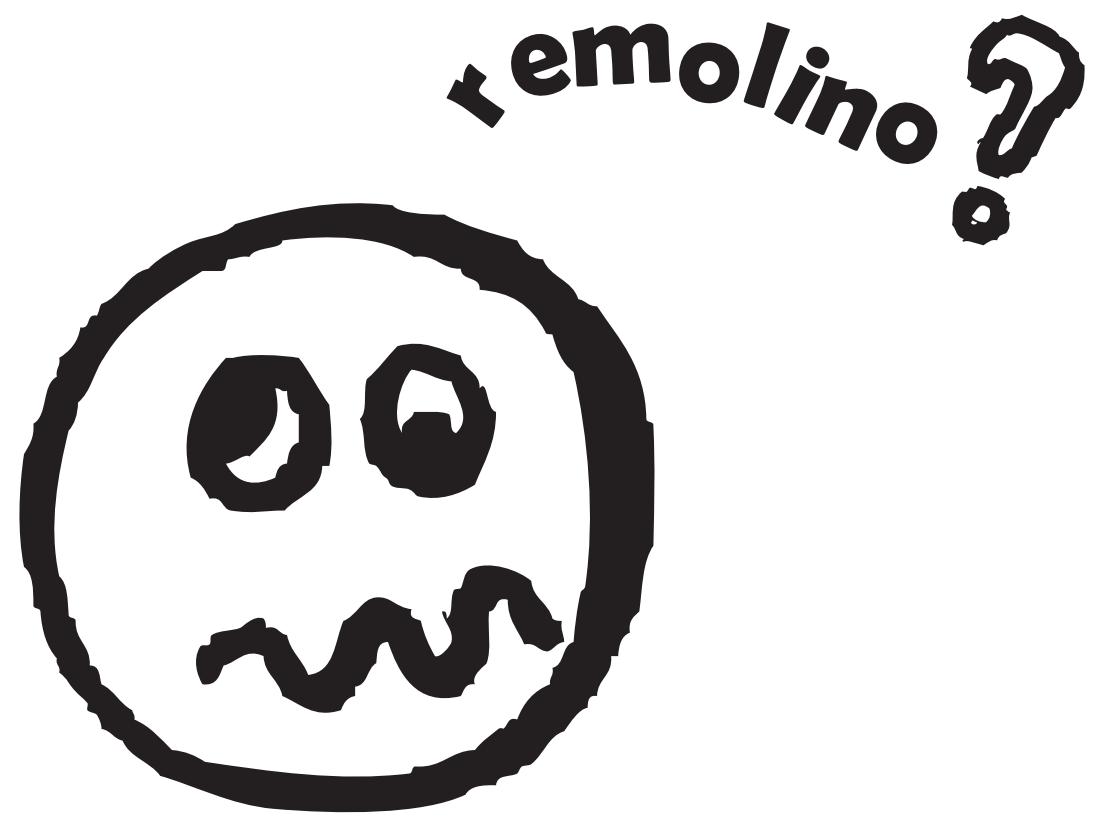


Rellena los espacios en blanco con palabras que reflejen tus sentimientos
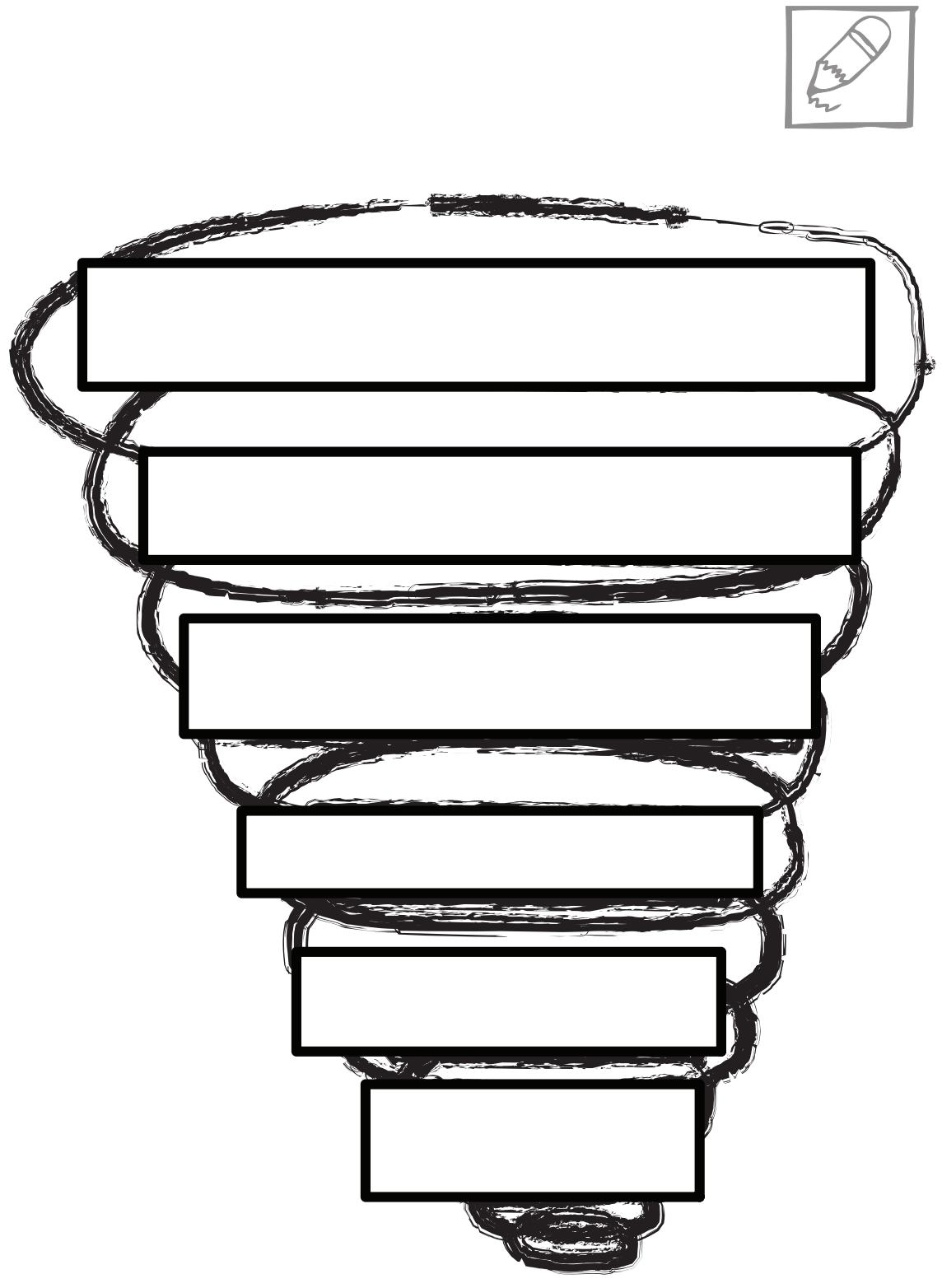
Escribe lo que nunca le hayas dicho a esa persona que murió, pero que te gustaría decirle

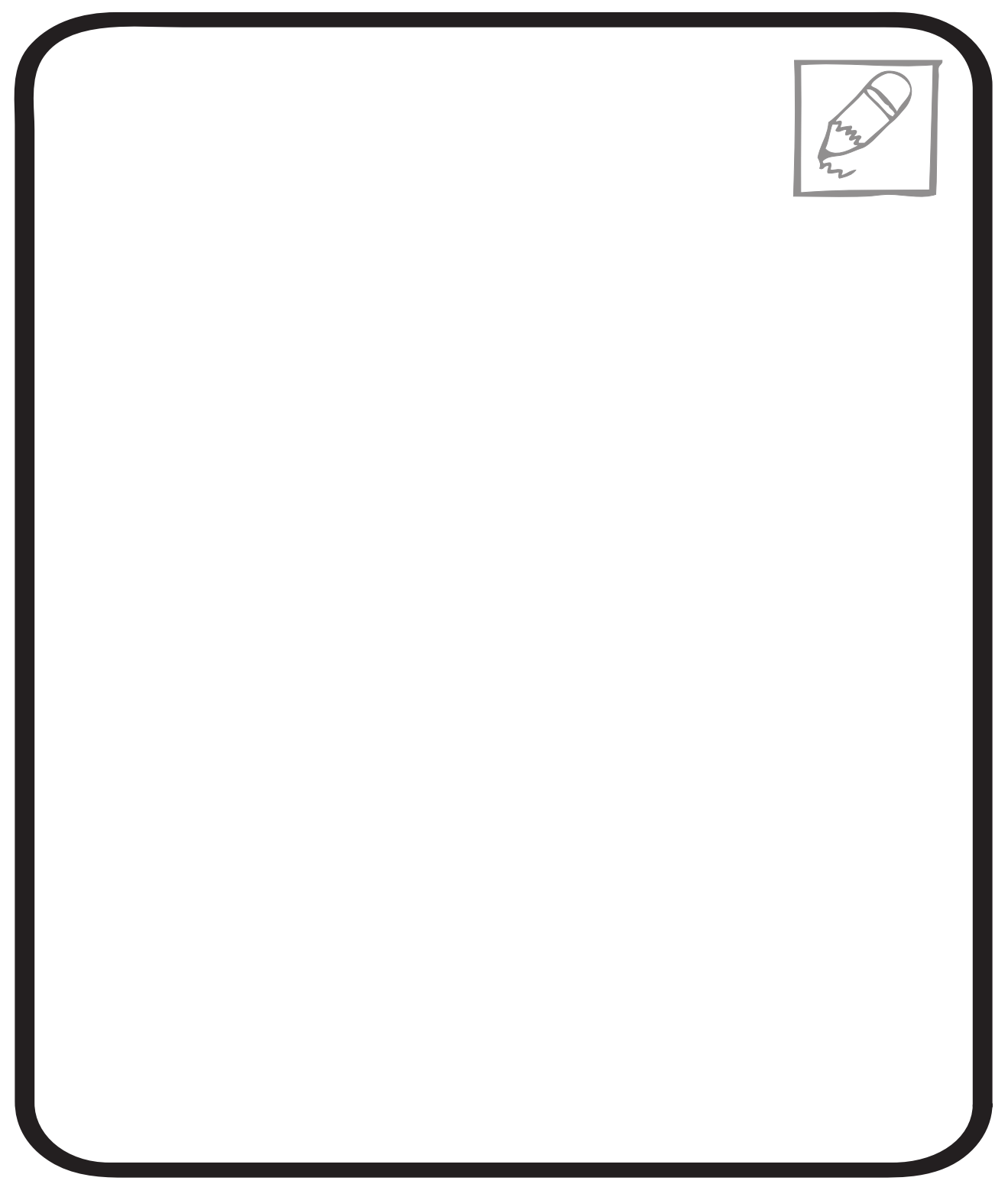


¿Te diste cuenta que después de que murió esa persona, toda tu familia se reunió?

Esto se hace para despedirse del cuerpo de la persona. Aunque esto es un proceso difícil de aceptar, se debe realizar para que la persona muerta esté preparada para dejar este mundo.

En ocasiones se hacen cantos, rezos, dependiendo de las costumbres de cada familia y eso se realiza para iniciar un nuevo ciclo en nuestra vida.

Es importante que las personas que aún estamos vivas sigamos con nuestros planes, metas y obligaciones. También es muy necesario que platiquemos sobre nuestras emociones, dudas o preguntas. 
Cuando alguien muere, su cuerpo deja de funcionar, pero pensar en esa persona es lo que nos ayuda a conservar los recuerdos $y$ el amor que nos teníamos.

Escribe los momentos más significativos que viviste con la persona que ha muerto 

A lo largo de estas páginas, hemos tratado de explicarte la vida, la muerte y lo que gira en torno a ellas, tal vez te sientes confundido o tienes alguna duda respecto a estos temas.

Esta página es para que preguntes todo lo que aún quieres saber, con esto lograrás liberarte de miedos, angustias e inquietudes que esos pensamientos te generan.

Mis preguntas son:

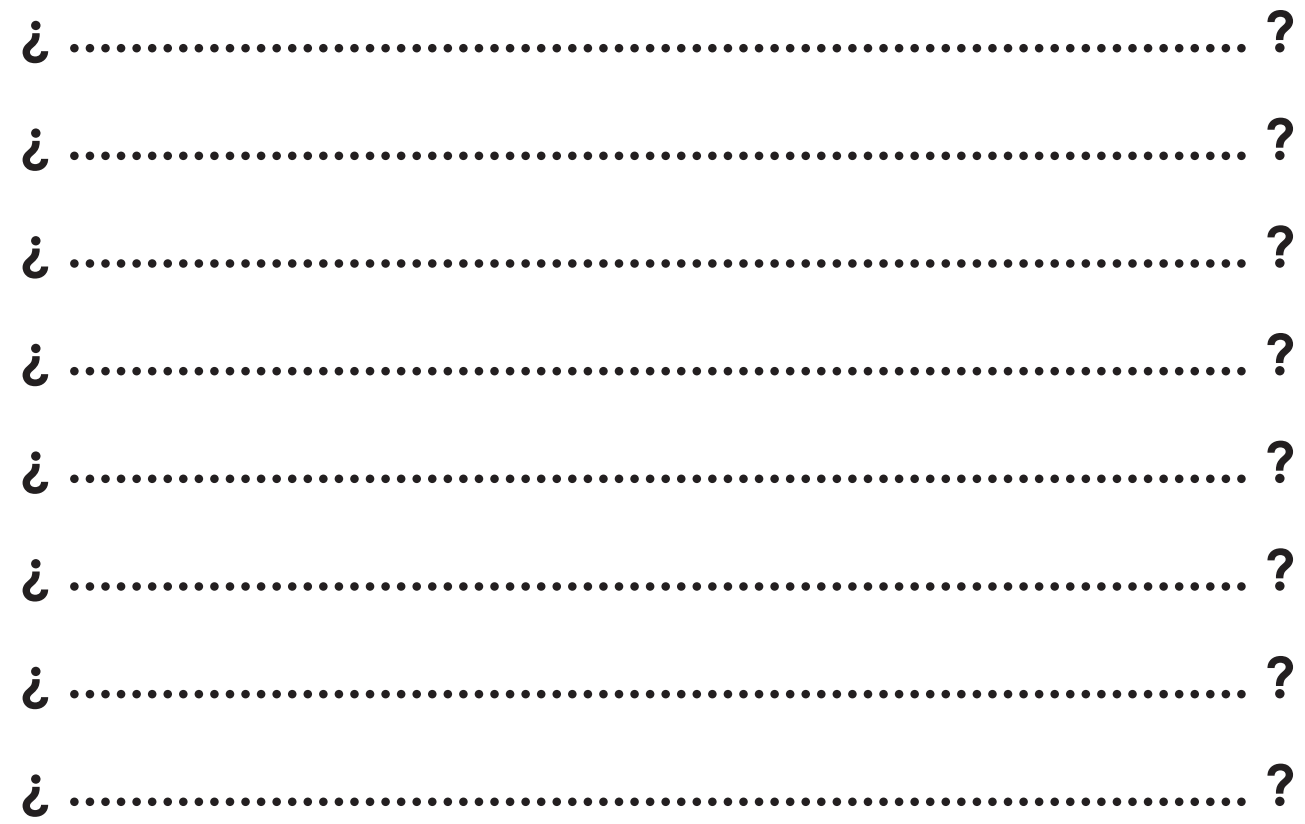




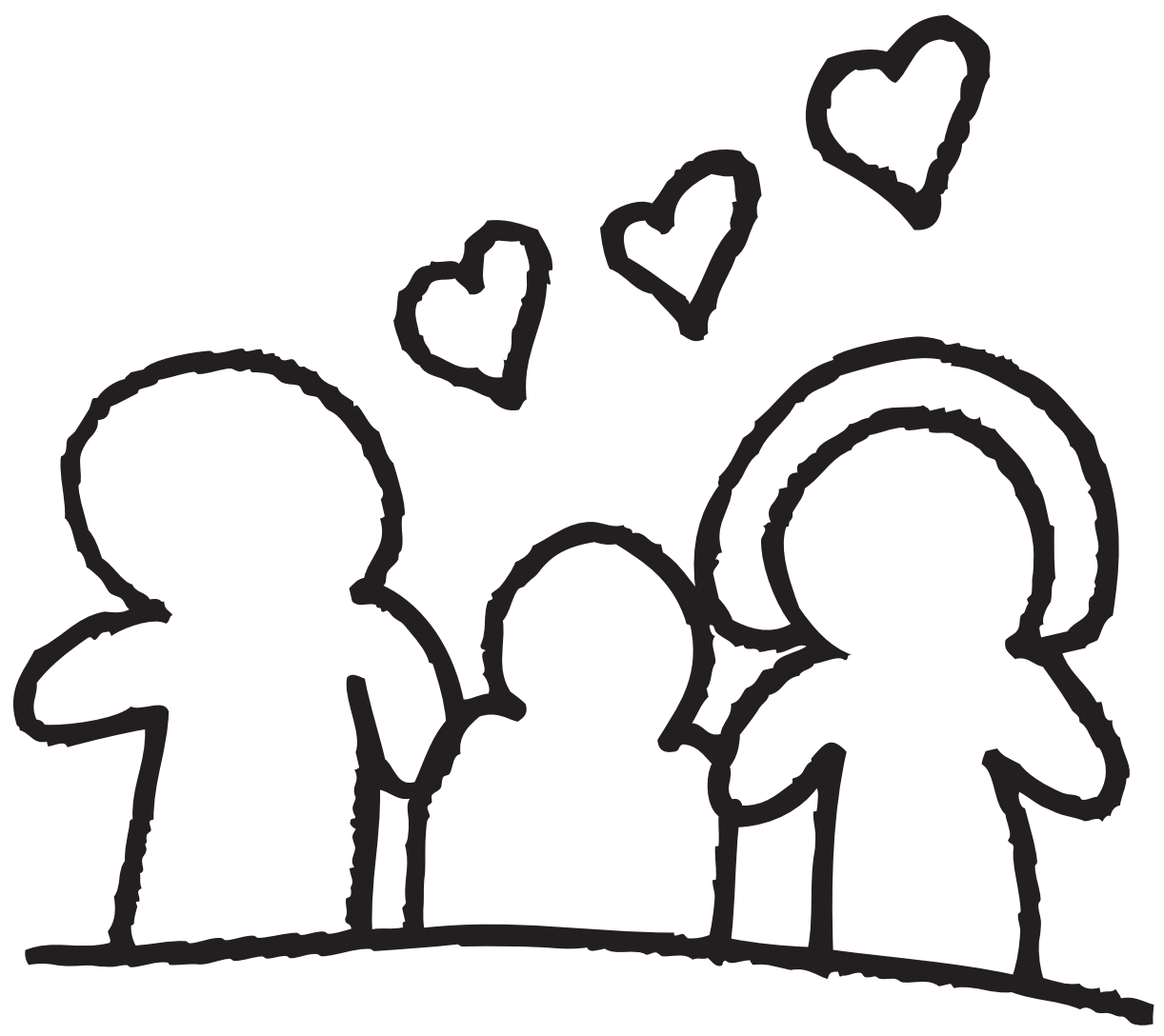

Siempre que puedas, intenta hacer cosas que te gustan: diviértete, ríe, sueña y, sobre todo vive feliz y ama a las personas que te rodean. 


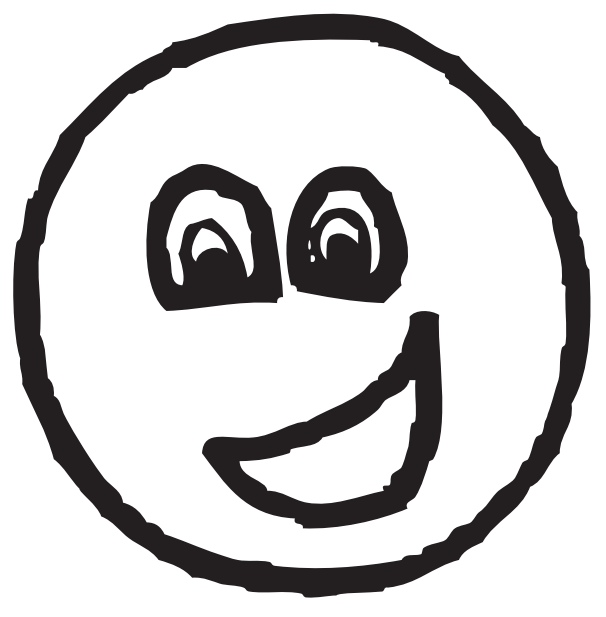

\section{Recuerda que siempre contarás con el apoyo de tu familia y de muchas personas que te quieren}

Busca ayuda si te sientes solo 



\section{LECTURAS}





\title{
CUENTOS Y RELATOS
}

\author{
Cuando cuentes cuentos, \\ cuenta cuántos cuentas, \\ cuenta porque, \\ cuando cuentas cuentos \\ nunca cuentas \\ cuántos cuentos cuentas
}

\section{DE CÓMO CADA CUAL RECIBIÓ SU MORADA ${ }^{1}$}

En el principio no había nada. Ni cuevas, ni barrancos, ni pájaros, ni estrellas. No había luz, no soplaba el viento, no se oía ruido alguno. Había soledad, oscuridad, silencio.

En el principio solo existían Tepeu y Gucumatz: ocultos, bajo unas hermosas plumas verde - azul, ligerísimas. Eran los progenitores. Estaban solos, detenidos y flotantes, sin cosa alguna que ver, sin voces a su alrededor, sin nadie que los acompañara. Estaban envueltos en silencio. Fue por eso que, un buen día, tomaron una sola y misma determinación: icomenzarían al unísono la creación del mundo!

Llenos de firmeza, los progenitores juntaron su pensamiento, reunieron sus voluntades y dijeron: "TIERRA". Y al golpe de su voz contra el silencio, surgieron por primera vez cavernas, abismos, desiertos y montañas: apareció la tierra ante sus ojos. Los progenitores sonrieron.

En cuanto comprobaron que su creación, además de aparecer permanecía, cuando vieron que su obra era duradera, volvieron a reunir su pensamiento y con viva voz dijeron: "viento, fuego, agua, bosques, plantas, animales".

\footnotetext{
${ }^{1}$ Consejo Nacional de Población (1999). Familia. México. El Popol-vuh es un libro sagrado del pueblo maya. En él aparecen momentos de creación, relatos históricos o descripciones de paisajes. Sus textos nos ofrecen imágenes muy bellas, platicadas con lenguajes campesinos, sencillos, llenos de color y de fuerza. El relato que aquí presentamos es una versión libre de algunas de las primeras páginas de este libro maya (nota del editor).
} 
El primero en aparecer fue el viento, que corrió sobre la tierra con toda la energía y el asombro de un recién nacido y contempló en su carrera el surgimiento de la vida: mares, milpas, venados, lava incandescente y arroyos de montaña. El campo se llenó de movimiento, los árboles sacudieron orgullosos sus melenas con ayuda del aire y el océano se llenó de perlas y corales. El bullicio subió y alcanzó el corazón de los progenitores.

- No es bueno que nuestras criaturas vaguen por la tierra - dijeron Tepu y Gucumatz, cobijándose bajo sus maravillosas plumas de colores - Tenemos que buscarles hogares, para que vivan en familias.

$Y$, con la creatividad que tienen todos los progenitores, fueron asignando a cada especie una vivienda diferente, confortable y alegre. Los árboles bulleron con el salto de pájaros y ardillas. Entre las aguas del lago asomaron los peces. Los puerco espines buscaron sus habitaciones entre los barrancos.

Los pastos se regocijaron al ver llegar a los grillos. Los venados marcharon majestuosos, en parejas, por los senderos del bosque.

iQué inmensa fue la alegría de los progenitores! iCuánta satisfacción sintieron al ver a sus criaturas acompañadas, seguras y contentas! Su creación era buena. 


\section{EL CAMBIO ${ }^{2}$}

iHola!

Soy Jiternura, una jirafa. Mi amor y mi ternura son tan grandes como mi cuello; aunque estos sentimientos van creciendo conforme tengo amigos como tú.

El cambio es un tema muy interesante y divertido. Voy a hablarte del cambio que existe dentro de nosotros cuando queremos hacer las cosas bien. Mira...

Hay momentos en que las cosas que hacemos no nos salen bien; esto provoca que nos desesperemos y lleguemos a enojarnos.

Precisamente aquí llega el cambio del que hablo. Si te enojas porque no te salen bien las cosas, "cambia" tu modo de pensar, pues cuando uno está enojado no puede razonar.

Si en lugar de enojarte observas y te preguntas por qué no has podido realizarlo, verás que podrás solucionar el problema.

Cambiar el enojo por la calma y la observación nos trae solución. Porque por medio de la observación tenemos la calma para analizar y conocer la causa. Entonces sí ia realizar lo que queríamos!

Cuando estés en un momento malo, y te sientas pesimista, aburrido o cansado, cambia tu actitud y tus pensamientos y lograrás dar el primer paso hacia lo positivo.

Tú puedes cambiar tus estados de ánimo. Poniendo amor, alegría, 
entusiasmo a tu vida y asumiendo una actitud positiva.

Las cosas se ven según las pienses. Por ejemplo: un día común y corriente puede ser para los pesimistas el día más triste. Para otros que ponen entusiasmo y amor a sus actos, puede llegar a ser el día más bello y alegre; sin embargo, el día es el mismo en ambos casos.

Tú escoges cómo quieres que sean tus días, alegres o tristes. Nosotros queremos lo mejor para ti.

Por eso, cuando veas a un amigo triste o pesimista, hazlo sonreír para que "cambie" su estado de ánimo y se sienta contento.

Procura mantener esa alegría siempre que puedas; pues las personas que conviven contigo, al verte alegre y entusiasta, se contagiarán de tu alegría y todos estarán felices.

Ten cuidado de no perder esa alegría, ya que así como podemos cambiar a lo positivo, también, si nos descuidamos, podemos sentirnos tristes o pesimistas.

$\mathrm{Si}$ esto te sucediera vuelve a cambiar tu estado de ánimo con pensamientos positivos combinados con amor, comprensión y entusiasmo.

Si intentamos mantener esa alegría y entusiasmo todo el día, lograremos hacer las cosas mejor y seguiremos teniendo más y más amigos.

¿No crees? 
FRANCISCA Y LA MUERTE ${ }^{3}$

(Onelio Jorge Cardoso)

-Santos y buenos días - dijo la muerte, y ninguno de los presentes la pudo reconocer.

iClaro!, venía la parca con su trenza retorcida bajo el sombrero y su mano amarilla en el bolsillo.

-Si no molesto — dijo—, quisiera saber dónde vive la señora Francisca.

-Pues mire -le respondieron, y asomándose a la puerta, un hombre señaló con su dedo rudo de labrador:

Allá por los matorrales que bate el viento, ¿ve? hay un camino que sube la colina. Arriba hallará la casa.

"Cumplida está" pensó la muerte, y dando las gracias echó a andar por el camino aquella mañana que, precisamente, había pocas nubes en el cielo y todo el azul resplandecía de luz.

Andando pues, miró la muerte la hora y vio que eran las siete de la mañana. Para la una y cuarto, pasado el meridiano, estaba en su lista cumplida ya la señora Francisca.

"Menos mal, poco trabajo; un solo caso", se dijo satisfecha de no fatigarse la muerte y siguió su paso, metiéndose ahora por el camino apretado de romerillo y rocío.

Efectivamente, era el mes de mayo y con los aguaceros caídos no hubo semilla silvestre ni brote que se quedara bajo tierra sin salir al sol. Los retoños de las ceibas eran pura caoba transparente. El tronco del guayabo soltaba, a espacios, la corteza, dejando ver la carne limpia de la madera. Los cañaverales no tenían una sola hoja amarilla; verde era todo, desde el suelo al aire, y un olor a vida subía de las flores.

${ }^{3} \mathrm{http}: / /$ bibliotecadigital.ilce.edu.mx/sites/colibri/cuentos/francisca/htm/sec_2.htm 
Natural que la muerte se tapara la nariz. Lógico también que ni siquiera mirara tanta rama llena de nidos, ni tanta abeja con su flor. Pero ¿qué hacer?; estaba la muerte de paso por aquí, sin ser su reino.

Así pues, echó y echó a andar la muerte por los caminos hasta llegar a casa de Francisca.

-Por favor, con Panchita -dijo adulona la muerte.

-Abuela salió temprano

- contestó una nieta de oro, un poco temerosa, aunque la parca seguía con su trenza bajo el sombrero y la mano en el bolsillo.

- ¿Y a qué hora regresa?

-preguntó la muerte.

—iQuién lo sabe! —dijo la madre de la niña—. Depende de los quehaceres. Por el campo anda, trabajando.

Y la muerte se mordió el labio. No era para menos seguir dando rueda por tanto mundo bonito y ajeno.

- Hace mucho sol. ¿Puedo esperarla aquí?

-Aquí quien viene tiene su casa. Pero puede que ella no regrese hasta el anochecer.

"iChin!", pensó la muerte, "se me irá el tren de las cinco. No; mejor voy a buscarla". Y levantando su voz, dijo la muerte:

—¿¿ónde, de fijo, pudiera encontrarla ahora?

—De madrugada salió a ordeñar. Seguramente estará en el maíz, sembrando.

— ¿Y dónde está el maizal? -preguntó la muerte.

- Siga la cerca y luego verá el campo arado detrás.

—Gracias — dijo secamente la muerte y echó a andar de nuevo. 
Pero miró todo el extenso campo arado y no había un alma en él. Sólo garzas. Soltóse la trenza la muerte y rabió:

"iVieja andariega, dónde te habrás metido!" Escupió y continuó su sendero sin tino. Una hora después de tener la trenza ardida bajo el sombrero y la nariz repugnada de tanto olor a hierba nueva, la muerte se topó con un caminante:

-Señor, ¿pudiera usted decirme dónde está Francisca por estos campos? - Tiene suerte — dijo el caminante-, media hora lleva en casa de los Noriega. Está el niño enfermo y ella fue a sobarle el vientre. —Gracias — dijo la muerte como un disparo, y apretó el paso.

Duro y fatigoso era el camino. Además, ahora tenía que hacerlo sobre un nuevo terreno arado, sin trillo, y ya se sabe cómo es de incómodo sentar el pie sobre el suelo irregular y tan esponjoso de frescura, que se pierde la mitad del esfuerzo. Así por tanto, llegó la muerte hecha una lástima a casa de los Noriega:

-Con Francisca, a ver si me hace el favor.

-Ya se marchó.

—iPero, cómo! ¿Así, tan de pronto?

—¿Por qué tan de pronto? -le respondieron-.

Sólo vino a ayudarnos con el niño y ya lo hizo. ¿De qué extrañarse?

—Bueno... verá — dijo la muerte turbada -, es que siempre una hace la sobremesa en todo, digo yo.

-Entonces usted no conoce a Francisca.

-Tengo sus señas — dijo burocrática la impía.

- A ver; dígalas —esperó la madre. Y la muerte dijo:

- Pues... con arrugas; desde luego ya son sesenta años...

- ¿Y qué más? 
-Verá... el pelo blanco... casi ningún diente propio... la nariz, digamos... —¿Digamos qué?

-Filosa.

- ¿Eso es todo?

—Bueno... además de nombre y dos apellidos.

-Pero usted no ha hablado de sus ojos.

—Bien; nublados... sí, nublados han de ser... ahumados por los años.

-No, no la conoce - dijo la mujer-.

Todo lo dicho está bien, pero no los ojos. Tiene menos tiempo en la mirada. Ésa, a quien usted busca, no es Francisca.

Y salió la muerte otra vez al camino. Iba ahora indignada sin preocuparse mucho por la mano y la trenza, que medio se le asomaba bajo el ala del sombrero. Anduvo y anduvo. En casa de los González le dijeron que estaba Francisca a un tiro de ojo de allí, cortando pastura para la vaca de los nietos. Mas sólo vio la muerte la pastura recién cortada y nada de Francisca, ni siquiera la huella menuda de su paso. Entonces la muerte, quien ya tenía los pies hinchados dentro de los botines enlodados, y la camisa negra, más que sudada, sacó su reloj y consultó la hora:

"iDios! iLas cuatro y media! iImposible! iSe me va el tren!"

Y echó la muerte de regreso, maldiciendo.

Mientras, a dos kilómetros de allí, Francisca escardaba de malas hierbas el jardincito de la escuela. Un viejo conocido pasó a caballo y, sonriéndole, le echó a su manera el saludo cariñoso:

—Francisca, ¿cuándo te vas a morir? 
Ella se incorporó asomando medio cuerpo sobre las rosas y le devolvió el saludo alegre:

—Nunca —dijo—, siempre hay algo que hacer.

\section{CONSERVACIÓN DE LOS RECUERDOS 4}

Los famas para conservar sus recuerdos proceden a embalsamarlos en la siguiente forma: luego de fijado el recuerdo con pelos y señales, lo envuelven de pies a cabeza con una sábana negra y lo colocan parado contra la pared de la sala, con un cartelito que dice: "excursión a Quilmes", o: "Frank Sinatra".

Los cronopios, en cambio, esos seres desordenados y tibios, dejan los recuerdos sueltos por la casa entre alegres gritos, y ellos andan por el medio y cuando pasa corriendo uno, lo acarician con suavidad y le dicen: "no vayas a lastimarte", y también: "cuidado con los escalones". Es por eso que las casas de los famas son desordenadas y silenciosas, mientras en las de los cronopios hay gran bulla y puertas que golpean. Los vecinos se quejan siempre de los cronopios, y los famas mueven la cabeza comprensivamente y van a ver si las etiquetas están todas en su sitio.

\footnotetext{
${ }^{4}$ Julio Cortázar (1974). Historia de cronopios y de famas. Buenos Aires; Minotauro, 9a edición.
} 


\section{FÁBULAS, CANCIONES, RIMAS, RONDAS Y COPLAS ${ }^{5}$}

\section{EL ZAPATERO Y EL HERRADOR ${ }^{6}$}

Un herrador y un zapatero no lograban ser amigos. El herrador decía que el zapatero ponía la mano donde los demás ponían el pie, y el zapatero alegaba que el herrador andaba en las patas de los animales. Ambos, pues, encontraban sus respectivas ocupaciones superiores, una de la del otro, y se miraban con idéntico desprecio.

Un día el herrador advirtió que la suela de su zapato estaba rota, y colocó un cartón como plantilla, para no llevarlo al zapatero, aunque andaba muy incómodo. Casi al mismo tiempo, el zapatero tuvo que ir a otro pueblo cercano y se dio cuenta de que su caballo tenía algún defecto en una herradura que no le permitía caminar bien. Como el zapatero no podía remediar el mal de su caballo como el herrador había hecho con su zapato, se dirigió a la casa del herrador, contra toda su voluntad.

El zapatero se sorprendió mucho al encontrar amabilidad en el herrador, quien, diligente, procedió a dejar listo su caballo y cuando terminó, se quitó el zapato roto y lo mostró al zapatero. Éste rió de buena gana. Al día siguiente puso suelas nuevas en los zapatos del herrador. Los dos se despidieron estrechándose las manos.

Algún día, en algún momento, necesitamos de los demás.

El hombre siempre necesita del hombre.

\footnotetext{
${ }^{5}$ Jacob Esther (1987). Así cuentan y juegan en la Huasteca. México; Consejo Nacional de Fomento Educativo y Jacob Esther y Ramírez Granados A. (1984). Cuántos cuentos cuentan... México; Consejo Nacional de Fomento Educativo.

${ }^{6}$ Perea María Luz y Rosas Moreno José (1985). Fábulas Mexicanas. México; Diana. p. 58
} 


\section{MATEMÁTICAS, LA CIENCIA}

- Matemáticas, la ciencia

que me quita la paciencia

— ¿Verdad que sí?

- Sí

- ¿Verdad que no?

- No

— ¿Verdad que tú te quieres salir de aquí?

- Sí

\section{LAS CAFETERAS}

Seis, seis, seis,

seiscientos sesenta y seis.

Arriba las cafeteras, las cafeteras de café;

con el tínguili, tínguili, tínguili, con el tóngolo, tóngolo, tóngolo.

Ay mamá, qué bien te ves con ese vestido

que traes al revés.

Su ma, su ma, su máquina de coser,

la tu, la tu, la tuve que componer.

Gracias hijita, por tu quehacer, que salga la niña que va a perder. 


\section{MARIACUMBÉ}

El pillo le dijo al guardia

y el guardia le dijo al juez,

que en dónde estará el negrito

que siempre baila mariacumbé.

Y baila negrito, baila

y baila mariacumbé

y mira si no lo bailas

que pamba te daré.

Que dé la media vuelta para ver quién fue.

$\mathrm{Y}$ baila morena, baila

y baila mariacumbé,

y mira si no lo bailas

que panzazo te daré.

Anoche yo te vi

vestida de tulipán

moviendo la cintura,

parapapán, pan, pan. 


\section{LA BARCA}

Se va y se va la barca, se va, se va el vapor; el lunes por la mañana, también se va mi amor. Me levanto tempranito, me voy derecho a la mar, a preguntarle a las olas, que si lo vieron pasar, con un ramito de flores jamás lo puedo olvidar. Si el cielo fuera tinta, si el cielo fuera papel, le escribiría una carta a mi querido Manuel.

\section{Yo SoY}

(Copla popular)

Yo soy como las tortugas

que tienen su concha de acero:

al tiempo le doy su tiempo;

si rueda el mundo, nomás lo veo.

Yo soy nacido en el campo,

y no lo niego, señores, porque en el campo es que nacen los pájaros cantores. 
COPLAS DE ANIMALES

En la cumbre de un cardón cantaban tres animales, uno parecía gorrión y los otros cardenales; iay! Qué parecidos son, pero nunca son iguales.

En medio del árbol canta el pájaro cuando llueve, y canta con la garganta cuando el corazón le duele; también de dolor se canta cuando llorar no se puede.

\section{COPLA CHISTOSA}

En las ramas de un café estaba sentado un pato, si porque me encuentro flaco ya no me conoce usted, yo soy aquel mismo gato, nomás que me revolqué.

\section{YA CON ESTA ME DESPIDO}

Voy a dar la despedida como la da un marinero, con su sombrero en la mano: "Hasta luego, compañero". 


\section{ADIVINANZAS Y REFRANES}

\section{ADIVINA, ADIVINADOR... ${ }^{7}$}

Te haré una pregunta sola, para no serte molesto:

lee y contéstame esto.

¿Qué animal come con la cola?

\section{ADIVINA, ADIVINADOR... 8}

Camisita verde

que al abrirse

caliente o fría

sale el dulce rojo

del san día.

\section{ADIVINA, ADIVINADOR... 9}

Pensando me estoy, pensando;

pensando me vuelvo loca

con la suegra de mi cuñada.

¿Qué parentesco me toca?

\section{ADIVINA, ADIVINADOR... 10}

Una señorita

muy aseñorada,

llena de remiendos

y sin ninguna puntada.

\footnotetext{
7 Respuesta: Todos, porque ninguno se la quita para comer.

8 Respuesta: La sandía

9 Respuesta: Mi madre

${ }^{10}$ Respuesta: La gallina
} 


\section{REFRANES POPULARES}

- Cuando una puerta se cierra, otro ciento se abren

- El que algo quiere, algo le cuesta

- El que da primero da dos veces

- El que mucho aprieta, poco abarca

- El que no sabe, es como el que no ve

- El que no tiene cabeza, tiene que tener pies

- El sabio siempre quiere aprender, el ignorante siempre quiere enseñar

- El tiempo todo lo cura y todo lo muda

- Errar es de humanos, perdonar es de sabios

- Jugar y nunca perder, jamás puede ser

- Los duelos con pan son menos

- No hay mal que por bien no venga

- Muchos pocos hacen un mucho

- Nadie sabe lo que tiene hasta que lo pierde

- No hay bien que dure ni mal que no se acabe

- Quien hace lo que puede no está obligado a más

- Un dedo no hace mano, pero sí con sus hermanos 


\section{POESÍA}

\section{EL PLACER CUESTA ${ }^{11}$}

Mil gotas de rocío

vierte la aurora,

para que en el valle

brote una rosa.

Así a las almas

siempre un placer les cuesta

miles de lágrimas.

\section{EN PAZ}

(Amado Nervo)

Muy cerca de mi ocaso, yo te bendigo, vida, porque nunca me diste ni esperanza fallida, ni trabajos injustos, ni pena inmerecida; porque veo al final de mi rudo camino que yo fui el arquitecto de mi propio destino; que si extraje la miel o la hiel de las cosas, fue porque en ellas puse hiel o mieles sabrosas: cuando planté rosales, coseché siempre rosas. ...Cierto, a mis lozanías va a seguir el invierno: imas tú no me dijiste que mayo fuese eterno! Hallé sin duda largas las noches de mis penas; mas no me prometiste tan sólo noches buenas; y en cambio tuve algunas santamente serenas... Amé, fui amado, el sol acarició mi faz.

iVida, nada me debes! iVida, estamos en paz! 


\section{AGUA DE TABASCO}

(Carlos Pellicer)

Agua de Tabasco vengo

y agua de Tabasco voy.

De agua hermosa es mi abolengo

y es por eso que aquí estoy

dichoso con lo que tengo.

\section{SOLIDARIDAD}

(Amado Nervo)

Alondra, ivamos a cantar!

Cascada, ivamos a saltar!

Riachuelo, ivamos a correr!

Diamante, ivamos a brillar!

Águila, ivamos a volar!

Aurora, ivamos a nacer!

iA cantar!

iA saltar!

iA correr!

iA brillar!

iA volar!

iA nacer! 


\section{TRADICIONES}

\section{EL ALTAR DE MUERTOS ${ }^{12}$}

"Mi madre, te espero me vienes a saludar este día

Te ofrezco sólo hasta donde se puede, tú me dispensarás Esta ofrenda la pongo aquí, una torta de pan para que allá todas las ánimas benditas se repartan Si vivimos el año que viene los esperamos y si no nomás hay, en vida nos estamos cambiando"

Invocación de una anciana de San Gregorio, Atlapulco.

La tradición de la ofrenda y los altares a los muertos la encontramos en muchos lugares del país, cada uno con matices propios.

Sin embargo, los investigadores señalan características comunes en todos ellos encontrando con certeza que el culto a los muertos en algunas poblaciones, - como Mixquic, Chenal Xo, Janitzio y otros -, constituye una actividad social, ingrediente sustancial para la función ideológica del grupo. Este culto, tengámoslo claro, no se reduce al día 2 de noviembre, sino que se manifiesta durante todo el año.

Para los pueblos que recogen la tradición prehispánica, religión, muerte y muertos son una sola realidad. Esta tradición se conjuga sincréticamente con las formas populares de la religiosidad católica. La creencia en otra vida -tanto prehispánica como cristiana -, hace que la muerte sea la principal motivación para la religiosidad; morir es una posible creación de la vida.

Los hallazgos arqueológicos en México nos han demostrado que en los enterramientos de nuestros antepasados se incluían objetos para que el difunto se encuentre con lo necesario y con comodidad en un más allá. 
Respecto al camino hacia ese "más allá", algunas comunidades especifican en su tradición las características que los difuntos encontrarán.

En Mixquic, por ejemplo, de acuerdo a legados nahuas, los recién muertos tendrán que cruzar un río caudaloso. Un perro antropomórfico los ayudará. Después el camino será largo y deberán contar con los suficientes víveres para llegar.

Esta creencia de que las ánimas se van a un "más allá" sigue siendo la motivación para ofrendar a los muertos. Si bien habíamos señalado que el culto a los muertos se manifiesta durante todo el año en los enterramientos, visitas a los cementerios, etc., es durante el $1^{\circ}$ y 2 de noviembre que cobra especial importancia; dejando de lado las características especiales de cada grupo, es común la creencia de que los muertos "visitan a sus parientes" en estas fechas y les gusta "encontrar fiesta"; vienen del "más allá" para luego regresar.

En estos días, se altera la vida cotidiana de la comunidad: las mujeres preparan los alimentos que van a ofrendar y los hombres ayudan al arreglo en general. En algunos lugares se elabora un altar familiar y se prende una veladora por cada difunto. En la ofrenda se incluye, además de la comida y bebida predilecta del difunto, sus herramientas de trabajo y objetos favoritos que le pertenecieron en vida.

Cuando el difunto es niño se agregan también dulces y juguetes. En Mixquic sucede además que hay una diferencia entre la ofrenda del recién fallecido, puesto que va al "más allá", y el que ya tiene tiempo, es decir, que ya es un "llegado" y está en el "nivel superior", no necesita más de utensilios y alimentos para su caminar.

Algunas comunidades incluyen los retratos de los difuntos en el altar. Los Chontales que habitan en la zona de Tabasco colocan imágenes de los santos a los que son devotos y los rezanderos y jefes de familia juegan un 
rol importante en el rito de ofrendar.

Los muertos vienen y es necesario ayudarles a llegar a su casa. Se colocan faroles en los pórticos, luces en las calles o fogatas en el camino. Aspirarán el "aroma" de lo que se les ha ofrendado y regresarán satisfechos y contentos con los suyos que aún siguen en este mundo.

Pero, ¿qué pasa si las familias desatienden a sus muertos?... A decir de los informantes de distintas comunidades, si los difuntos al venir no encuentran que se les ha ofrendado, se disgustan: entonces no protegerán a los suyos a lo largo del año; les vendrán desgracias de tipo económico o físico. Los muertos se convierten entonces en malos espíritus que maldicen a quienes no los han honrado.

Nos cuenta un informante de Culiapan:

"...pasó de que un señor lo llevaba a relajo pues en estos días en lugar de adornar su altar, anduvo por el cerro cortando palos para carbón. Qué va a venir el muerto dijo. Como que se burló, pues agarró un adobe y lo puso en su altar, y se fue p'al monte. Una vez allí, cuando cortando estaba el palo, oyó voces como de gentes que regresaban de Culiapan: ¿Cómo te fue?, dijo una voz, pues si vieras que me fue muy mal, pues no encontré nada en mi casa, tan sólo encontré un adobe en el altar, por eso me voy muy triste. A mí me recibieron muy contento, volvió a hablar la primera voz, por eso me llevo mucho aroma: no te preocupes, yo te convido. Pero aún así, triste se quedó aquella alma. Después de lo que oyó el señor que cortaba palos dijo: ¿Pues qué sería mi papá?, y desde esa hora ya no cortó leña, y luego se vino a adornar su casa: pero pa' que sirvió si ya todo había pasado, ya no tenía caso". 
Otros relatos nos hablan de la necesidad de ofrendar a los muertos para obtener su protección en las cosechas, armonía familiar, provechos económicos, etc. Podríamos decir que la organización social de los vivos se sujeta en esos días al gobierno de los muertos. Entre los Tzotziles, por ejemplo, se constituye un Ayuntamiento especial que se compromete a vigilar los intereses de los muertos. De esta manera los muertos interactúan con los vivos; forman parte del equilibrio social y de la dinámica de la comunidad.

Los altares no son pues una costumbre caduca y sin sentido. Significan la necesidad de hacer presente a los muertos, de recordarlos, honrarlos y darles culto para que los vivos puedan seguir contando con la protección necesaria de sus seres queridos que están en un más allá.

Una de las representaciones más importantes del arte tradicional mexicano es, sin lugar a dudas, el grabado. Este cobró gran impulso con José Guadalupe Posada (1852-1913), artista genial que junto con el también genial Manuel Manilla inició la utilización de las calaveras, de las "calacas catrinas" para ilustrar los hechos que vivían y conmovían al pueblo: la dictadura de Porfirio Díaz, el inicio de la revolución, la aparición de un cometa, un terremoto, un crimen pasional o un chisme de comadres. Las calaveras de estos artistas expresaban, muy a lo vivo, el modo de la sociedad de una época.

Una vez más, y muchas veces más, las calaveras aparecen en noviembre. Las mismas calaveras de Manilla, de Posada y de Méndez, pero renovadas y vestidas de hoy, con las noticias de hoy, los políticos de hoy, el chisme y el desastre de hoy.

Una celebración más de la fiesta de los fieles difuntos, y una confirmación más de que la tradición de la calavera no se ha perdido en México. 


\section{LAS CALAVERAS 12}

I

Estaba la muerte un día

sentada en un arenal,

comiendo tortilla fría

pa'ver si podía engordar.

II

Estaba la media muerte

sentada en un tecomate,

diciéndole a los muchachos:

vengan, beban chocolate.

III

Estaba la muerte seca sentada en un carrizal, comiendo tortilla dura

y frijolitos sin sal

sin sal, sin sal...

12 De autor anónimo. Citadas por Jacob Esther y Ramírez Granados A. (1984). Cuántos cuentos cuentan... México; Consejo Nacional de Fomento Educativo, p. 59. 



\section{REFLEXIONES}

¿Quién dijo que leer es fácil? ¿Quién dijo que leer es contentura siempre y no riesgo y esfuerzo?

Precisamente porque no es fácil, es que convertirse en lector resulta una conquista

Graciela Montes 



\section{Ventajas de la lectura y escritura}

- Aumentan, enriquecen y aclaran el vocabulario y la memoria

- Participan en la aclaración de dudas sobre el significado de las palabras

- Mejoran y amplían las asociaciones de palabras a través de las metáforas

- Favorecen la creatividad y la enseñanza de valores en el contexto de las propias vivencias

- Fomentan la comunicación y el acercamiento con los adultos

- Promueven el pensamiento creativo y abstracto

- Permiten diferenciar lo fantástico de lo real y concreto

- Facilitan reconocer la influencia del mundo externo en el mundo interior

- Crean mapas mentales para organizar y comparar experiencias

- Se pueden experimentar emociones y desahogar conflictos, deseos y expectativas

- Se facilita el conocimiento y uso de la gramática

- Se puede relacionar el lenguaje oral con el lenguaje corporal

- Facilitan la relación y asociación entre objetos, acciones, funciones y resultados

- Capacitan para anticipar y proponer soluciones a problemas concretos

- Transforman los momentos de soledad en una lúdica compañía

- Se realizan como actos de conocimiento y de autoconocimiento 
(...) las necesidades emocionales básicas del niño son: la necesidad de sentirse seguro y protegido por los padres, la de ser amado y comprendido por ellos y la de tener oportunidades para expresar sus hostilidades y antagonismos para así aprender a manejarlos. También hay acuerdo en cuanto a que los principales temores del niño son el miedo a ser abandonado, el de no ser amado y el de ser dañado corporalmente.

\section{Juan Ramón de la Fuente ${ }^{1}$}

"Los textos", "las palabras, "las letras" de aquel contexto - en cuya percepción me probaba, y cuanto más lo hacía más aumentaba la capacidad de percibir - encarnaban una serie de cosas, de objetos, de señales, cuya comprensión yo iba aprendiendo en mi trato con ellos, en mis relaciones con mis hermanos mayores y con mis padres (...) "Los textos", "las palabras", "las letras" de aquel contexto se encarnaban en el canto de los pájaros, (...) en la danza de las copas de los árboles sopladas por fuertes vientos que anunciaban tempestades, truenos, relámpagos; las aguas de la lluvia jugando a la geografía, inventando lagos, islas, ríos, arroyos (...) "Los textos", "las palabras", "las letras" de aquel contexto se encarnaban también en el silbo del viento, en las nubes del cielo, en sus colores, en sus movimientos; en el color del follaje, en la forma de las hojas, en el aroma de las flores (...) en la densidad de los árboles, en la cáscara de las frutas...

(...) la lectura de la palabra, de la frase, de la oración, jamás significó una ruptura con la "lectura" del mundo. Con ella, la lectura de la palabra fue la lectura de la "palabra-mundo".

(...) la lectura del mundo precede siempre a la lectura de la palabra y la lectura de ésta implica la continuidad de la lectura de aquél.

"La importancia del acto de leer"

Paulo Freire ${ }^{2}$

${ }^{1}$ Citado por Calvillo Vaillard Aída M. G. (1996). Los niños hospitalizados. México; CNDH, p. 40

${ }^{2}$ Citado por Ladrón de Guevara Moisés (1985). La lectura. México; Caballito/SEP, pp. 22-23, 25, 29 
Ante una realidad extraordinaria, la conciencia toma el lugar de la imaginación

Paul Auster ${ }^{3}$

Cuando leemos para informarnos, obtenemos hechos. Cuando leemos para entender, no solamente aprendemos hechos sino también su significado.

Mientras se hallen ustedes en la etapa de aprendizaje de la lectura, tendrán que releer un libro más de una vez. Si éste es digno de ser leído tiene derecho a que lo lean por lo menos tres veces.

Moisés Ladrón de Guevara ${ }^{4}$

Cuando el padre muere (...) el hijo se convierte en su propio padre y en su propio hijo. Mira a su hijo y se ve a sí mismo reflejado en su rostro. Imagina lo que el niño ve cuando lo mira y se siente como si interpretara el papel de

su propio padre.

Memoria: el espacio en que una cosa ocurre por segunda vez.

(...) la vida de su hijo le importaba más que la suya, y si su propia muerte hubiera servido para salvar a su hijo, la habría aceptado sin dudar. Por lo tanto, justo en aquel momento de terror se había convertido, de una vez para siempre, en el padre de su hijo.

La invención de la soledad

Paul Auster ${ }^{5}$

${ }^{3}$ Auster Paul (1994). La invención de la soledad. México; Anagrama, p. 115

${ }^{4}$ Ladrón de Guevara, Moisés (1985). La lectura. México; Caballito/SEP, pp. 58, 68

${ }^{5}$ Auster Paul (1994). La invención de la soledad. México; Anagrama, pp. 115, 118 
(...) La vida del niño presenta dos aspectos: uno es el cuidado y la responsabilidad absolutamente necesarios para la conservación de la vida del niño y su crecimiento. El otro aspecto va más allá de la mera conservación. Es la actitud que inculca en el niño el amor a la vida, que crea en él el sentimiento: es bueno estar vivo, es bueno ser una criatura, es bueno estar sobre esta tierra.

El arte de amar

Erich From ${ }^{6}$

(...) Una lectura estimulante o simplemente que lo transporte a regiones de ilusión haciéndole olvidar su dolor, o tratados técnicos que interesen al doliente y que le ayuden a pasar la vacación forzada y de sufrimiento en la noble ambición de recordar y mejorar su oficio.

Álvaro Pascual Leone 7

(...) es a manera de un aprendizaje dispuesto por la naturaleza para que se enseñen a desahogar el sufrimiento. Mas el llanto que no puede salir, ese que no tiene fuerza; ese que se va empalideciendo y apagando los ojos del niño pobre, enfermo, triste, es el que enternece más intensamente.

Los niños tristes

\section{Fernando Tola de Habich ${ }^{8}$}

(...) al tener conciencia de su actividad y del mundo en que se encuentran, al actuar en función de finalidades que les proponen y se proponen, al tener el punto de decisión de la búsqueda de sí y en sus relaciones con el mundo y con los otros, al impregnar el mundo de su presencia creadora a través de la transformación que en él realizan.

Pedagogía del oprimido

Paulo Freire 9

${ }^{6}$ Citado por Calvillo Vaillard Aída M. G. (1996). Los niños hospitalizados. México; CNDH, p. 42

${ }^{7}$ Citado por Calvillo Vaillard; Op. cit. p.45

${ }^{8}$ Citado por Calvillo Vaillard; Op. cit. p. 48

${ }^{9}$ Citado por Calvillo Vaillard; Op. cit. p. 48 
(...) el niño que crece no encuentra el camino hacia la madurez, despojado de obstáculos y dificultades. Las etapas que ha de cubrir, los objetivos que a cada momento reclama como condiciones necesarias para dar un paso en su desarrollo, son situaciones en las que se pone en juego todo lo que es, y este hecho repercute de forma global en su conducta. En este sentido, la acción educativa debe bloquear los aspectos negativos del desarrollo y fomentar los aspectos positivos. Es tarea del educador preparar las reacciones del educando en un clima en el que éste comience a relacionar lo psicológico con lo que terminará siendo estrictamente humano como expresión global.

"La educación como proceso" Alejandrino Castañeda Vélez ${ }^{10}$

(...) la vida afectiva y la vida cognoscitiva son inseparables. Lo son porque todo intercambio con el medio supone a la vez una estructura y una valorización. No se podría razonar incluso en matemáticas puras sin experimentar sentimientos y, a la inversa, no existen afecciones que no se hallen acompañadas de un mínimo de comprensión o de discriminación.

Seis estudios de psicología Jean Piaget ${ }^{11}$

(...) en ciertos casos el afecto regula las energías de los actos y la estructura intelectual determina las técnicas $y$, en otros, los procesos intelectuales determinan la capacidad de receptividad emocional; sin embargo (...) el afecto y el intelecto son como dos caras de una moneda, ambos van siempre unidos y además contribuyen a la adaptación al ambiente.

Henry Wallon ${ }^{12}$

\footnotetext{
${ }^{10}$ Citado por Calvillo Vaillard Aída M. G. (1996). Los niños hospitalizados. México; CNDH, p.56

${ }^{11}$ Citado por Calvillo Vaillard; Op. cit. p.61

${ }^{12}$ Citado por Calvillo Vaillard; Op. cit. p.61
} 
(...) cada vez que el niño arma un rompecabezas, dibuja un coche, realiza una tarea, se siente satisfecho, feliz por el hecho de descubrir, de aprender, y obtiene una seguridad que ocasiona nuevos intentos y nuevos logros (...) Cuando un niño realiza una acción con éxito se siente capaz de repetirla eficientemente, de modificarla, de crear.

\section{Ma. Teresa Alonso Palacios ${ }^{13}$}

(...) el niño y el hombre necesitan un baño diario en las aguas de la imaginación y la fantasía. Desde que el niño comienza dividida su vida lúdica por la incorporación de las actividades funcionales en su mundo, el contacto con la fantasía, con la ficción, con la imaginación creadora se vuelve una necesidad perentoria, ineludible, vital y vitalizante.

"La lectura y el tiempo libre"

Juan Carlos Merlo ${ }^{14}$

(...) no podréis preparar a vuestros alumnos para que construyan mañana el mundo de sus sueños si vosotros ya no creéis en estos sueños; no podréis prepararlos para la vida si no creéis en ella; no podríais mostrar el camino su os habéis sentado, cansados y desalentados, en la encrucijada de los caminos.

Fernando Jiménez Mier y Terán ${ }^{15}$

(...) debe ser auténtico y propiciar una relación personal sincera con el niño para crear lazos de afecto, confianza, aceptación y, así, favorecer la interacción positiva (...) el éxito del aprendizaje depende, en gran parte, de un conductor que establezca las mejores condiciones para favorecer el acto educativo; que reconozca y estimule los logros de los niños; que propicie un ambiente abierto al diálogo, la espontaneidad y la comprensión con objeto de que el niño participe, descubra, investigue y ejerza su capacidad de crítica, elección y creación.

Ma. Teresa Alonso Palacios ${ }^{16}$

${ }^{13}$ Citado por Calvillo Vaillard Aída M. G. (1996). Los niños hospitalizados. México; CNDH, p.62

${ }^{14}$ Citado por Calvillo Vaillard; Op. cit. p.65

${ }^{15}$ Citado por Calvillo Vaillard; Op. cit. p.70

${ }^{16}$ Citado por Calvillo Vaillard; Op. cit. p.70 
Allí esta el mundo y las cosas que uno encuentra en él, de modo que hablar de ellas es pertenecer a ese mundo.

(...) imaginar un mundo sin consuelo es monstruoso.

La necesidad de relatos de un niño es tan fundamental como su necesidad de comida y se manifiesta del mismo modo que el hambre.

(...) el lenguaje, por lo tanto, no es una simple lista de objetos distintos a añadir, cuya suma total equivale al mundo. Por el contrario, tal como aparece en el diccionario, el lenguaje es un organismo infinitamente complejo, cuyos elementos - células y tendones, corpúsculos y huesos, dedos y fluidos están presentes en el mundo de forma simultánea y ninguno de ellos puede existir por sí solo; pues cada palabra es definida por otras, lo que implica que penetrar en cualquier parte del lenguaje es penetrar en su totalidad.

El lenguaje escrito nos libera de la necesidad de recordar demasiadas cosas, pues los recuerdos se almacenan en forma de palabras.

La invención de la soledad

Paul Auster ${ }^{17}$

${ }^{17}$ Auster Paul (1994). La invención de la soledad. México; Anagrama, pp. 209, 228 y 235 
El artista, el poeta, es sobre todo artífice, el que, con arte, hace algo nuevo, algo que antes no estaba. (p. 25)

Jugar nos ayudaba a entender la vida, y también el arte nos ayuda a entender la vida. (p. 28)

Un cuento es siempre, a la vez, lo más natural y lo más extraño (...) también en los dibujos está el cuento (...) el cuento esta hecho de palabras, y por eso es una ilusión tan especial. En realidad una ilusión doble, que monta una ilusión sobre otra. Un cuento es un universo de discurso imaginario... un juego con sus reglas. (p. 45-46)

Las ideas me ayudaron a ordenar el mundo. La literatura me hace sentir que el mundo está siempre ahí, ofreciéndose, no horadado y disponible, que siempre se puede empezar de nuevo. (p. 63)

El que escribe, como el niño que juega, busca. Busca construirse. Ensaya formas de dominio sobre el universo de las palabras, que le ofrecen resistencia, del mismo modo en que el niño que juega ensaya sus dominios, construye lo propio y trata de domesticar al mundo. (p. 83)

La frontera indómita Graciela Montes ${ }^{18}$

${ }^{18}$ Montes Graciela (2001). La frontera indómita. México; Fondo de Cultura Económica, p. 25 


\section{BIBLIOGRAFÍA}

Auster Paul (1994). La invención de la soledad. México; Anagrama.

Cacciatore Joanne. Caleidoscopio del duelo (trad. Carla Roel de Hoffman). http://www.missfoundation.org/kids/pdf/caleidoscopio.pdf

Cacciatore Joanne. ¿De qué color es la muerte, papi? http://www.missfoundation.org/kids/pdf/caleidoscopio.pdf

Calvillo Vaillard Aída M. G. (1996). Los niños hospitalizados. México; CNDH.

Cortázar Julio (1974). Historia de cronopios y de famas. Buenos Aires; Minotauro, 9a edición.

Garmendia Julio (s/f). El médico de los muertos. Venezuela; Ediciones Maria di Mase.

Jacob Esther (1987). Así cuentan y juegan en la Huasteca. México; Consejo Nacional de Fomento Educativo.

Jacob Esther y Ramírez Granados, A. (1984). Cuántos cuentos cuentan... México; Consejo Nacional de Fomento Educativo.

Ladrón de Guevara Moisés (1985). La lectura. México; Caballito/SEP.

Mato, Daniel (s/f). Cuentos para hacer muchos cuentos. Venezuela; Ediciones Maria di Mase.

Montes Graciela (2001). La frontera indómita. México; FCE.

Morales Alfonso (1988). El doctor improvisado. Libros del Rincón. México; SEP. 
Perea María Luz y Rosas Moreno José (1985). Fábulas Mexicanas. México; Diana.

SEP (1986). Cuentos de puro susto. Libros del Rincón. México; SEP.

SEP (2006). Ciencias naturales. Libro de texto. Tercer grado (6ta. Reimpresión).

SEP (2005). Libro integrado. Libro de texto. Segundo grado (11a. Reimpresión).

SEP (2006). Lecturas. Libro de texto. Tercer grado (7a. Reimpresión).

Vicencio Álvarez Teresa (1985). "Material de apoyo para los altares". MIMEO. México; SEP.

Zacarías Mari (1992). El muerto todito. (Teatro para niños). México; INBA. 


\section{ÍNDICE}

Introducción $\quad 5$

I. Todo tiene un origen 9

II. Todo lo vivo sigue un ciclo 19

III. Nuestras capacidades como seres vivos 35

IV. La muerte es parte de la vida 53

Anexo 1. Lecturas 69

Anexo 2. Reflexiones 95

$\begin{array}{ll}\text { Bibliografía } & 105\end{array}$ 